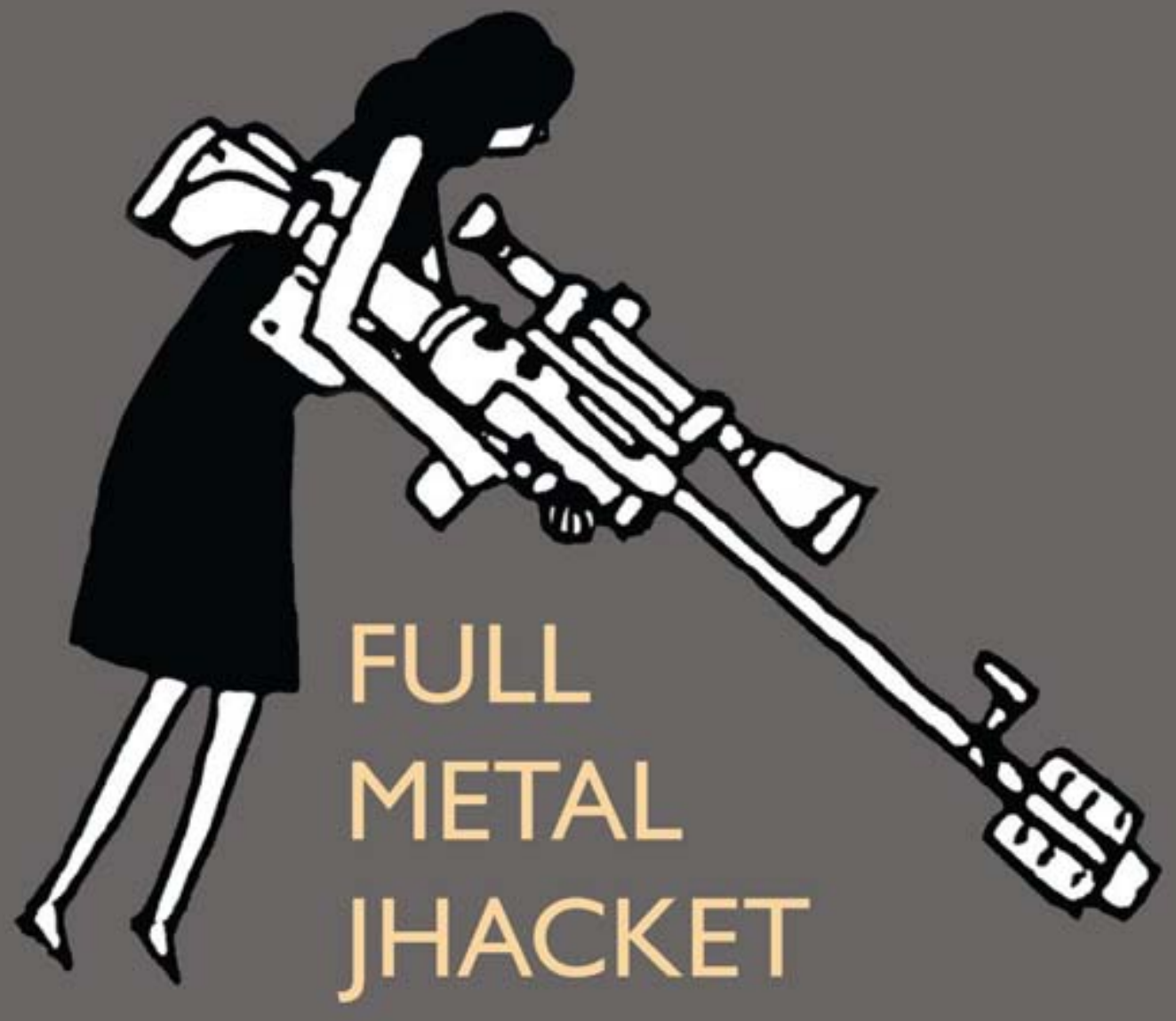

Matthew Derby 
Full Metal Jhacket 



\title{
Full Metal Jhacket
}

\author{
Matthew Derby
}

University of Michigan Press

Ann Arbor 


\section{Copyright $(\mathcal{C} 2015$ by Matthew Derby}

All rights reserved

This book may not be reproduced, in whole or in part, including illustrations, in any form (beyond that copying permitted by Sections 107 and 108 of the U.S. Copyright Law and except by reviewers for the public press), without written permission from the publisher.

Published in the United States of America by the

University of Michigan Press

Manufactured in the United States of America

$\begin{array}{llllllll}2018 & 2017 & 2016 & 2015 & 4 & 3 & 2 & 1\end{array}$

DOI: http://dx.doi.org/10.3998/tfcp.13240730.0001.001

ISBN 978-0-472-03615-8 (paper : alk. paper)

ISBN 978-0-472-12096-3 (e-book) 
For William Derby 



\section{Contents}

Acknowledgments

ix

1. January in December 1

2. Dokken 18

3. The Snipe 29

4. Full Metal Jhacket 46

5. The Past, Uncorrected 68

6. Thirty Years of Prosperity for Every Fifteen Years of 79 Hard Work

7. Yeti 93

8. How the Rebels Took Port Harcourt 102

9. Heightmap of Her Countenance 117

$\begin{array}{ll}\text { 10. KraftMark } & 127\end{array}$

11. Walden Galleria Prayer 138

Books in the Series 145 



\section{Acknowledgments}

"January in December" originally appeared in Guernica; "The Snipe" originally appeared as a JR Van Sant Chapbook Series selection; "Dokken" and "Heightmap of Her Countenance" originally appeared in Unstuck; "Full Metal Jhacket" originally appeared in The Collagist; "The Past, Uncorrected" originally appeared in Caketrain Journal; "Thirty Years of Prosperity for Every Fifteen Years of Hard Work" originally appeared in The Columbia Journal; "Yeti" originally appeared in Ben Marcus's Smallwork; "How The Rebels Took Port Harcourt" originally appeared in The Columbia Journal; "KraftMark" originally appeared in The Apocalypse Reader anthology; and "Walden Galleria Prayer" originally appeared in The Book of Uncommon Prayer anthology. 



\section{January in December}

Church was bunk. Scarves were bunk. The cold was bunk. Robert Fancer's grandfather, the man he was wheeling back from afternoon service in a crappy chair, was massively bunk. There wasn't a word for the level of bunk Fancer's grandfather was. Especially when the wheels of the chair were coated in brown gritty slush, like they were just then, on the way back from the church, and the grandfather was trying to tell him shortcuts that didn't even exist anymore, places that had been bricked up years before or fenced in or protected by loud dogs, and his grandfather smelled and was losing his mind and he apologized even though he didn't mean to apologize, even when he was trying to do the opposite of apologizing underneath the apology.

"If you had turned down that alley, we'd be home by now," he said, pounding his fists against his thighs.

"That wasn't an alley. That was a newsstand."

"I'm sorry about that, Robert. But if there was an alley there, and there should be, we would be home."

Before, Fancer's mother had taken care of everything-the catheter, the vinyl sheets, the runny bowels-all of the horrible things that happened to Fancer's grandfather in the course of a day. She executed these tasks with such precision that they attained a transparency. It was only through the yellowed lens of her death that Fancer saw how profound her influence was over the apartment, how much discord had been held back by her fierce, silent vigilance. She was dead and he could no longer pay for the Pakistani nurse to come, the one with the fantasy name he couldn't even pronounce whose voice was thin and sweet, always on the verge of song. She would come once in the morning and again in the afternoon and when she came the second time her voice was always lower, as if weighted down. Fancer missed the nurse. He felt a pitted longing for the wind she carried through the house, the brief flurry that stirred the still, dim rooms, sheets snapping and halving under the direction of her sure hands as she stood next to his grandfather's bed. Fancer wanted to ask her where she had learned to do these things with such dispassion, under 
what circumstances she had happened into this part of the world tending to the small brown apartment he shared with his grandfather, which seemed a profound disgrace. He wanted most of all to hear the voice, to drape it over himself like a shawl, but he could barely muster speech in the presence of the nurse, and so he never asked, just left the money in an envelope on the small table by the front door and waited for her to leave. Then he got fired from the supermarket for crashing a delivery truck packed with snack cakes and his grandfather's pension was barely enough for them to keep hold of the apartment. He called the agency that sent the nurse, asking for a temporary extension of credit, but they did not do credit, they were a cash-only establishment.

Fancer and his grandfather made it back to the apartment building. Fancer bent down and hefted the old man, who weighed less than a stick, onto his back. This was the only way they could get up the stairs because the chair would wobble when he tried to lug it up backwards and Fancer worried something would break or that he'd lose his grip on the rubber handles and his grandfather would tumble down the long narrow flight, his bones snapping like kindling.

"You're good for doing this, for making sure I get to mass," Fancer's grandfather said, clinging to him with feathery arms. "I'm very thankful. Do I seem thankful to you?"

"Yes."

"I want to make sure you know I am thankful. I was never thankful, not to your mother or to your grandmother before her. They both died resenting me. I know it."

"They did not. It's fine."

"That's nice of you, Robert. But I can tell. I can feel it. I can feel them looking down from heaven. I can feel the pressure of their eyes above me, bearing down."

Fancer carried his grandfather into the apartment, laid him out on the special bed, covered him in a crocheted afghan, and turned on the news. The first story involved a group of nuns who had been raped and murdered by soldiers in El Salvador. Father Gregory had mentioned the women in his homily. He told the congregation to turn their anger into prayer because the sentiment would multiply like the loaves and fishes and spread out into the world in the form of peace. After the story about the nuns the news anchors talked about the hostages in Iran, a warehouse full of abused cats that had been discovered in White Plains, a new advance in heart medicine, and the Dallas Cowboys. The male anchor made a joke about the Dallas Cowboy cheerleaders at the expense 
of the female anchor. The female anchor laughed, concealing a grimace, and the news ended.

"Why didn't they mention the election? When does the election happen?" Fancer's grandfather asked, clicking laboriously through the channels, which were mostly jagged bands of static. The wand worked only intermittently and only when you rolled the batteries back and forth while clicking. Mostly they kept it on the same station and hoped.

"Grand-dad, come on. Already happened."

The grandfather stopped clicking. "You're serious."

"Yes. You saw it."

"Who won?"

"Come on, Grand-dad. Reagan won. You know this."

"Oh, god. I hate this head. It won't work." The grandfather blinked and scrubbed a veinous hand over his scalp, smacking with his elbow a Tupperware bowl full of unpopped and half-popped corn kernels left over from the day before.

Fancer knelt on the floor and began picking the oily kernels out of the carpet pile.

"I'm sorry, Robert. About the mess I've made. Not just there, the mess on the floor. I mean the mess inside me. I hate when that happens, when I forget."

"It's fine."

"But I really am sorry. You can't understand what it's like. I have these huge holes in my head where all of the memory goes. Like down a drain. Do you understand?"

Fancer paused, crouched on his elbows and knees. "Stop apologizing, please."

"But I want you to know. My life is going away, slowly, down these holes."

"Please stop. That's what happens. There's nothing to apologize for."

"Don't let your life fall away from you like this. It's pathetic."

"Stop it."

"When you're done with that, could you bend the TV over this way more? That yellow spot-the reflection from the hall light-is making it hard to see."

Fancer moved the television for his grandfather. On the program there was a detective investigating an assassination. He wore a thick moustache and rubbed his chin vigorously, pointing with his free hand at a crumbling apartment building across the street. It looked like Fancer's neighborhood, but no building he recognized specifically.

"How much longer do I have to stay awake today?" 
"You don't have to stay awake."

"Be good and bring me some of the drink."

"When it gets to commercials," Fancer said, but he went to the kitchen anyway because he knew he wouldn't be able to bear sitting through the detective program while his grandfather stewed in the special bed. He went to the refrigerator and mixed some vodka into a tall glass of orange juice. He handed the drink to his grandfather, who began immediately slurping away the pulp from the surface like a young boy. Soon his attention drifted back to the television.

Fancer retreated gingerly to his bedroom and lay down on his stomach on the bed. He reached under the bed for the long red box and dragged it out so he could see it. He opened the box and looked at the Kalashnikov. It looked mean, like a dragon's tooth with a trigger and a stock. He lifted it from the fitted case. It was freezing cold in his hand. He breathed on it, which only made it wet. The people's rifle. He put it back into the case. He sometimes bought weapons for Craig, who couldn't buy them himself since he was arrested that time in Queens. Craig would be coming for the Kalshnikov soon. Fancer wondered what it would take to convince Craig to let him keep it. He thought about the rifle constantly. Its presence in his room forced a clarity to erupt through the measured torpor of his life; it revealed, for the first time in years, a sense of purpose. He wanted to use it for something big, something that only big people did, the ones who took up huge chunks of the world, crowding out everybody else. He was ready for it-he'd compressed and sharpened his years of isolation into a jagged courage. He just needed a target.

The bell rang. Fancer's son, Thuan, was at the door, holding a paper bag with his things. Fancer had made the boy with a captured Vietnamese resistance fighter named Binh, whom he'd guarded at the prison camp in Bien Hoa. Binh tailored shirts in a factory and was addicted to some sort of diet pills that were actually really high-quality speed and she was across the street at the bus stop reading a magazine. Thuan was named after Hai Thuan, who was someone important to the Vietcong. Thuan, the boy, had happened to Fancer and Binh after a lengthy, botched interrogation session. The investigator could not get any useful information out of her. He wiped his face with a thin, stiff towel and threw it at Fancer's neck before leaving the room, disgusted. Binh huddled in a corner, panting, her wrists and fingertips browned with dried, crusted blood. When Fancer went to pick her up she fell into his arms, a motion he interpreted as a sort of resigned, fatigued passion. A few days later, she was 
removed in a prisoner exchange, so that Fancer didn't find out about his son until 1977 when she tracked him down in Harlem. He remembered little about the morning Thuan was conceived, just that Binh mumbled in slushy fractured sentences and that one of her arms was just barely shorter than the other. There was a mustiness to her, a robust and impermeable scent like a soiled wool coat. It was the scent of prison, of communism. She glowed in the shady periphery of the windowless interrogation chamber and when he embraced her it was partially to shut out the light that seemed to emanate from her naked torso.

"Hey," Fancer said.

The boy looked up and said something that sounded like "google."

Both of them watched Binh get on the bus and take a seat toward the back. Binh was the boy's mother but Fancer was only Fancer, despite a series of early attempts to bore his way into the boy's world. Binh brought Thuan out to him whenever she needed to be in the city. The bell would ring and Fancer would hurry down the steps to the front where the boy always stood holding a paper bag with his things.

"Can I have a cigarette?" the boy asked.

"How old are you now?"

"Ten."

"That seems too young to smoke."

"It's not."

"Let me think about it."

The boy opened his bag and carefully removed a crumpled pack of cigarettes. "I will hold these while you think about it."

"What do you want to do today?" Fancer asked.

"Just play video games."

"Okay."

They walked three blocks to a narrow, poorly heated arcade. On the way the boy slid a flattened cigarette from the pack and lit it.

"I didn't say you could have that," Fancer said.

"I get tired of waiting."

"Could you put it away? It looks wrong."

"What does?" The boy held the cigarette expertly between his forefinger and middle finger and when he exhaled he blew the smoke discreetly away from Fancer. The boy had a point-he looked oddly mature. Fancer had stopped smoking when his mother died, mostly out of respect since it was the peachsized tumor in her throat that killed her. But he hated to quit and thought often about the sweet burning in his mouth, the light, drowning sensation. 
"You just look too small to be doing that. People are staring at us."

The boy did not respond, just took a long drag and exhaled through his nose.

At the arcade Fancer changed a five-dollar bill for a handful of quarters. The boy made it through seven levels of Galaxian on a single quarter. Fancer didn't really know how the game was played but the boy commanded the furious pixels with such exactitude and determination, immobile except for the pair of synchronous spastic hands, that he felt his heart rise up against the walls of his chest.

Afterward they bought wet, translucent fries from a Middle Eastern man on the street and ate them in a vacant lot where four girls were trying to jump rope with a partially unthreaded telephone wire.

"How did you learn how to play those games?" Fancer asked the boy, who was sitting on his hands to warm them.

"I don't know. I just tried them."

"I try those games sometimes," Fancer said. "I always die right away."

The boy nodded, staring into his lap. "You're older."

"Maybe, you know, you could teach me how."

Thuan didn't answer, just fished for something in his jacket pocket. $\mathrm{He}$ looked uncomfortable.

"How is school?"

"It's just school."

"Any bullies?"

"What's that?"

"Kids who mess with you. Push you down. Call you names. Like that."

Thuan shook his head slowly, as if unsure.

"Anybody there that you just wish you could take out?" Fancer said, rolling a charred pebble around on the blacktop with his heel.

The boy, smoking again, inhaled and just held the smoke inside, like he was trying to store it for later. "You mean who I would kill? That kind of thing?"

"Yeah."

"Why you asking me this again?"

"I've asked you this?"

"You ask every time I come."

"Oh. Shit, sorry." Fancer slid his hands between his thighs. He could feel his cheeks going sour and red.

"You don't remember things."

"I said I was sorry." 
"Can we go somewhere else now?"

There were many things in Fancer's life that he did not like. Being told by someone he had taken part in creating that they knew more about him than he himself knew was maybe the thing he hated most. It made him want to get up and leave the boy there on the park bench. He wanted to walk away forever, to escape the city, to lose himself in a thick forest somewhere. It would be a glowing place, and he would walk barefoot and feed deer from his cupped palm, and he would no longer have to change the fetid bedsheets of his grandfather or listen to a small boy he loved tear him down on the small, rippled half-circle of cracked pavement behind the arcade, crisp sunlight flashing brilliantly in the mounds of dry snow.

They walked down to Central Park in silence, the boy taking the lead, tapping things with a twig he'd torn from a tree. It was too cold to walk, and way too far, but Fancer didn't want to spend money on bus fare and anyway they had a whole day to get through.

Thuan started walking with his eyes closed. "Hey," he called back to Fancer. "You tell me if I'm about to hit something."

Fancer closed his eyes as well. He could only get four or five steps before chickening out. Then he started to walk with his head pointed straight up. He craned his neck back so far that he could see the tops of the buildings. He wondered how far the Kalashnikov could fire. He wondered if it could hit a target at the top of the tallest skyscraper. Peg a guy off the top of the north tower. A feverish urge to smile cascaded through his insides, but he did not smile, just cued the laugh track inside his chest while a smaller version of himself mugged and took a bow in front of a studio audience.

Up ahead he saw a very well-known singer signing an album cover for a young woman on the sidewalk outside an old stone hotel. The singer was someone Fancer had admired for many years, as far back as he could remember. Fancer considered the singer a top-notch performer, maybe the best in the world. He looked hard at the singer for a long time to make sure he was right. There was no question-it was the same narrow, hook-nosed face he'd pored over on album covers and promotional posters for years. The voice that streamed through the bunk radio at midnight in Bien Hoa.

"Hey," he said, rushing up behind Thuan, poking him gently. "Look there -it's..."

Thuan squinted. "I don't know who that is."

"Come on, sure you do."

"No." 
Fancer had followed the singer's career for many years, had even seen him perform once at Madison Square Garden. Fancer was twenty-four at the time. He hadn't been back in the United States for very long. He still felt, at night, the dizzying claustrophobia of the jungle canopy as he lay absolutely still on the grandfather's sagging old bed. The singer had changed greatly from the well-dressed young man Fancer remembered from his adolescence. He had grown his hair long, and mockingly wore fatigues onstage. But his performance at the Garden made Fancer feel something he couldn't explain-a giddy trembling at the back of his head, right at the base of his neck, something he had never felt anywhere else at any other time.

The singer's hair was short again, and he wore a white T-shirt beneath a faded denim jacket, an outfit that seemed outrageously unseasonable. The young woman, whose dark pageboy cut accentuated a punchbowl face, was wearing some sort of gingham peasant skirt. Her brow was furrowed in concentration as though she were working very hard to record every detail of the transaction-each word the singer spoke to her a separate parcel to be numbered and shelved. Each brief, hysterical reflective streak in the record's shimmering plastic wrap to be drawn and redrawn later in some sacred headspace.

He was close enough for her to touch.

It felt as if the moment had been hovering there in the future all along, waiting for Fancer to find it. It was like a note someone had written to him-a note or a set of instructions, a document that would be revealed to him only when he was ready to receive it. Maybe someone had written it there on the night that Fancer had seen the singer walk out onto the stage, dwarfed by the cacophonous rioting of the young people in the aisles, or maybe even since the day Fancer was born. Maybe the moment formed as he exited his mother's womb, crystallizing in whatever city the future is stored, just waiting for him to stumble upon it and find the anchor point for his life's trajectory, to recognize the truth-that when he did the big thing-when he carried out the detailed plan that was slowly unfurling inside his head-the rifle would come apart into a million pieces in his hand and inside would be a small pure song, like a bead of light.

When they got home Fancer's grandfather was on the floor sleeping. He was holding a plastic jug of Magic Shell ice cream topping. He'd been drinking it straight from the bottle.

"What the-hey, get up off the floor," Fancer shouted, swiping the container from the old man's hand. The grandfather opened his eyes briefly and then shut them again. 
Thuan went into Fancer's bedroom and closed the door.

"Hey," Fancer said, giving his grandfather a sharp, restrained kick in the thigh. "I mean it. I'm done picking you up after you've done something you're not supposed to. You got to learn to stop that."

The grandfather opened his eyes again but did not look at Fancer.

"My kid saw this. My son saw this. How am I supposed to explain this to him?" Fancer bent down and lifted his grandfather back on the bed.

The grandfather rested his forehead against the metal bars on the side of the bed, the ones that were there to keep him inside. "I'm sorry," he said, and closed his eyes again.

Fancer went into the kitchen and riffled aggressively through the cabinets looking for a meal that the boy would eat. There was nothing he could combine to make a full meal so he broke off a hunk of frozen peas and ate it over the sink. On the radio on top of the refrigerator someone was talking about the raped, dead nuns. There was an interview clip of one of the family members, a father who sobbed incomprehensibly. Then a song came on, a song by the singer, and Fancer stopped crunching the brick of peas to listen. He remembered how close he had just been to the singer; that the singer was, right then, moping around in the same air mass, moving objects around in the same city. The coincidence of the sighting and the song rose up sharply inside Fancer. It was possible, suddenly, to see the two separate incidents as the interlocked hemispheres of a vast, shadowy world in which he found himself increasingly entangled.

"Hey," his grandfather called from the next room. "Turn off the radio and come in here. I haven't seen you all day. Where did you go? I was calling for you. And why did you try to kill me? You almost killed me with that jug of syrup."

"You drank the syrup."

"Come here and tell me what happened today. Bring the boy."

Fancer let the shard of frozen peas fall into the sink, where it shattered and slid in wet chunks down the disposal.

"What was that?" his grandfather called out.

"Nothing. Peas."

"Peas?"

Fancer opened the door to his bedroom. Thuan was already lying on the floor, setting up a tiny group of articulated plastic figures on the burgundy shag rug. 
"Do you want to watch TV?" he asked, leaning over the threshold, one hand on the knob.

The boy shook his head and reached in the bag for a vehicle.

"Your grandfather wants to see you."

Thuan continued to move the figures around on the floor.

Fancer went into the TV room and turned on the set.

"Leave that," said the grandfather.

"No."

"You're going to tell your grandfather what you did today, so turn that thing off."

"No way. The Muppets are going to be on."

The grandfather fell back against the pillow and let his head roll back and forth a little. His mouth was still ringed with half-dried Magic Shell syrup. "To think that a boy would sooner watch a puppet than tell his own grandfather about the world. It's horrible. I've been stuck in here all day, imprisoned in this damn -" and then he stopped, aware that Fancer was no longer listening to him.

The woman slipped the magazine into a plain brown bag and slid it toward Fancer, purposefully avoiding eye contact. Fancer had been out for most of the afternoon, looking for "help wanted" signs in shop windows, sipping dry, rancid coffee, paging through monthly magazines in store after store, picking up bits of stray newspapers left on half-smashed benches, anything to destroy the empty hours of the day. He'd seen the magazine behind the counter, the magazine with an exclusive interview with the singer, and, even though it was a dirty magazine, even though he was blowing lunch money for the next couple days, he'd weathered the embarrassment of the purchase for a chance to read what the singer had to say for himself.

He walked for a long time before finding a busted toy kitchenette behind a dumpster where he could read the article without being seen. He drew the magazine slowly from the bag. "January 1981" it said, even though it was only December. This was a startling, liberating impossibility. The future-a month Fancer hadn't even lived through yet-had already been documented. The future was known. All Fancer had to do was follow the path that was already in front of him.

He hunched forward on the flimsy plastic furniture, which collapsed slowly under his weight. There was a half-famous actress on the cover, dressed in a tattered nylon outfit, but Fancer was not interested in the woman or her body. 
He skipped straight through to the feature on the singer. The interview went on for many pages. Fancer read each of the singer's responses carefully, fingering each line of text even though his hands ached from the cold. He didn't want to miss anything. He knew it was ridiculous, but he kept sensing that the singer might suddenly mention his name; that, somehow, he had been on the singer's mind as much as the singer had been on his. As he read, the probability of this increased, until, at the end, it seemed inevitable, so that when he was not mentioned he felt belittled and cheated.

He chucked the magazine under the lid of the dumpster and started erratically down the street, no longer sure where he was, in search of a pay phone.

"Hey, is this Craig?" Fancer said softly into the receiver.

"That you, Bobby?"

Craig was someone Fancer had met on the way back from the war. He was just a person who talked too much on the plane, who kept writing letters to Fancer after they landed. He worked for a company that was trying to get computers small enough to fit in a house, and sometimes when he was in the city for a convention they went to bars together. He also liked rare weapons. He'd send Fancer a package that had directions to a grayed tenement rubberbanded to a cigar box stuffed with bills. Craig needed the weapons, he told Fancer, because they were like a bridge between the two parts of his life he no longer cared about, the before and the after.

"I was wondering-that thing you had me get you, right?"

"Yeah. I said I would be by tonight to pick it up, didn't I?"

"Yeah. I was wondering, actually, if I could keep it for a while longer."

"No way."

"Can I, like, rent it from you?"

"No man. That is a Soviet piece. Pro-grade. Totally impossible to come by. Do you know how hard that was to get? Way hard."

"Just-how long will you be in town?"

"Three days."

"Okay. Can I just-can I keep it until then?"

"Man, I kind of have to think about that. I don't feel right about it." "Please."

There was a sound like glass breaking on the other end of the line. Then a girl laughing, talking in another language. "Hey," Craig said, finally. "I sort of have to go. Can you meet me at the car rental place the day after tomorrow?" "Yes."

"Okay. You can keep it 'til then." 
Fancer opened his eyes without moving the rest of his body. Just opened his eyes and, without blinking, looked at the ceiling, trying to figure out what the scratching sound was. He listened to it until it turned into something else, a faint, ancient voice, telling him he had no more time to waste. He had only hours left before he had to meet Craig-so few he could taste them each individually, like they were spice drops. Anxiety welled inside him and seeped painfully from every pore.

He sat up in his bed. Thuan was asleep on the floor next to him, half off the foam mat. The noise became more pronounced. It was erratic, desperate-it came from another room.

"Hello?"

He opened his door. He could see, down the short hallway into the TV room, the grandfather's feet, crossed one over the other, like a dead bird.

"No," he said. "Please not today."

The grandfather was stretched out on the floor trembling, one arm extended underneath the emerald recliner next to his bed. His eyes were mashed shut. Fancer knelt and rolled him over onto his back. His face was all wrong, like the flesh had come loose from the sinews or ligaments or whatever kept skin tight against the skull. His lips were wet and rubbery and a little bluish. The scraping sound was the grandfather's fingernails against the cardboard underside of the recliner.

Fancer went back to his bedroom. Thuan was sitting cross-legged on the floor, his eyes thick with sleep.

"Hey, Pop-Pop's really sick. We have to go to the hospital right now."

"Okay."

"I have to call an ambulance or something. I need to think about what I'm supposed to do."

"Okay."

"But don't get alarmed or anything. Just hang out in here. Just stay here until I come back in and say it's okay. Okay?”

Thuan sat down on the bed, resting his bag next to him.

Fancer walked Thuan over to the area the emergency room attendant had motioned to, a bench of fused orange plastic chairs next to a vending machine that sold hot drinks. They sat at opposite ends, Thuan leaning against the machine with his eyes closed, steam from the photograph of hot coffee seeming to rise directly out of his small head. 
They waited for a long time. It was impossible for Fancer to tell how long because from where they were sitting they could not see the single wall clock mounted behind the help desk and there were no other indicators of the passage of time anywhere. Just a loose group of people waiting, splayed out on identical chairs, some bloodied, others just shaking or silently wailing in slow motion. It was almost like there was no time happening at all. It was as if he and the boy were fixed in a diorama lit by fluorescent tubes, just sitting there outside time.

A young man with feathered hair emerged with a clipboard. He told them they needed to run another battery of tests.

"Can you give me a ballpark figure of how long it will take?" Fancer asked, chewing at a hard, pebble-sized lump on the inside of his cheek.

"Sorry, not at this time."

"Do I-that is, would I have time to run some errands while you do this-these tests?"

The attendant looked hard at Fancer. "Please stay close, in case things get worse-not that they will get worse, but-just, it would help all of us if you could stick around."

Fancer sat down next to Thuan.

"What did they say?" the boy asked.

"Nothing. They don't know anything. They're doing more tests." "Oh."

Fancer crossed his arms and bent over, resting his forehead on his knees. He pursed his eyes shut until he saw colors. Then he whipped back, making himself dizzy.

"I have to go out for a few minutes."

Thuan stood up, zipping his coat.

"No, I need to go by myself."

"I'm going to stay here?"

"They might have news about Pop-Pop." Fancer took a brief survey of the room to see if anyone was listening.

"I don't want to stay here."

"You'll be fine. It's safe here. That's why it's called a hospital."

He held the boy's head in his hands and kissed his forehead.

"Be good," he said, and handed over a one-dollar bill and some change.

He took a cab back to the grandfather's apartment, using the money he'd saved in his breast pocket specifically for the plan. The dark outside was startling, or maybe it just felt so oppressive because Fancer had been in the bright 
hospital waiting room for so long. Looking out the smudged window of the cab he saw only the occasional flare of a neon sign between the black buildings and trees.

"When we get to my apartment can you wait outside and then take me someplace else?" he asked, hunching over in the seat. Fancer had never asked this of a cab driver before but he'd seen it done in the pictures. The driver made an indecisive motion with his head and shoulders, one that told Fancer nothing and discouraged him from asking any further questions.

The driver pulled up in front of the grandfather's apartment. Fancer sprinted up the concrete steps, winding himself by the time he made it to the door. A load of something hot and sharp balled in the back of his throat as he turned the key in the lock, a mucosal clot that tasted like relief or shame or both together, vying for a spotlight in his head. He was close enough to the plan now to feel its heat. It was a real thing surging through him, coursing through his blood, looking for a way out.

The floor in the hallway was scuffed and splintered from when Fancer and Thuan had hurriedly dragged the grandfather out to the stairwell. This was what the investigators would see afterward, he thought. These rooms would be photographed, samples would be taken, evidence collected. Detectives standing in the crowded corridor, their faces simplified in the newsprint ink, an image that would streak its way into the future, outliving everyone and everything.

He entered his darkened bedroom the way a stranger would-cautiously, one foot touching down delicately in front of the other, sliding his hand along the wall to search for the light switch. Lit from above by a single bulb, it looked like a room someone went to do something illegal. He squatted before the bed and yanked out the red box. Taped on top was a sheet of ruled paper. On it, the boy had written in smudged, boxy script, "IS THIS FOR REAL? Please check one: Yes; No." He folded the paper and put it in his pocket.

Fancer rushed down the steps, hugging the red box with both arms. The driver was standing beside the running cab with his legs crossed, tamping a pack of cigarettes repeatedly on his thigh, and he slowly dropped his head as Fancer approached the cab to amplify his disinterest. Fancer finally saw the man's moon-shaped face in full. Each of his features mirrored the spherical contours of his head-round, heavy-lidded eyes, round mouth and lips, rounded nostrils.

They entered the cab without speaking. Fancer sat up straight in his seat, the red box in his lap, his hands resting evenly on its surface.

They had to stop often for red lights. Fancer watched the pedestrians swarm 
around the cab, toting holiday gifts in thick paper bags. Soon they would know him, would understand the cosmic necessity behind the thing he was about to do, and never forget his face.

At Seventy-second Street, the driver tapped the brakes. Fancer's heart slowed suddenly, cooled to a low, even drone as he recognized the spot where he'd seen the singer that day with Thuan.

He had the driver pull up across the street from the singer's hotel near a stand of well-trimmed bushes. He squatted over a patch of dirt that had been worried to a porcelain sheen by sleeping bums. He opened the box and assembled the Kalashnikov in the amber half-light cast by the streetlamps. He was cool and efficient, his hands steady in their work, just the way he'd practiced.

Cars passed on the street. A well-dressed older couple walked quickly by, pretending not to notice Fancer's head peeking over the brush. He didn't care if he was seen. Better, he thought, if he was seen. He imagined the couple the next morning, the woman briskly unfolding the paper, reading the account, asking her husband whether he remembered the funny-looking man in the bushes, the one with the lopsided head and small, pointed eyes, working on something made of metal.

The cold began to wear at him. His toes stung inside his useless, flattened combat boots. He longed for a meal. He thought about the dollar he had given his son. He hoped the boy was eating, or blowing on a waxed paper cup of piping hot chocolate. He hoped a nurse would come and take pity on the boy, maybe play a game with him while they waited for someone to come along and claim him. Maybe, when no one came, the boy would end up with people who could actually take care of him. He imagined the couple who'd just passed by-they would read about the abandoned boy in the newspaper and feel vaguely responsible for his welfare. They'd adopt the boy, move him out to a well-appointed neighborhood far from the city, a green and iridescent place peopled with helpful, friendly neighbors, the aisles of the supermarkets stacked with fresh produce glistening with beads of moisture from the automatic mister. Someone, Fancer decided, would love the boy fiercely, teach him actual, like, things. Maybe, then, Fancer, crouching in the bushes, waiting to kill a person he'd never even met, was putting the final touches on his only fatherly gesture.

A long black car pulled up in front of the hotel. Fancer knelt, just the way he had remembered, and shouldered the weapon. He saw the singer's wife emerge from the car and then the singer himself, wearing the same outfit as before. He traced their movement through the reticule. Everything inside him tightened. 
When he heard the first shot, Fancer thought he'd pulled the trigger himself, though there was no heat or kickback. Across the street he saw a man in a dark overcoat braced in combat position, holding a pistol. Fancer had seen the man earlier, loitering outside the hotel, reading a paperback book. As he brought the man into focus, Fancer saw the barrel of the gun burst through the night four more times. Ahead of him on the sidewalk, the singer was sprinting erratically, waving his arms, followed by his wife, whose mouth gaped in an awful rictus. Fancer could hear the singer making gurgling sounds like a loud balloon losing air underwater. The singer somehow made it inside the hotel before collapsing, his ruined back dark with blood. The singer's wife threw herself on top of him, covering him with her body. Sound started to come out of her mouth, a tight, high-pitched tone, ribbon-thin. Fancer looked back at the man on the sidewalk, who stood under a street lamp, lifting one hand and then dropping it again, as if unsure what to do next. Then he removed his hat and overcoat and threw them into the bushes. The hotel's doorman appeared. He approached the man without a coat. "Do you know what you've done?" he shouted, again and again, as if calling out into the wilderness, while the man tittered like a goofy adolescent and shuffled backwards, leaning against the brick hotel wall.

Fancer set the rifle down on a mound of hard snow and rose slowly, the street lamps illuminating his lower half in dishwater light. He had failed to put into motion even this, his last attempt to push something back out into the world instead of taking it, once again, in. If he had been a better man, a more reasonable man, hardened by life instead of merely weakened by it-if he had been a man who planned out a day instead of mincing his way through, bitching out the hours one by one until they disappeared up the steel column of night, he might have made something of the moment, put his signature on it. He might have set a special, public fire. But this other man beat him to it. He felt a clean tremor of recognition-clean because it was like the wispy white center of an ice cube-at what the man across the street had done, what he had failed to do himself. The man had cut a hole in the history of the world, and fallen in, and Fancer was standing at the freshly torn edge, peering down.

The police came and surrounded the man, and he did not resist. They led him away to a squad car that was hastily parked halfway on the curb. The man lay down in the back seat, hiding from the officers and bystanders that surrounded the car, but Fancer could swear he saw the man's terrified smile still hanging in the place he'd just been standing, burned into the night air, the way you could see, on the evening news, ghostly white trails from the flashlights of the search crew in El Salvador, examining the site where the nuns had been killed-a bright reminder of the video camera's shortcomings, an impression of the world as created by a faulty, primitive 
system. Fancer stared hard at the smile, blinking against the chill, trying to wipe it from his vision. The mouth opened then and seemed to say, "There is nothing left to do with a life but wait." It was nonsense-there was no mouth. There were no words. It was just a failure of the senses, an illusion, a string of garbage that became something else, something real and heavy as it took shape before him, staining his eyes for good. 


\section{Dokken}

The weight loss came first and was easiest to explain away. Taichea and I are alone on the gyre with only the air-dropped cache of non-perishables to share between us, so it follows that I would thin out over time. The fatigue, I could effortlessly attribute to the lack of food as well. The chronic nausea was surely nothing more than a bug, a wayfaring flu virus that blew in from the South China Sea, and the night sweats? We are living on a solid mass of trash twice the size of the United States-who knows what sort of fumes we're inhaling? The restless breeze that wafts over Bisphenol Beach leaves a sour tang in our mouths-who can say for sure what it's doing to our bodies? But the blotched sores that bloomed on my neck like the bite marks of some creature attempting to dine on my soul-those marks were unmistakable to Taichea. The same spots had taken her grandfather and made a brittle wisp of her mother. There was no hiding what I'd come down with anymore and that is when everything started to really take a turn for the worse because there was a baby growing inside Taichea to whom I'd most likely passed the thing I'd contracted, and for all we knew it could be the last human baby gestating in anyone's womb anywhere.

"How long have you known about this?" she said, sitting bolt upright next to me in the dome tent. It was early morning. I snapped open my eyes to see her staring evenly at me in the blurry predawn light.

"About what?" I said even though I had a feeling.

"Take a look at your neck before you say anything else." She coolly offered the hand mirror. I had never seen her upset in quite this way before. I took the mirror and examined the spots, gingerly brushing them with my index finger. Faint beet-hued stains arrayed like a map from my adam's apple down to my sternum. They were called sarcomas, weren't they? This was not a thing that happened to people anymore. HIV was an antique virus that I knew only through folklore and the agonizing 2-D grade school seminars I'd endured in my youth. Xytomitol had effectively put it in the company of smallpox and 
polio and those other diseases contained in test tubes under a mountain somewhere.

"How could you let this happen?"

"You make it sound like something I planned." I set the mirror down on the Mexican blanket that was our sole article of bedding and stared through the netted skylight of the dome tent.

"And?"

And I knew exactly how it happened. Taichea and I had just parachuted down to the landmass with all of our belongings, about forty kilometers down the shore from our present location in the dome tent underneath the sheltering wing of a crashed drone bomber. I unbuckled the chute, kicked off my goatskin loafers, and tear-assed down the length of the beach in a sort of victory run. It was an impulse thing and I just went with it. Took long whupping strides through the polymer turf, huffing the malted sea air. I'd spent my career battling the public perception of the gyre and so it was not without a modest surge of righteousness that I enjoyed the authenticity of the beach moment. It had all of the pulpy immediacy of the standard sand beach, with uncompromising visuals and all of the baseline tactile features. Pundits routinely made a fuss about the profundity of colored nurdles that made up the surface of the beach, those preproduction pellets that were the core resource in the plastic economy and which, when dumped into the sea by a cargo ship or a production plant with excess inventory, were drawn to the whorling landmass of the gyre like metal shavings to an electromagnet. The nurdles are slightly larger in size than the standard grain of sand but they give underfoot with a pleasing little squeal that is its own distinct wonderment and this is why I think people never really got comfortable with plastics-they would not allow themselves to fully enjoy the material for what it is. A plastic beach is still a beach. A plastic palm tree gives as much shade as a wild monocot. I think that the comparative immortality of plastics made people anxious and depressed and just generally distrustful of the stuff, which is a shame.

Mixed in with the nurdles are, of course, the broken-down fragments of a billion plastic bottles and jugs, children's toy bricks and gag hats, handsoap dispensers and laptop shells, diaper loaves and prophylactic errata and all of the foam and bubblewrap and bagging materials that had once swaddled the discarded products. There is, too, the occasional crazed and unidentifiable chassis of a thing that hasn't yet broken down and is sticking half out of the polymer dune. And you're going to sometimes come across some other materials such as glass or metal, sometimes insanely sharp objects made of metal with 
one purpose in life, which is to pierce human flesh. Some of which are needles that have been used by a sullen junkie somewhere, used once or maybe multiple times, or who knows, maybe shared by many men and women as they slumped on frayed couches in darkened, hushed warehouses. Some of which or-let's stop talking in generalizations here-one of which has been shared liberally among the denizens of some abandoned office building and then cast into the sea like a bottle that held a desperate message.

I was running a victory lap because I owned the beach and the hills and valleys beyond. The entire landmass atop the gyre was mine. I had to buy the thing; it was an industry-standard power play in the guise of a PR campaign. Rod Watkins at GenDyne had just purchased an intimidatingly vast stretch of land in Nigeria, where those hacks got the bulk of their raw materials, and he financed the construction of a stadium for whatever sport they enjoyed in that country. Using indigenous labor, empowering the local economy, et cetera. Hitting all the sweet spots. It was one of those airtight campaigns, ruthlessly conceived and executed, that puts everyone else in a bad light. GenDyne's ad agency produced some admittedly great footage of black children kicking a ball in a dead field that gave way through some convincing CGI to a clean, well-illuminated stadium at night where the children, slightly older, competed in slow motion while their parents cheered tearfully from the sidelines. We had no such record of service at United Polymer, which made us suddenly look like greedy monsters. History isn't made by limpdicks so I bought the North Pacific gyre, the whole shot, and vowed to make the continent of floating debris at its center my permanent residence. Demonstrating to the public that the gyre's landmass was an inhabitable surface was the low-hanging fruit; I was already thinking ahead to the bustling triple-A resorts and theme parks that the landmass would support in coming decades. With a satellite dish and a solar panel I could pretty much run United Polymer from anywhere, and I felt it in my marrow that if I didn't take action on the gyre someone else would.

Taichea, a thorough and inquisitive recent graduate from Rutgers with skin like sunlight filtered through a liter of Pepsi, was my personal assistant, and it just made sense to bring her along. Now we are something else. It is a relationship that deftly evades any definition I attempt to apply. But there is a child growing in her that is at least half my fault and if I've passed this virus on to either or both of them I'm willing to take on any additional responsibility such a transmission might incur.

I was running on the beach, every inch of it mine to use as I wished. Bought from the UN for just a fraction of a cent per acre in an unprecedented sale that 
was in itself a colossal publicity win. Previously the island of trash had haunted the psychic periphery of consumers across the developed world. Everyone held an occult suspicion that they had somehow played a part in its creation. Those were their cellophane wrappers and deodorant husks and yogurt tubes floating out to the great continent-sized landfill. When I declared ownership of and, by extension, responsibility for the thing, I released them from the burden of guilt. So that even as they derided me in public, calling me the Trash King of Plasticland, they had nothing but breathless admiration for me in the deep silence of their hearts, for I lifted the remorseful scrim that separated them, spiritually, from all of the things they owned and enjoyed.

Running, striding confidently along the beach, my feet festooned with the neon particulate, I was renewed and redeemed. I felt like I could catch a strong breeze and take off in a gliding arc over the landmass, which I decided on a whim to call Dokken, after my father. I felt as if my body had attained a state of Grecian perfection. My mind was afire. I didn't even know what I was going to do with Dokken, but I was spastic with the possibilities. I was COO of the second most successful plastics manufacturer in the world, just a hair's breadth behind GenDyme and Rod Watkins, that bottomfeeding ghoul with his African ball team, but I was gaining on him. I'd rendered his well-financed play for the public's sympathy moot and inert. All that cash he'd spent on the stadium he might as well have saved for the early retirement I was forcing him to take. I was incandescent with power and possibility, and then I put my foot down on the beach and felt a whooshing pang that rippled up through my leg straight into my brain. I went down in a forward roll and hunched fetally by the burgundy surf. The needle was buried to the hilt at a forty-five degree angle just below the ball of my foot. I examined it for a moment, just sort of woozy with amazement at the aggressive depth of the puncture. There was no blood until I slowly unthreaded the sharp from the hole it had made. The spot welled up quickly with blood that ran down the course of my foot, commingling with the clearish gel that smelled faintly of fake cucumber and that held the landmass together. I looked back in the direction from which I'd come to see if Taichea had seen me fall but I was far down the beach. I saw no sign of Taichea or any other people or things. Just the wicked expanse of the gyre spread out for miles and miles.

"So that'swhy you were limping that day," she said.

"Took forever for that thing to heal up." I smiled as I said this, confident it would make a difference.

"You told me you had a leg cramp." 
"Well."

"Why couldn't you just tell me the truth?"

"I thought it was nothing," I said, which sounded more hollow than I'd intended.

"You went ahead and seduced me."

"I thought maybe it was more of a consensual-type thing."

"You came to me. You told me things. You convinced me that we would have a life together."

"Don't we?"

"What kind of life is this?"

"It could still be a happy one." It was the third thing I'd said already that I didn't believe.

"Well, and what are you going to do about this?"

As it turns out I was well prepared to give her an answer because I had turned that very question over again and again in my mind over the previous days and nights after it had become clear to me what I was up against, being a man infected with HIV at the end of civilization floating around on a massive heap of trash with no access to a doctor or meds or even someone to tell me how to die. "We will go," I said. "We will scour the land for some Xytomitol. Surely there's a case of it somewhere. I've seen boxes full of Wellbutrin, Paxil, Erythromycin, Oxycontin. Crates of the stuff half-buried in the substrate. Good as new."

"Did you just say 'substrate'?"

"You can hardly call it dirt."

She shook her head.

"Look. You don't want to go. I can already tell you do not want to go."

"And you think you have the strength to go traipsing all over the place looking for a treatment that might be buried somewhere?"

"I feel pretty good. Surprisingly good."

"So you're going to leave me here?"

"I can't win this, can I? I mean, come with me or stay here. It sounds like I'll be ruining us either way."

She issued a subtonal growl of disgust. Like I was a hair plastered to the back of her throat that she was trying to hack free. She started to walk away from me toward a charred ridge of child-size sport utility vehicles.

"Look. I'll be back. I'll be back with the medicine and all of this will just. Be past." 
She put her hand up like she didn't want to hear the next thing I had to say. The gesture came as a relief because I found I had no follow-up.

I put some things in a bag and, sweat welling in sheets across my forehead, on my arms, and down my back, hobbled for what felt like several miles but was probably only about a thousand yards. I was familiar with the territory. I used to take long hikes up into the foothills to clear my head before conference calls. I would wake up early and wander through the bright crumbling wilderness while Taichea slept under the Mexican blanket in the dome tent. The terrain was like a superdimensional map of all that humankind had achieved. I'd follow a winding, improvised path, awestruck by the great diversity of objects that I found, always ending up at my desk on the beach, where I'd start up my device, connect to the network, put on my headset, and bark commands at my direct reports who sat in horrified silence around a slick phone in a conference room in the Financial District. Everything had a brilliance to it in those days, a compact clarity. I sat in my desk chair on the beach in flip-flops and boxer briefs, staring out at the horizon, my head emptied and alive, doling out the sort of withering directives that made me legend in the minds of my peers and followers.

Then the markets fell. And with alarming speed, everything else fell away in turn. I received a roaring tide of frantic calls followed by a wave of panicked all-caps emails and then a scattering of desperate texts and then there was nothing but the "service unavailable" message hovering on the gunmetal screen of my device.

I trudged through a shallow tidepool caked over with coppery surf that popped and sputtered as I moved through it. I saw a gutted aluminum trailer home erupting from a pinkish slurry, vomiting glow-in-the-dark windshield dice from its open front door. On a hill beyond there was a jagged pyramid of a hundred or so white Chinese hardhats piled up like the skulls of monks, topped by a Tekken 9 arcade cabinet, the composite frame of which was swollen and separated, rimed with a sick yellow crust. I passed a vinyl lawn ornament in the shape of a snowglobe that was partially inflated from the heat. The team of reindeer trapped inside was furry with black fungus. Hundreds of Nerf darts littered my path like grapeshot cast on the battlefields at Gettysburg, and in the distance a fiberglass restaurant chain mascot lay with its braincase smashed. I marveled at how the things had gotten to Dokken, and how it had come to be an inhabitable surface at all. When my father ran United Polymer the garbage patch was little more than a speculation. It couldn't be seen by satellite or by the naked eye, and the threat it posed was so remote that nobody paid much 
attention. Suddenly, though, there was a small, rainbow-colored island spinning at the center of the gyre. I remember the photograph that my father tried to hide from me of a group of scientists balanced on its surface in T-shirts and running shorts, staring ruefully into the distance. He was ashamed of the picture but I found it fascinating. The objects collected in the gyre told a story that no single human hand could author.

Beyond the mascot, which was a muscular cheeseburger dressed as a ninja, there was an oblong depression lined with a patchwork underlayment of parched tarps and wrappers, lengths of tattered plastic woven together and shot through with tangled bits of safety-orange fencing and drag nets. The dyes and colorants used to brand the various materials had faded and bled to create a variegated tapestry. Little fronds of torn poly whipped in the breeze. There was a slick pool at the bottom of the depression and I could see even from far away the dorsal fin of something that still lived. The fin wagged slowly in the baking heat. I hadn't seen anything alive on the landmass except for the red mites that were everywhere, even grasping their way along the insides of my eyelids. I sidestepped down the slope until I came to the water's edge where I could clearly see that the animal was a dolphin. Covered with tiny sores and bites, it looked barely alive. I squatted for a better view and when I did so the dolphin reared back to regard me with a single cobalt eye. It had a graphite apparatus clamped to its forehead and it appeared, even though it was an animal with no real expressive features, to be in a great deal of pain. I sloshed into the grimy pool, which was butter-thick with musky yellow algae. The dolphin heaved and flapped in an effort to flee but the water was too shallow. It couldn't produce any momentum, so it just slapped gracelessly in the muck.

"Easy," I said.

"We have many fine options as far as beverages are concerned. You please take a moment to look at the menu," the animal responded through the apparatus, which translated its yips and clicks with startling clarity into English II.

"Pardon?"

"You would like to try our kimchee sampler?" The animal lifted its flipper in a defensive pose, staring at me with the one eye.

"Do you-you need to get back to the sea, don't you?"

"You please take a moment-"

"This is no place for you."

"-to look at the menu. Many fine dishes."

I was not going to be able to carry the dolphin myself. "Hang on, buddy," I said. I tried to place my hand reassuringly on the dolphin's flank but it flinched. 
I thought about saying to hell with it but the animal looked so despondent. I wouldn't be able to live with myself if I walked away. I circled the depression looking for something I could use as a sled to carry the dolphin to the shore. It didn't take me long to find a cracked plexi billboard display screen for a personal body lubricant called SlutCracker. I quickly braided a chain of plastic grocery bags into a tether, which I then tied to one end of the screen. I hauled the thing down the slope to the sludge pond.

"I'm going to lift you onto this," I said. I felt oddly comfortable talking to the dolphin, who seemed to really get me. "Will you let me lift you up? I promise to be gentle."

"Would you like me to top off that cola for you?"

I approached the animal and it did not buck or squirm. It allowed me to straddle it and drag it through the ripe grime and up onto the makeshift gurney. I remembered a scene from a film I'd watched as a child where rescue workers ladled water over a beached whale's back as they hauled it out to sea and I did the same with the dolphin. I cupped my hands and poured the brackish gunk down the length of the animal's body and it didn't seem to mind.

I pulled the sled along the path I'd taken until I reached the dome tent.

"What is this?" Taichea said, rising from the overturned bucket she used for sulking when she wasn't eating pork from a can.

"I found him in a sort of a gulch. He talks!"

"Oh," she said, putting her hand to her face. "It's one of those talking dolphins."

"You've heard of a talking dolphin?"

"There was a restaurant in Korea that was famous for it. They attached these devices to the dolphins' heads and trained them as waitstaff. Some luxury resort on Jeju Island."

"You think this dolphin came from Korea?"

"What do you think of our beautiful country?" the dolphin said, which more or less cinched it.

Taichea made a sour face. "So you've brought a dolphin back, but where is the medication?"

"Well. I was only out there a short while. You can't expect me to have found it already."

"But you brought back a dolphin."

"It talks!"

"Can it cure AIDS?"

"I haven't asked." 
"That's great. Make a joke about it. Your unborn child is laughing inside me."

"Well."

"I hope you're proud."

"A country with a proud, long history, mountains hidden by clouds," the dolphin said. It reared its head and made a clicking trill in the direction of the water that the device could not translate.

"I'm just taking him to the sea," I said to Taichea. "I will be right back and I will find the medicine and we will be fine."

She sat back on the bucket and bit down on her fingertips. I did not know how to make her happy. Didn't have a clue.

I dragged the sled down to the shoreline where the water lapped against a crispy upcropping of melted Halloween masks, all of the same stoic silver robot man. The masks shattered as I dragged the screen into the water and I slipped right in over my head and down into the velvet depths. I felt the braided plastic rope tug at my neck as the screen descended toward the ocean floor. It carried me down into a dark suspended reef of plastic fronds and fragments that chafed my entire body. With all my remaining strength I untangled myself and floated slowly to the surface, my limbs like ragdoll parts. I surfaced some yards away from shore, my head draped in perforated bread bags, just in time to catch sight of the dolphin as it surged out into the clotted waves, dodging a barnacle-encrusted home entertainment center and the sunbleached carcass of a robotic vacuum.

That night I lay in the dome tent at a safe distance from Taichea, shuddering in the throes of a deep fever, my eyes fixed on the nylon vent at the apex of the dome. I did not think that I would live through the night and for the first time-truly the first, though it must seem like I am making this up, since I had already come to terms with the fact that I'd contracted a virus that I was almost certainly powerless to defeat-I wondered what my death might really matter in the wild and unfathomable course of the universe. I was aware that countless men and women throughout the ages had chewed on this very notion as they looked up into the luminous heavenscape but I had never thought to do so myself. I'd never had any reason to doubt my ascendancy to greatness as the $\mathrm{COO}$ of the second most successful plastics manufacturer in the world, and because I could not come up with a reason to live that held my attention for more than a moment or two, even when I considered the possibility that the child I'd sired might go forth into the future and rekindle the world with the 
flame of human ambition, I gave myself over to the virus and waited, shaking, for it to take me.

And then it was morning again and I woke to the smell of oven-toasted bread. A low yeasty smoke that made me long for the Financial District flat I'd lived in with my modest staff back when there still was a Financial District. There I could sit by the window with my headset on and watch the sun strike the towers by the esplanade while Wen Wen prepared toast and pepper tea in the kitchen area. But the smell that woke me could not have been toast because we had no bread on Dokken save for the moist canned variety that we used only on holidays. Because it could not be toast I felt immediately that something was wrong. I turned toward Taichea, but she was gone.

I rushed outside in my briefs. Taichea was kneeling at a sterno can, cooking something skewered to a metal stake over the blue flame.

"What are you doing?"

She turned to me, and there was a softness in her face that I had not seen since before she'd discovered the sarcomas. "I was-I'm sorry for what happened yesterday."

"Oh," I said. "I-take full responsibility for that. I-"

"Please," she said, offering the overturned bucket. "Let's start over, you know, like they say? I am making you a delicious breakfast and then you'll go and you'll find the medicine."

"We can do this," I said, nodding cautiously.

"We can do this."

I looked at the food she was preparing. "That smells amazing. What is it?"

"Just the canned meat blend. What we've been eating all along. What are you smelling?"

I looked out toward the shore. The sky was dark and heavy with purple clouds but I could see something shearing the mirrored surface of the water. "Hey," I shouted. "That's the dolphin. The dolphin is back!" I took off toward the beachfront and got down on my knees as if the dolphin might leap up out of the sea and into my arms, licking my face like a puppy would. As the animal got closer I saw that it was pushing something toward me with its snout, a white waterlogged box ensnared in brown raggings of seaweed. The dolphin came right up to the rim of the landmass and pushed the box up over a tightly packed berm of deformed sporting equipment and even before the bloated walls of the box split along the seam, spilling the prescription bottles over the surface of the beach, I knew what the dolphin had brought me. I snatched up one of the amber containers to confirm my hunch. Xytomitol, the AIDS killer. 
There were maybe seventy-two bottles of the stuff lolling on the beach at my feet. I worked the child safety cap off the bottle in my hand and poured the whole thing into my mouth. I wanted not so much to get rid of the AIDS but to torture and decimate it. I wanted to perform the pharmacological equivalent of tying the virus to a chair in a basement room and clocking its face with a set of brass knuckles until nothing remained but blood pulp. I gagged on the load of pills, spilling a few as I huffed and wheezed. The dolphin watched with its eyes like black diamonds, revealing nothing of its impression of me.

I turned back to the camp with chipmunk cheeks, my arms upraised in a champion's pose. "I'm cured!" I shouted.

Taichea was standing by the bucket, staring dumbstruck at the horizon behind me, the color in her face draining to a translucent slate tone. The skewer lay on the sterno can where she'd dropped it, the meat sizzling and sputtering in the small fire. I turned back to the sea. The sun was half-covered by a roiling mass of clouds that seemed to billow in reverse. Along the horizon as far as I could see in either direction there was a razor-thin streak of white fire lighting the clouds from below.

"Is that China?" I said, and Taichea may or may not have said something. I could not hear her voice over the song the dolphin sang as it took off into the open water.

"Arirang, Arirang, Arariyo.

"Arirang gogareo nomoganda.

"Cheongcheon haneure jan byeoldo manko ureene gaseume hemangdo manta." The tinny synthetic voice chiming a terminal lullaby into the muted world. 


\section{The Snipe}

The women sat behind the café at one of a handful of artfully selected, mismatched tables scattered around an elaborately aged fountain. It was the custom of the women to gather there on Tuesday and Thursday mornings. They had begun the ritual out of practicality, using the venue as a gathering point for the local chapter of the Future Species Initiative, which was an organization that staked out wetlands for waterfowl that did not yet exist. The early meetings were forced and unpleasant, framed by a baleful sense of duty toward the unknowable future. Privately the women wished that one of them, some other one of them, would send around a note excusing themselves, which would set them all free until the next scheduled meeting. But in spite of their individual disinclination to foster a relationship, a sort of hazy camaraderie crowded in around them, and they found, as time passed, that the meetings filled a dreadful, yawing void in their lives.

"Did I tell you about my cat?" Wendy said. "What it's doing?"

Therese and Dionne shook their heads.

"It's been pissing by the radiator. The parquet floor. The original floor. I'm telling you. The cat piss warps the boards. They're coming up, popping out. Not to mention the smell." Wendy was particular. She'd spent several years researching apartments in the city before settling on a loft that was once a workshop for a garment manufacturer. One could still see the rust-colored footprints of the sewing machines in the floorboards. She had almost no furniture in the place-just a bed and a spindly, wheeled table for her computer. Furniture, she'd explained, wasn't worth the investment required to get what she wanted. Therese, on the other hand, couldn't keep things at a safe distance. She was possessed by the urge to even out the number of things that she owned with the number she didn't own.

"We told you that would happen," Therese said, half-smiling as she brushed a constellate of crumbs from the table, lingering evidence of the pastry she'd eaten too hastily. "The cat, the things it would do."

"It's not the piss. Listen. Listen to me. I clean the floor with the special 
cleaner. The one that gets rid of the smell. I get it under control, to an acceptable state of whatever. I put the cleaning bottle down and I put a big cardboard box in front of the heater. Block the cat from going back there."

"The box catches on fire."

"The cat, the next time I come home, has pissed on the bottle of cat piss cleaner. Right on the bottle."

"The cat wants to start something with you."

"I'll kick the cat. I will." Wendy nodded as she said this, looking solemnly down the length of her slim paper coffee cup.

"No! It's not the cat's fault."

"Then whose? Tonight I'm going to kick the cat. I'm declaring martial law."

Dionne stood abruptly to answer a call. She drifted toward the back entrance of the café, her free hand pressed against the small of her back as she spoke into the phone. Wendy and Therese watched her sway slowly back and forth as she walked away from them.

"It's Russell," Wendy said sharply.

"Is that-"

"Yes. Otherwise, why all the drama?" Wendy made a whistling sound with her teeth. "It's not going to end well. It never does."

Therese nodded silently. She watched Dionne speaking to her lover, head bowed, her free hand touching her brow, involuntarily tracing its shape. She smiled and scanned the customers, blushing at something Russell had whispered to her through the phone. Therese felt a sharp tremor, a brief, radiant spear of longing. She coughed and rearranged her scarf, flattening it against her shoulder.

"I should go," Therese said. It came out soft, like elevator music.

"Well said. Looks like this won't end anytime soon," Wendy answered, waving dismissively in Dionne's direction.

Therese stood and took her handbag in both hands.

"I just feel badly for Art," Wendy said. "Can you imagine?"

"No."

"If he finds out."

"I know."

"People who do that sort of thing," Wendy said, and then paused as she put her cup down. "I'm sorry. I think they should be punished. It's just awful."

Therese nodded. Wendy was not forthcoming about her past, but Therese knew something lingered there, a terrible thing that she protected like a cornered animal with a damaged limb. 
"To do something like that. Secret lives. The worst kind of." "I know."

The throat of the mailslot was stuffed with a halved sheaf of circulars and promotional offers. Therese reached down and tugged at the papers. The topmost offer tore in a ragged, sawtoothed pattern as she pulled, shearing the face of a smiling man who was reading the label on a tube of ointment. She tugged harder and everything spilled out onto the tile floor. She bent to collect it, sorting the junk mail from the real mail. There, half hidden in the pile, was another letter from the stranger. She'd come to know the quality of the stranger's printer ink, how it streaked and aliased. There was, also, the absence of a return address and the bland flag stamp affixed with precision in the upperright corner.

Therese squatted in the foyer for a long time, holding the stranger's letter delicately with her fingertips, as though it might flake away into ash. A severe ray of sunlight from the high window heated the small space. The back of Therese's neck went red.

This letter was longer than the others, broken into shorter chunks that scrolled down the page like a legal document.

"Dear Ms. Davidson," it began. "In the interest of full disclosure, your husband has been spotted in the following locations at the specified times over the past month. The purpose of this letter is purely informational. No action is suggested or implied.

"On February 7th," the stranger continued, "your husband met Ms. Dawn Shaunessey for lunch at The Capital Grill. The duration of this visit was approximately 1.5 hours. After lunch, the two descended into the parking garage and entered your husband's vehicle for an additional 17 minutes. Ms. Shaunessey exited from the passenger side door of your husband's vehicle at 1:22 p.m., after which both parties returned to their places of work."

Therese stopped reading the letter. She tried to remember February 7th but couldn't distinguish it in her mind from any other day. She would start remembering, she resolved. She would start writing down the days, filling a notebook with every detail she could bear. She would find the pattern, learn to recognize the signs as they came instead of in hindsight. Instead of receiving them from the stranger.

"Your husband was seen on February 16th at an inn with Ms. Shaunessey. The two talked at length at a corner booth. On three separate occasions during the conversation Ms. Shaunessey collided playfully with your husband, resting 
her head briefly against his shoulder. Your husband clearly craned his neck to inhale the scent of her hair-her shampoo or perfume, or something else. It is not the purpose of this letter to raise conjecture about the behavior observed. The two left the inn at 10:33 p.m. after roughly 2.5 hours and walked down the street to your husband's office building. They entered the building and remained inside for an additional hour. The light in your husband's office did not come on at any time during this period. The two exited the building at 11:31 and your husband drove Ms. Shaunessey to the Ashway commuter rail station before returning to your house at 12:14 a.m."

The letters always ended the same way. "Your husband's activity will continue to be monitored and logged. You will continue to receive updates. The purpose of this letter, again, is purely informational. No action on your part is suggested or implied. Many individuals, faced with a set of scenarios such as these, have been motivated to take action. But that is not the purpose of this document."

Therese, on her knees, collected the rest of the mail from the foyer floor and held it to her chest. The house was still and silent as a pine forest.

"What's this?" Nelson had rushed quickly to the table where Therese had left the open letter from the stranger. He held it out toward her with one hand while spreading out the rest of the mail in a fan pattern on the tabletop. His tie was half undone, hanging loosely around his neck.

"Another one," Therese said after pausing to clutch her collar.

Nelson sighed. "This is getting ridiculous. I'm going to call Anders and see where we're at with the investigation.” Anders was a cop and a high school friend of Nelson's. Nelson had brought the first batch of letters to Anders so that he could open a file on the stranger. He was being groomed for the state senate, and he had been told to expect personal attacks. People coming out of the woodwork to call his integrity into question.

"Wait," Therese said.

Nelson looked up from the table. "What?"

"I just," she said, and then she couldn't finish so she looked away at the recessed bookshelf through the doorway into the next room. It was getting dark.

"You don't actually believe any of this."

"No," she said. There were either too many unread books on the shelf, or not nearly enough time, but she couldn't tell which.

"Look at me," Nelson said. "You don't believe this. You don't, okay? Not 
any of it. We've been through this. It's someone-someone trying to do something to me, to smear me or something. A person in my position, with my kind of visibility, people just want to find a way in, to tear me down. I just don't know, but don't ever think that it's something else."

"I don't."

Nelson came forward and gripped her shoulder.

"Because if you were," she said, and then stopped. Her hands felt grainy and full. "If you were, you would just put it out there and-we'd be done with it." It was not all she'd wanted to say, but it started to edge its way into the desired territory.

"Don't be ridiculous," he said. He pressed her toward him. "Whatever this person writing these letters is trying to do," he said, "we can't let him tear us down. Not like this. Not this easily."

She moved toward him and accepted his embrace. He ran his thumb up and down her spine. She rested her face against his chest and looked at the radio on the kitchen counter. She wished it was turned on.

Therese opened the trunk of the Escalade and hung her bags from the small plastic hooks on the seatback that were designed specifically to hold shopping bags. The trunk door shaded her from the harsh pink spotlights that illuminated the plaza's mostly empty lot, and the cool air from inside the truck provided a momentary diversion from the low, moist heat. The bags were filled with clothes she had bought without trying. She didn't like dressing rooms, so she just bought as many of the cheapest garments as possible and returned the ones that didn't fit. It was another way to stuff the gargantuan days with errands and microtasks. She closed the trunk and moved around to the driver's side door, and as she got in she saw that there was a vehicle idling in the row directly behind her with its lights on.

She sat in the lot for a while to see if the other vehicle might drive away. It did not. She put the truck in drive and began to slowly pull out. Her tires popped and crushed stray fragments of blacktop as she rolled toward the exit ramp to the highway. She looked in the rear view mirror, where the lights of the car behind her remained clearly in view. She waited for the lights to diminish, but they grew larger instead as the other vehicle advanced in tandem. She accelerated, faster than she would have normally but not so fast as to appear frightened or suspicious, because even as her blood cooled and her mouth went dry with fear, she did not want it exposed to anyone who might be watching her. 
She took the ramp and veered right without stopping at the light. The other vehicle kept up, almost as if she were leading it along on a string. She straddled the lane marker all the way to the merge point, making it impossible for the other vehicle to pass her. She wasn't sure why this was important, but it felt that way. The other vehicle moved to the right lane and came up close behind Therese.

She moved to the left and let the other car overtake her. She could see in the passenger side mirror that it was a deep blue sedan with darkened windows and a spoiler. It pulled rapidly up alongside the truck and hovered there, keeping pace with her, as the lane emptied out onto the highway. She looked over and saw a young man's face peering back at her from the driver's side window. The man stared at Therese, not even glancing at the road. He had tiny fox eyes and his head was shaped like an inverted almond. He wore a pristine white tank top, and when he saw Therese looking at him he slowly lifted a handgun into view. It was short and fat and it looked almost like a piece of jewelry in the young man's hand, or a silver chalice. This is what Therese assumed of it when she first saw it, which may have been why she detected a fleeting disappointment cross the man's face. She hadn't provided the appropriate level of alarm. The man held the gun to his chest and sped off ahead of Therese. She kept driving, pacing herself in the rightmost lane, driving as though nothing had happened, her blood cold and surging.

"Your husband," the next letter began, "met Ms. Shaunessey outside Toscano’s, an Italian-style restaurant on Western Avenue. He held out his hand for her as she exited a taxicab and she accepted it. They entered the restaurant holding hands. Inside, your husband was visibly holding hands with Ms. Shaunessey over the table for the majority of the meal, which lasted roughly two hours (a copy of the receipt is attached-the original will remain on file). The pair consumed the lion's share of a bottle of red wine. When the meal ended, your husband and Ms. Shaunessey left the restaurant arm in arm and embraced while waiting for a taxi. The couple exchanged an uncountable number of prolonged kisses. The taxi arrived at 11:42 p.m. This event occurred on March 11th, also (coincidentally) your date of birth."

"Anyone can fake a receipt," Nelson said. He had his back up against the refrigerator, his shoulders making a disorganized mess of the tiny, magnetized photographs Therese had set there. He was looking hard into his drink, something cold and stinging inside a promotional freebie pint glass.

"Please stop doing this to me." 
"I'll have Anders look at the receipt. He'll be able to tell in a second."

"It was my birthday. You said. You had an event."

"Because I did have an event, Therese. The Governor's Mansion. I could get three people on the phone to confirm this."

"I'm begging you. Just stop." She started shaking. She gripped the countertop to steady herself.

Nelson kept staring at his drink. He tipped it forward slightly, loosing the ice cubes, which rang out against the largely empty glass. His face unfolded with childlike wonder as he examined the ice, tipping the glass one way and then the other.

The sun fell and the kitchen was lit only by the gritty blue light of the moon. Therese slowly lowered herself to the floor beneath the pass-through so that she could no longer see Nelson's face. She gathered herself in a bunch and lay down.

Nelson continued to agitate the ice cubes in his glass. Then he stopped and took a sip. Even without looking, Therese could tell that the sip was staged. The cubes rattled at the base of the empty glass. Nelson crunched an ice cube until it liquefied. With his mouth full of water, he said, "Okay," and put the glass carefully in the sink. Therese listened with her ear to the floor as he padded in his sock feet down the hallway to their bedroom.

Therese remained on the floor in the dining room for as long as she could stand it. Her heart churned frigid blood through her limbs, numbing the extremities. Against her will she hovered in a sleepless holding pattern. When it became clear that Nelson would not return, would not kneel and run his hand through her hair to comfort her, she relaxed her grip on her knees and spread out on the floor. She lay for another stretch of time, slowly rubbing her cold palms together, unable to warm them. When she finally righted herself, the dining room was flooded with darkness. She read the LED display on the entertainment center. Hardly any time had passed at all.

"This is the thing you do," said Wendy. They were once again at the table in the courtyard behind the café. "If this is really the thing you want, the thing you do is to construct an accident."

"You mean-" Dionne put her fist to her mouth and coughed.

"You figure out some way to lead him into a situation where she sees the two of you together. After that, it all unravels on its own."

"That seems. Mercenary."

"But that's-you see?" Wendy pulled her hair back with one hand, stabbing 
the air in front of Dionne's face with the other. Her eyes were round and full of a kind of ecstatic pursuit. "That's just what it is. That's what you do. If you want it. Put an end to the deceit. The sneaking. It's better for everyone."

A small boy climbed the low wall that ringed the courtyard and disappeared behind the foliage. The boy's mother shot up in her seat and scanned the area with darting eyes. When she saw the boy's red sneaker in the peat, she frowned and seated herself again.

"I guess," Dionne said, and then stopped. She folded her paper straw wrapper into a sort of squat duck and placed it delicately atop the sugar shaker. "I'm worried. Everything is working now, the way it is. These two things. I think I might like it better than if I just went with Russell."

"Doesn't make sense," Wendy said, retracting her head as she frowned.

"I feel better about myself when I'm with him. He feels better about himself when he's with me. And the wife, she gets a happier man." Dionne couldn't conceal a half-smile as she said this, perhaps for the first time to anyone but herself.

"And Art?"

Dionne shook her head and glanced up at the treeline.

"That's just what I don't like about this," Wendy said. "It's rotten to the core and it's not going to last. You can't see that?"

"What lasts?" Dionne answered, looking away. The boy's mother was trying to coax him from behind the plants.

"You're a silent one today," Wendy said, shifting to address Therese, who sat with her legs crossed, thumbing her palm.

Therese nodded and shifted her mug from one hand to the other. "I guess I'm just-it's just one of those, you know, days."

"How is your perfect system?" Wendy said, winking almost imperceptibly. "We never hear about the politician anymore."

"Oh," Therese said. "Yes. He's busy."

"The campaign," Dionne said, nodding.

"Yes, and. It's just a busy time."

"That will pass."

Therese nodded.

"You see?" Wendy said to Dionne. "That's what you want. Right there. The security."

Dionne looked at Therese as if she'd made the statement instead of Wendy.

"It's not," Therese said, holding out her hand as if she could halt Wendy's language from filling the air. 
"You'll never have that with your. This arrangement. You've got to make a choice. And if you can't make a choice, you've got to make it so things unravel on their own."

"No, I don't," Dionne said. She got up from her chair and began collecting her things in the green vinyl bag Russell had recently bought for her.

"Well," Wendy said, throwing up her hands, gaping at Therese in mock exasperation. Therese hunched over and stared at her hand. She pressed her thumb into her palm and held it there until the flesh whitened. Both of them watched Dionne maneuver quickly around the courtyard tables, holding the bag closely under her arm.

"Did I-" Wendy said, and then gasped. "Am I not right in this?" She addressed Therese as she spoke, but it was as if she was talking to someone standing right behind Therese, a person who responded the way Wendy wanted her to respond.

"I mean-" Wendy said. "No, I'm doing what any friend would do. I would expect the same from her. If I were in-" She broke off and picked up a loose sugar packet from the table, which she tapped gently and repetitively against her index finger.

The parking lot was full when Therese arrived. She read quickly through the newspaper, holding it taut in her hands to still them. The articles and advertisements drew her toward them in percussive waves, but the thing she was steeped in wouldn't allow her to touch bottom and lose herself in the articles. She was in the mall parking lot, waiting for the man with the gun.

She scanned each page of the paper twice, retaining almost nothing of the content. When she was finished with the paper she scanned the circulars. There were some that she couldn't even look at, they so repulsed her. Cheap multi-colored brainsplatter kits for parties and a vinyl saddle for riding on the homeless. She folded the paper in a neat pile and put it in the passenger seat. She opened the glove box and found a half-eaten package of spice drops. She ate the drops by the handful until they were gone. Families passed by her car carrying bags and boxes. The children stared at her as they passed, their faces still and somber.

The sky darkened and the lights that craned over the parking lot sputtered on, row by row. Cars pulled away in loose clusters, queuing up by the exit ramp. The mall closed, and Therese watched young attendants shutter the storefronts with rolling steel curtains. The remaining vehicles lurched in unison toward the highway, merging in slow motion, their headlamps bathing the 
lot in fading orange light. Therese watched the cars struggle up the onramp to the highway, where they sped off into the clouded darkness. When she turned again to face the mall there was just a single car left sitting in the lot, a blue sedan, its headlights trained on her. A column of exhaust curled away from the rear of the vehicle and snaked across the empty lot, dissipating in the diminishing gray light.

Therese waited to see what would happen. The other car did not move. She could not see a figure behind the wheel. She looked at the LED clock set into her dashboard, which read 9:35. She put on her black leather gloves and stepped out of her truck. She walked slowly toward the blue sedan. She was still waiting to see what might possibly happen.

She came around the driver's side in a wide arc. She saw the man's almond face clearly in the wispy light of the overhead lamp. Night shadows brought his features into sharp relief. He looked like a woodcut; his cheeks, chin, and the lines that framed his mouth carved away from the darkness inside the car. His left cheek bore the pockmarked print of severe adolescent acne. She walked up to the driver's side door and stood with her hands at her sides. The young man did not move. She saw, in his eyes, a tightness that might have been a well-concealed panic.

"I know what you have in there," she said.

The man's eyes widened just slightly. His ears drew back against his head.

"And I want to know where you got it."

The man looked away from Therese, out over the hood of his car. He seemed to be thinking it over. Therese stood as still as she could possibly make herself. She could see, even in the scattered, diffuse light, that his left eye pulsed when he clamped his jaw shut. Without looking at his hands, he put the car in drive and pulled quickly out of his spot. Therese turned and watched him swerve out toward the exit ramp. He paused for a moment at the rim where the ramp let out onto the highway, and she could see the dim profile of his canted head as he peered at her one last time before sluicing into the stream of traffic.

Therese pivoted slowly on the balls of her feet, deliberately grinding the soles of her pumps into the craterous blacktop. She was alone in the lot, not a single mall attendant or security vehicle snaking along the service road. She walked to her truck and got in. She looked at the empty cellophane bag that had held the spice drops. A pinch of sugar crystals remained in the bottom of the bag, and she lifted it to her lips and poured it into her mouth as if she were drinking from a wine cask. The sugar pooled in the center of her tongue 
and she held it there until it dissolved completely. She put the car in drive and crawled up the ramp to the highway.

It was nearly 3:30 a.m. when she slipped quietly into the apartment. She stood in the entryway, the rifle in its padded nylon case slung across her back. The furniture in the living area was just barely recognizable against the flagging gray night. She carefully removed her pumps and placed them on the boot tray, one by one, side by side, as though someone still stood in them, a ghost standing against the wall. She slid across the rug in her stockings until she reached the coffee table. She took a brief survey of the room, her head darting from object to object. She knelt by the couch and slid the rifle case underneath.

"Hey." It was Nelson, standing in the bedroom doorway in his undershirt and boxer shorts. He held a rolled sheaf of photocopies in his hand, a red Sharpie notched between his index and middle fingers.

Therese froze in an awkward half-crouch.

"The hell." He sounded confused and agitated.

"I lost something."

A long silence followed.

"Turn the lights on if you lost something."

She realized that she was lying and that she wouldn't be able to keep lying. But also she might not want to get away with the lie. So she remained on the floor.

"You heard me. I said 'turn the light on."

"I found it," she said. "I found it. I'm good."

She rose slowly, cupping her palms as though she held a fluttering moth.

Nelson hung his head and roughed the back of his neck with his free hand. In the fizzed light she could barely make out his wiry, recessed features. He disappeared into the bedroom, and she heard him slump against the mattress and shuffle the papers. She carefully opened her hands, having convinced herself that she held something there.

Therese spent the next several days observing rooftops and vantage points. There was an old jewelry store across the street that would have an exceptionally clear view, but no easy access to the roof that she could see. Better was the warehouse immediately behind the jewelry store, which rose several floors higher and sported a massive billboard advertisement for high-speed internet service that would serve as ideal cover. She could aim through the squat aperture between the roof ledge and the billboard frame and go more or less unde- 
tected. Furthermore, she discovered after some research that the warehouse roof could be accessed by a recessed fire escape that was not visible from the street.

On the fourth day she waited in her truck for darkness to fall. She parked on a side street behind the warehouse, feeding the meter periodically with the change she received from the donut store, where she'd bought a bag of donut holes. She sat in the truck and ate them, one every ten minutes until they were gone. The holes fit perfectly in her mouth, and she held them there until the glaze disintegrated, leaving the sponged sphere of dough.

Sometime after eight she took the soft case from the back seat and got out of the truck. A young couple walked by her, the woman leaning into the man's chest, laughing at something he'd said. The man scanned Therese with an expressionless face. He did not linger on the case strapped to her back. No one else on the street was close enough to see her. She moved quickly down the alley to the fire escape. She could just barely reach the lowest rung, but she managed to pull herself up to the first landing. She crouched next to the oxidized stairwell and peered into the warehouse window. It looked empty inside. Her lungs trembled already. She gulped at the sharp night air, ascending the stairwell as quickly as possible until she was on the roof.

She crawled over to the billboard. Workers had left aluminum buckets of paste by the vertical supports, and she crept toward them for additional cover. She rested her shoulder against the roof ledge and peered through the slit at the building across the street. The lights were on but Therese couldn't see anyone inside. She slid the rifle case from her shoulder to the tarred surface of the roof, which retained the heat of the afternoon. She unzipped the case and unfolded it. She had not seen the rifle since the clerk had fitted it into the case as she ran her card through the reader. He'd asked her what she was after, coming into the all-night armory at such a late hour. She'd rehearsed that, if asked, she would tell a story about a wild dog, but in the moment she couldn't muster a meaningful phrase. She just opened her mouth and then closed it again. The clerk had simply nodded, though, freeing her from having to generate a response. "You like pink?" he'd asked. It was her turn to nod.

She had purchased the pink rifle as well as the pink magazine loaded with pink bullets that looked like glossy lipsticks. "The ladies tend to go for these," the clerk had said. "I had no reason to suspect you'd be any different," he said. She might, in another context, have bristled at the way he'd addressed her, his voice chalk-dry, like something rattling in the bottom of a rusted can. But at that moment she wanted nothing more than to fall into step with the legions 
of ladies who had come to the armory in search of pink rifles. She imagined herself at a shooting range with the ladies, all of them standing in a perfect row, taking aim at paper targets in unison. She thought that when she was done with what she had to do, she might find these ladies, wherever they were, and broker a friendship with them. This notion elevated her task to something approaching justice.

She swung the barrel of the rifle around and slotted it through the aperture, cradling the stock with a gloved hand as she squinted into the reticule. The rifle shook in her hands. She had to mash the reticule into her eye socket to steady it. She swept deliberately across the row of windows along the top floor of the apartment building, examining the objects and peripherals they showcased. Spare, low furniture adorned with acutely degraded artifacts and curios, slim stereo speakers set against the far walls, the blurred pulse of the nighttime television programming, sets of legs and forearms at rest, set into angular couches.

Therese settled on the window that let in to Wendy's apartment and waited. Even through the reticule she could see the rust-colored footprints of the sewing machines that indelibly marked the floorboards.

In time Wendy appeared in a blue leotard, carrying a rolled-up yoga mat under her arm. She moved to the center of the floor, more or less centered in the window, as if she were praying for Therese to shoot her. She unfurled the mat and tossed it on the floor, where it collapsed in a rippled heap. Wendy appeared to sigh before bending to straighten it. She crouched near the floor, absently smoothing out the edges of the mat. Her midriff bulged over her thigh, expanding and contracting with her labored breath like a bellows. She swayed slowly from side to side, pulling her hands through her hair so that it went tight against her head. Therese could see rogue strands of silver around Wendy's forehead, shimmering like a delicate tiara.

Therese tugged at the trigger impulsively and the rifle went off. The percussive blast rattled her skull. She dropped the rifle against the roof ledge and pressed her palms into her eye sockets, where reflexive tears had pooled. Both her ears rang like heavy church bells played back at half speed. She lost her sense of direction.

When the vertigo passed she opened her eyes and blinked. It felt like she had blacked out, like she had been asleep for hours, but when she peeked through the aperture she saw that Wendy was standing at the window, craning her head around to try to catch a glimpse of the building's exterior. Therese saw that the shot she'd fired had taken out a chunk of brickwork on the wall just 
above and to the right of Wendy's window. In a single fluid motion Therese took up the rifle, aimed, and fired a second shot. She barely heard the blast; it came to her as if from the bottom of the ocean. A moment later, a white ring formed on Wendy's window, and a corresponding dark circle appeared on Wendy's left cheek. Wendy's head jerked from the force of impact, but she remained on her feet, slowly raising her hand to the cheek as though she'd just been slapped by a jealous lover. Her look was quizzical. She knelt by the window and put her head down, resting her temple against the casing. Therese watched for a long time to see what would happen next, but nothing did. Wendy stayed by the window, breathing heavily. Maybe she was praying. The vigil bored Therese, so she packed the rifle into its case and climbed down the fire escape.

"I'm telling you I have no idea what it is," Wendy said. The three women were gathered, as always, at the table in the rear of the courtyard. Wendy's face was obscured by a dark nylon veil and a pair of enormous, insectoid sunglasses. Her left cheek was puffed and mottled. A shiny emerald corolla of dried pus was visible through the veil.

"It's some kind of bite, though?" Dionne said. She was looking hard through Wendy's veil to get a better look at the wound.

"That's just about the only explanation I can think of."

Therese tried not to linger on Wendy's face, but found herself returning there repeatedly, compulsively.

"I heard something go 'pop' outside and I went to the window. Then there was another pop and I felt a stinging on my cheek. It was so much, you know, like a bee sting, where it started sort of dull and low and then just gradually got more and more painful."

"Did you see a doctor about it?" Dionne asked.

"I'm going to give it a few days and see if it clears up."

She glanced quickly one way and then the other before raising the veil to take a sip from her mug. A drift of foam caught the veil as she drank.

"I don't think," Dionne said, and then paused. "That doesn't look good. You should probably-"

"Maybe you're being punished," Therese said. She could feel a slight smile break out across her face. She tried hard to bury it.

Wendy and Dionne both turned and gave Therese a look. It was drastically unlike her to make such an accusation, even jokingly. The two women stared at Therese, who slowly backed into a defensive posture. 
Wendy cocked her head, as though she were addressing a disobedient puppy. "I'm sorry. Not that I even believe in that. Being punished. But for what? What are you even talking about?"

"I don't know," Therese said. She put her hands in her lap and clasped them. She opened her eyes as wide as she could to try to shake the urge to laugh.

"That's just," Dionne said. "That's just rude. I'm sorry."

"It's fine," Wendy said. "It's fine. I just don't get it, Therese. I don't get what you're suggesting."

"I'm sorry," Therese said, looking away from the other women. She concentrated on the arrowhead leaves of the Chinese money tree whose branches shaded their table and tried to think of things that made her sad.

"Are you laughing?"

Therese shook her head but would not look at the other women. Her chest quaked with suppressed laughter. Her whole body felt light.

"I'm glad you think it's funny," Wendy said flatly. She chewed her lower lip.

"I don't." Therese breathed in sharply. "I don't think it's funny. I get nervous. When I'm upset." She drew the back of her wrist across her face where a tear had fallen.

"Well."

"I'm sorry," Therese said. She was shaking.

"This is," Dionne said, shaking her head at Therese.

"Disgusting." Wendy shot up in her seat and started to walk away from the table. Her overcoat caught on the chair back, bringing it down with a crash. The other patrons turned to watch Wendy as she wove through the tables toward the door. Dionne sighed and collected her things. Therese's whole body convulsed with a kind of silent, wheezing laughter. She moved in slow motion, her lower lip peeled back in a half-grimace as she doubled over on the bench seat.

"Your husband's meetings with Ms. Shaunessey," the letter began, "were scarce during the month of April. It is assumed that you had a conversation with your husband about the content of these letters, and that he admitted to his encounters and agreed to alter his behavior. That is not the intended purpose of these letters, as they are strictly informational. But it does appear that, for a time, your husband attempted to end his encounters with Ms. Shaunessey. Unfortunately, on April 22nd at 11:50 a.m. your husband met Ms. Shaunessey at the intersection of Gaspee and Charles. Ms. Shaunessey entered his vehicle and the two drove out to the Waverly Point bridge. Your husband backed the vehi- 
cle under the bridge, and the two remained there for roughly 2.5 hours. Since that evening your husband has taken five more of these extended lunches to meet Ms. Shaunessey, always at the same intersection, always in your husband's vehicle, always under the bridge.

"Once again, the purpose of these letters is purely informational. No action on your part is intended or implied. Many individuals in your situation choose to seek assistance at this point. Many individuals choose to terminate the relationship. It is not our intention to speculate on the nature of your decisions; only to report on what we observe."

They were watching a cage match between two homeless men on television. "Your earlobes are like a woman's," Therese said, running a finger along the ridge of Nelson's ear.

"Thanks." Nelson snorted, half-grinning as he circled a phrase in the campaign document he was reviewing. He swatted at Therese's hand with his pen. She laughed and pounced on him, putting him in a tentative sleeper hold. He chuckled and jabbed his straightened fingers up under Therese's ribcage. She fell back on the couch, laughing.

"Seriously," she said, "was it your mother or father who had those ears?"

"I don't. What? I'm supposed to remember my parents' ears?"

"I would remember if I had ears like those."

"Great."

"No! I love them."

Nelson whistled through his teeth, which meant that he was done with the conversation. He turned the page and began circling more phrases.

"I want to know more about your parents," she said, laying her head in his lap. "I know hardly anything about them."

"They're dead."

"I'm not-I'm just. I want to know everything about you."

"That's scary."

"I'm serious."

"You know what you know."

"What do you mean by that?" she said. She lifted her head and craned her neck to look at his face, which was composed in an expression of mute indifference.

He squinted. "You know as much as you know. That's it. There are things you can't know, Therese. Things you can't possibly know. Can't understand. No use in trying to describe them to you. As if that could help." 
"I don't like that," she said, resting her head. "I don't like that idea and I don't like the way you said it. It does help to know." She turned back to face him. She was not comfortable in her new posture but she wanted to see him. "That's all we have, isn't it? Just the things, the things we say?"

Nelson blinked and cleared his throat. Therese watched his face move slightly in tandem with the show, as though it were rehearsing a set of realtime expressions. She saw the show reflected in the window behind them-a black man with one eye threw a white man against the cage wall. The audience hurled soft drink tumblers at the cage in response, the carbonated beverages splashing the black man's face. A camera closed in as he screamed something unintelligible at the crowd. Dark fluid streamed down the lines in his face.

Therese closed her eyes. She could feel sleep approaching. It came as a heaviness, a sense of being dragged down by a stone into something familiar and warm, an intoxicating ambient gel where she floated freely, falling but not falling, somersaulting through the void. 


\section{Full Metal Jhacket}

Dear Mr. Bonavita,

We at Warner Bros. Pictures wish to extend our heartfelt appreciation for your recent letter to us. The Motion Picture industry thrives on the dedication of film enthusiasts such as yourself. We cannot thank you enough for your continued support of the films of Stanley Kubrick. We're proud to represent his work on screen for millions of viewers worldwide, and letters from fans like you ensure that we will continue to bring high-quality entertainment to your community theater from directors like Mr. Kubrick, Steven Spielberg, and Michael Ritchie, director of the recent box office hit Wildcats, two complimentary adult passes for which are included in this letter as a gift to you.

We regret to inform you that Mr. Kubrick is unable to respond personally to your request that he change the title of his upcoming release. We're sorry to say that Full Metal Jacket has been reserved and is no longer available. We're confident that you will come up with an exciting and provocative alternate title for your film.

Best wishes and good luck with your production,

Gail Sheehan, Warner Bros. Pictures

Fingers whipped the letter onto the floor like it was a throwing star and picked up the metal folding chair that had the space heater on it and tossed it through the barn window. The glass shattered and a hunk of the window frame went crashing down onto the driveway with the chair, which made Fingers madder so he grabbed the space heater and hurled it out the window as well, which worked except that Fingers' desk lamp was plugged into the same extension cord as the space heater, and the shade knocked into the splicer and a pile of film reels, which hit the floor and went rolling, unraveling the raw footage he'd just picked up from the drug store. The desk lamp got caught in the busted frame on its way out the window and the space heater just slammed against the outside wall of the barn, cracking the slats.

"Hey," Apple said from the pile of old mattresses he and Fingers had found at the dump and dragged, one by one, back to the barn to use as studio furniture. 
"Don't 'hey' me," Fingers shouted. "That was my title, my fucking title. That fat fuck." He jumped up and did a sort of sideways kick at the smashed window frame, and the force of his own kick knocked him back into the tripod which luckily didn't have the camera on it. He rolled over onto his stomach and started punching the floor, hard, like he wanted to juice his own fist. The envelope from Gail Sheehan was near him on the floor so he crammed it in his mouth with his free hand and chewed it up, growling. The paper making a fluttering sound as it broke down to pulp.

"Take it easy," Apple said. He was backed up as far as he could go on the mattresses, gripping the canvas straps with white knuckles, as if the whole pile was about to fly away like a massive bird.

Fingers got up on all fours, breathing hard. He mashed the envelope in his mouth, groaning deep in his throat.

"What in hell is happening up there?" It was Fingers' dad, calling up from the backyard. He worked at the university as a professor of some kind, probably the kind with a degree in busting Fingers' ass because that's what he spent most of his time doing, it seemed like. He always knew when Fingers and Apple were trying to burn something or light off M-80s or shoot arrows into the convenience store parking lot, and he usually stopped them before they could carry out their plan.

"Get away from me and you smell," Fingers shouted down at his dad, spitting the gobbed envelope out the window. His face was past red, into a sort of whitish ghost look.

"I'll smell you in about a minute," his dad yelped, his voice straining with tightly capped aggression.

"That doesn't even make sense," Fingers screamed. He got up and started searching the room for something to huck at his dad. He went for the table where he and Apple had painstakingly recreated a vast rice paddy in 1/144th scale.

"Don't," said Apple.

"Who's up there?" Fingers' dad yelled. "Do you have Franklin up there?"

"Wouldn't you like to know," Fingers screamed. He gave a roundhouse kick to the window frame and the whole sill came loose. He grabbed the splintered wood and pried it from the studs.

"You were warned!" his dad shouted. "He is not to set foot on this property. Send him down right now." Apple was the Franklin that Fingers' dad was shouting about. He didn't like the name "Apple" any more than "Franklin," but he knew that Fingers meant it in a goodish way when he called him Apple, so 
he tolerated it. The reason Apple had to get out of the barn was that he was only twelve and Fingers was older, past high school in age, and Apple's parents didn't want him to be there.

"I will not do that," Fingers screamed, his voice breaking up with every syllable. He chucked the broken window sill at his dad. Apple got down from the mattresses and made for the door.

"Hey," Fingers said. Apple turned around and looked at Fingers' feet. He did not want to see Fingers' reddened, blotched face. "This isn't over," he said, almost whispering, his vocal cords blown.

Apple nodded.

"Mark my words. This hasn't even begun, is how far from over it is. We're getting that title. It's ours. I'll come over and get you when I figure out a plan, okay?"

Apple nodded again and slipped through the door, which was really just a sheet of plywood hanging from the ceiling by a tangled length of telephone wire. The barn was on Fingers' property, but it hadn't been used as a barn since the olden times when the town where they lived was a farm town and not a college town. Now the barn was the location of Fingers' film studio. It was the place where he and Apple were making an epic film about the Vietnam War that was called Full Metal Jacket until Fingers found out in Rolling Stone that filmmaker Stanley Kubrick was also making a film called Full Metal Jacket. It was a problem, but not the hardest problem Fingers had ever confronted, and he would come up with a solution soon enough.

Apple leapt down the stairs and ran out the side door of the barn so he wouldn't run into Fingers' dad, who was standing at the front, his arms crossed, watching the space heater slowly rotating where it hung out the window. Apple saw just a flash of the man as he booked toward the bushes separating Fingers' house from the Ellisons'.

"Do me a favor, Franklin, and don't come back here," Fingers' dad called out to him without looking away from the window. "I don't want another visit from your parents."

Apple did not look back. He cut through the Ellisons' backyard and the convenience store parking lot. The sun was still out, and the air was heavy with pollen and soil. His heart swelled in his chest as he sprinted home. It was Holy Thursday and he was going to be late for church.

He dashed up the porch steps just as Hugh was coming out. Hugh already had his shirt and tie and brown shoes on so Apple knew he was in trouble.

"The fuck were you, twat?" Hugh called out to him as he ran past. Hugh 
smacked Apple hard in the back of his head, which sent Apple face-first into the aluminum siding.

"Dipstick," Apple shouted, cupping his face with his hands. He shot up the stairs to the boys' room and grabbed a shirt and a tie. There was no time to change out of his sneakers. He would just have to take his chances.

Outside all the kids were already getting into the station wagon. The girls got the back seat and the boys got the wayback. Apple's father stood by the driver's side door, jingling the change in his pockets with irritation. His mother shook her head as she watched him run toward the car, and the look she gave him was enough to make something hard and cold rise up in Apple's throat.

Apple played the drums in the folk group, which helped kill the shapeless and interminable void of the mass. Holy Thursday was the second worst, longest mass of the year, just barely more manageable than the Easter vigil with its torturous Exultet. He sat behind the kit during the readings and dreamed about the rice paddy sequence. The camera would, with the aid of a sliding track they'd built from a thrown-away rowing machine, pass over the miniature landscape just like a helicopter, and the miniature figures he and Fingers created from matchsticks would look up as the helicopter swept past them, not knowing they were about to be torched into nothingness by napalm, an effect that they hadn't figured out how to pull off yet but which would, they were pretty sure, involve slow motion, a cigarette lighter, and an aerosol can of hair spray Apple had pilfered from the girls' room. He imagined how the footage might look on the screen at the Riviera, the theater in the center of town where he and Fingers went every weekend since he could remember, no matter whether the film they showed was something great like Romancing the Stone or utter crap like Out of Africa, which he couldn't imagine even a boring, sweater vest-wearing professor like Fingers' dad liking or even staying awake through.

The readings ended. The folk group lit in to a dark, sinewy rendition of "They Will Know We Are Christians," which was one of Apple's favorites. He swabbed the ride with his brush, hunched over the kit, brooding over the lumbering beat. The group drew the song down to a whisper and stopped. The priest stood, spreading his vestments as he invoked the homily.

"We tend, on this night," he said, pushing his spectacles up the bridge of his nose with a stout, calloused finger, "to focus on Judas, because Judas is so clearly the prime mover in the crucifixion. We see him very boldly go up to the chief priests and offer to let them know Jesus' whereabouts. But I'm more interested in the passage, later on, where the disciples, all of them, turn on 
Jesus. In Matthew 26:55 it says, 'In that same hour said Jesus to the multitudes, Are ye come out as against a thief with swords and staves for to take me? I sat daily with you teaching in the temple, and ye laid no hold on me. But all this was done, that the scriptures of the prophets might be fulfilled. Then all the disciples forsook him, and fled."

The priest stepped down from the altar and paced. He rubbed and scratched at his chin as he delivered his homilies, as though the emergence of his sermons required it.

"The disciples fled," he continued, stalking pensively. "They abandoned Jesus. This, to me, trumps what Judas did. They forsook him. They ran in Jesus' hour of need. And I think this is so important because how many ways are those disciples like us? Exactly like us?"

The priest paused. "We have some special guests in our midst," he said, beckoning toward the back of the church. "Go ahead, girls, stand up so we can see you." The parishioners turned to face the rear pews. Four young darkhaired girls slowly rose in their seats at Sister Dorothy's command, their terrified eyes like trembling moons. "I would like you all to meet the Truong family. Or rather, what is left of the Truong family. Because these girls lost their mother just a few months ago on their long journey from Vietnam to a refugee camp in Hong Kong. They traveled by night in a boat that you or I would look at and think was just junk, just a big piece of driftwood. They never knew their father, a G.I. who served in the war. They have no one to care for them. In their own country, because their father was a white man, they are pariahs, outcasts. They have been forsaken more times than you or I should ever have to endure."

Apple could not take his eyes off the girls. He wanted to bring them sleeping bags and Skittles. He wanted to make them hot chocolate. He made a list in his head of all the ways he could put them at ease, save them, become their champion.

"When we turned our backs on Vietnam we turned our backs on people, real, living, breathing people," the priest continued. The girls did not seem to follow his words. They continued to stand stiffly in their pew, holding hands with each other, rigid as the carved Stations of the Cross that loomed behind them. "Now, the parish council has volunteered to shelter these children at the parish center until a more suitable home can be found for them. Let us remember Jesus' solitude on the cross as we help these children find their way in this country of ours, which must seem to them to be a very strange place indeed."

Sister Dorothy stood to the right of the girls, and when the priest was fin- 
ished she made a patting gesture with her hand, which meant they could sit down. They nodded solemnly and disappeared behind the Yoost family's fat, disgusting pudding heads. Apple could just see the tallest girl's shoulder behind Gary Yoost, who was a total buttwipe who had thrown a snowball at Apple's face from point-blank range back at the church Christmas party. The girl was wearing a pink T-shirt over a shapeless gray sweatshirt. A shock of jet-black hair streamed in a shining ribbon down her chest. He pored over the brief history of her face in his mind-her slim, solemn cheekbones that framed eyes of impossible, turbulent darkness. He tucked his chin into his chest during the recessional hymn, which was "City of God," really bearing into the kit, and thought of the girl rising up in a summer green field, levitating in her oversized, donated clothes, strands of her hair whipping in the soundless wind like victory flags.

The next day was Good Friday, which meant that from noon until three you couldn't watch TV or listen to the radio because those were the hours Jesus hung on the cross, so Apple went out back to the hammock, because it was ridiculously warm out and Bradley and Hugh were in the boys' room whaling on each other. He lay in the hammock and read A Clockwork Orange, which Fingers had given him for Christmas. He followed the story all right, even without consulting the Nadsat glossary, but his thoughts kept tumbling sideways toward the memory of the girls in the back pew.

"What part are you at?" It was Fingers, peering through the bushes that separated Apple's yard from the Wilcoxes'.

"How long have you been back there?"

"Have they given him the Ludovico treatment yet?"

Apple looked at the book's cover, which was just the words "A Clockwork Orange" in orange on a black background. "I don't know."

"How could you not know?"

"I just."

"You either know or you don't."

Apple had his mouth open but nothing came out.

"Pussy," Fingers said. And then, "Hey, come with me to the lawyer."

"The lawyer?"

"Yeah. To settle this name dispute."

"Where do you-how do you have a lawyer?" Apple put the book down. He started to quake with the old nervousness, that sense, deep within his system, that Fingers was about to get them into something knotty and troublesome. 
"I'm a son-of. They have to see me."

"It's Good Friday."

"Numbnuts, it's a college. They don't give a crap about Good Friday or Happy Tuesday or Suckass Thursday. It's all the same bullshit to them."

Apple looked back at his house, which seemed empty and desolate from where he sat. "I probably."

"You probably should come with me because we're going to get our title back," Fingers said, and started walking toward the convenience store parking lot. Apple tucked the book under his arm and crawled under the chain-link fence that ran around his backyard.

The college was just the other side of Main Street. Gargantuan college kids were out storming the quad, hurling Frisbees and kicking hacky sacks. A hairy girl in an Indian print dress lay on her stomach, listening to Jackson Browne while she underlined passages in a thick textbook with a yellow highlighter marker. Apple hadn't ever been beyond the perimeter of his yard during the time between noon and three on Good Friday. He had assumed that people everywhere were sitting in communal silence, contemplating Jesus' suffering.

They approached a low, serious building on the other side of the quad. "This is the place," Fingers said, holding the glass door open for Apple. They went inside. The receptionist gave Fingers a look.

"Yeah, I'm going to need to see Mr. Lightman."

"Do you have an appointment?"

"Not really."

"Are you a student?" she asked, a sort of condescending doubt clouding up the phrase.

"I'm a son-of."

"Pardon?"

"A son-of," Fingers repeated. "Son of a professor. Of the university." $\mathrm{He}$ looked at her with small, piercing eyes.

The receptionist stood without responding and went behind a fake wood door.

"I made some more NVA regulars last night," Fingers said, nodding, his arms crossed as he stared at the flimsy, brass-handled door, like he might set it on fire with his gaze. "A whole platoon of them, practically. Very convincing. Maybe my best work yet. I made their hats from those little paper circles you get when you use a three hole punch?"

"Cool," Apple said, swallowing hard. He was waiting for campus security to show up, like the time he and Fingers had taken a brown bag filled with 
Twinkies into the woods by the athletic building. Out of nowhere two sedans came skidding into the parking lot, lights flashing, like they were on a mob raid. "Put down the bag and step away," they'd called through a megaphone. Apple was just shy of pissing himself, but Fingers chortled and put the bag on the pavement with a flourish. "Step away," the guards shouted through the megaphone. Fingers and Apple went and sat on the curb. The guards came slowly out of their cars and approached the bag. One of them carefully jostled the mouth of the bag open with his baton. They looked at each other. "Go on, get out of here," they shouted. Apple shot up and sprinted for the convenience store but Fingers stayed put. "Watch out-next time it will be full of shit," Apple heard him say to the cops. Apple kept running until his lungs seized. He collapsed behind the big Korean War memorial rock in the quad. He didn't see Fingers until a few days later. He'd never asked what had happened, and Fingers never told him.

The receptionist returned to her desk. "Mr. Lightman has only a few minutes before an important call," she said bitterly.

"Sweet," Fingers said. "Come on." He cuffed Apple on the neck and pushed him through the door.

Mr. Lightman's office was sparsely appointed with junky screw-on shelves and lightly bashed file cabinets that had promotional calendar magnets all over them. There was just a single picture framed on the wall, which was a line drawing of a man in a tennis outfit bent over, looking through his legs at a tennis ball that was flying away behind him. It was supposed to be funny.

"How can I help you, sir?" Mr. Lightman said, not even in the tone of a question, not looking up from a sheaf of papers in his hands.

"Okay," Fingers said, maneuvering into one of the leatherette chairs that faced Mr. Lightman's desk. "I just need you to clear something up for me. I am making this movie."

"A movie."

"A stop-motion movie, feature-length, about Vietnam. A war film along the lines of Apocalypse Now, only without the boring parts."

Mr. Lightman looked up momentarily. "Stop-motion. You mean like the show with the dog and the."

"Davey and Goliath. Yes. But no. But this is serious. A serious film about a serious subject."

"And you need me."

"I need you because someone else is trying to use the title of my film, claiming it and promoting it as their own." 
Mr. Lightman snorted. "What is the title?"

"Full Metal Jacket."

He went back to examining the document. He was a big man with a rubbery, unpleasant lower lip. "What's that supposed to mean?"

"It's a bullet with a hard metal shell. For piercing armor."

"And who is the other filmmaker? A friend of yours?"

"Hardly. He's a big hairy jerkoff as far as I can tell."

Mr. Lightman snapped the document down onto his desk blotter. "I don't have time for this. Good day to you."

"I'm sorry," Fingers said, rising slightly out of his chair. "I meant no disrespect. For real. Please. Hear me out on this one. This other person, he's using the title of the film even though I came up with it first. So can I sue?"

"Sue." Mr. Lightman chuckled. "That's probably not a good idea and not, I'm guessing, even possible, since your film isn't even finished. Why don't you just talk to this person and sort it out?"

"That's the problem. I have tried to reason with this person but I can't get through to him on account of Warner Brothers Pictures won't give me access to his contact info."

Mr. Lightman frowned. "Warner Brothers. Who exactly are we talking about here?"

"Stanley Kubrick, sir."

Mr. Lightman jerked back in his chair. He looked disoriented. Then he emitted a single, protracted laugh. "Get out of here," he said. "This is a waste of my time. Who is your father again?"

Fingers started to answer.

"Forget it. I don't even want to know. Get out of my face, kid."

Fingers sat back. "That's going to be a tough job, sir, since your face is so fucking fat, you fat fucking whale."

"Get out," Mr. Lightman shouted, rising from his desk to point at the fake door.

Fingers jumped up, swiped a brass pear from the stack of papers it held down, and chucked it full force at the picture of the tennis player, which shattered and fell in pieces into the wire mesh trash bin on the floor below.

"Get-" Mr. Lightman shouted again, cutting himself off as he struggled to circle the desk. His forehead was slick with sweat, and his neck was bright red down the front, like someone had splashed Hawaiian Punch there.

Fingers and Apple got up and ran. The receptionist let out a short, highpitched shriek as they burst through the door and out of the building. 
"Let's split up," Fingers shouted, half out of breath already. "Meet me at the studio later." He peeled off down toward the Physical Plant building, which had a swampy woods behind it and a Star Market on the other side. Fingers sometimes worked there as the guy who collected shopping carts and chained them together in long rows.

Apple ran toward his house until he could only jog, and when he couldn't jog any more he walked slowly, gulping at the chunky spring air.

Apple's family ate dinner fast, like there was someone in the next room waiting to rush in and take it all away from them at any moment. They hooked their arms around their plates to try to protect their portions from each other. Bradley tried to swipe a fish stick from Apple's plate. Apple blocked with his elbow and stabbed Bradley in the ear hole with his free hand. Bradley reeled, clapping his hand over his ear. He yelped and a bunch of chewed-up corn sprayed from his mouth onto the Easter egg centerpiece their mother had made with felt and pipe cleaners.

"Enough," their father called out, smacking his open palm to the table. Bradley righted himself and swabbed the centerpiece with the napkin their mother handed to him.

"We've invited the Truongs over for Easter dinner," Apple's mother said when Bradley was finished. "Your rooms are so filthy I can't even see the floor. So you'll go clean them up after dinner." She cleared her throat, which meant that the issue was not up for discussion.

Apple stared at the crushed fish-stick husks moored to his plate by a listing dollop of tartar sauce. He started breathing fast. He could barely remember what the girls looked like. He had thought so hard and long on the glimpse he'd gotten of the oldest girl's face that he'd smudged it out. All that was left was the dark band of hair that lay across her shoulder. They'd seemed so lost inside their donated clothes-he remembered that. He tried to think about their mysterious journey across the sea in the makeshift boat. How long would it take to get across an ocean? The trip had killed their mother. The closest he'd ever come to that kind of danger was when Hugh and Chris Hamilton put him in a refrigerator box and started whaling on it with sledgehammers. That was nothing in comparison because he could just stand in the absolute middle of the box and not get hurt really bad, but the girls on the makeshift boat, there was no middle they could stand in. The ocean was all edge.

The boys were excused and sent upstairs to clean their room. Apple ran to the threshold and leaped, cannonball-style, onto his bed. Bradley followed, 
jumping off from Apple's bed onto his own. Hugh sauntered in last, hands thrust in his pockets. "This is going to suck," he said, surveying the room. The floor was covered with a jagged spread of magazines, Fangoria and Starlog and Mad and Black Belt and Rolling Stone, their covers half-torn, dog-eared, folded backwards, drawn on and cut up. Disemboweled action figures dangled from strings where the boys had hung and flogged them with mini-souvenir baseball bats. A burned, melted Millennium Falcon sat precariously on the edge of a half-empty fish tank. One whole wall was festooned with gum-card stickers and a Miller Lite neon wall clock that Hugh had found in a dumpster outside the Vital Spot.

"I don't even get why we're doing this because it's not like they're even going to see this room."

"And even if they do," Bradley answered, "how much worse can this room be than Vietnam?"

"That is an excellent point," Hugh said. "You're actually not a complete fucking dumbass, Buttley. I'm kind of surprised."

Apple slipped off his bed and started to gather the magazines from the floor, making a Fangoria pile and a Starlog pile and an Everything Else pile.

"Hey dingleberry," Hugh said. He tossed a Nerf football at Apple's forehead. The impact made his teeth chatter. "Numbnuts. Just kick everything under your mattress."

"Nah," Apple said. "I've been wanting to organize these."

"You're a dick." Hugh flipped himself on his bed and took out a Walkman from the drawer in his nightstand. He put in Warehouse: Songs \& Stories and closed his eyes.

Apple continued sorting the magazines.

The priest arrived in the church minivan with Sister Dorothy in the passenger seat and the four girls in a row behind them, arranged from youngest to oldest. Apple watched through the boys' room window as the priest got out and slid back the cargo door to let the girls out. One by one they emerged like astronauts from the space shuttle, squinting in the loud, white sunlight. Apple put A Clockwork Orange down on the radiator and smoothed out his shirt. He went over to the mirror. He was still wearing the outfit his mother had gotten him for mass, which was a light blue shirt, light blue pants, and navy docksiders. He looked at himself from the side, and wished immediately that he hadn't.

His mother called to him from the bottom of the stairs. It was too late to change. He went down the stairs slowly, like he was entering a pool that 
was super freezing cold. He could hear the priest talking to his mother. As he descended he saw the feet of the girls clustered by the front door. They were wearing those canvas sneakers sold in big buckets at the grocery store, tied together at the laces. It looked like they'd just bought them. The soles were immaculate.

He put his hands in his pockets and walked over to his mother, pretending not to notice the girls. He kept his eyes focused on the floor, straining to bundle his terror in a posture of casual indifference.

"Franklin, these are the Truongs," his mother said, lightly palming the back of his neck.

"Yes, Franklin, let me introduce you," the priest added, gesturing at the girls. "This is Diep-am I saying that right?"

The tallest of the group nodded once and smiled, glancing quickly at Apple. "And next to Diep is Nhung, and the girl in the green shirt is Kieu, and this is Anh," he said, putting his hand on the smallest girl's shoulder. She smiled involuntarily and hung her head.

"The other kids are playing Careers in the living room," Apple's mother said, brushing back her hair. "Let's go in there. I'll make some-do you know," she asked the priest, "if they would drink Kool-Aid?"

The priest shrugged. "Why not give it a shot?"

Apple's mother ushered them all into the living room. Hugh, Bradley, Karen, and Jean were kneeling around the coffee table, the board game spread out diagonally at its center. They stood and backed up against the fireplace to make room for the girls, who stood in the doorway and would not sit down until the priest circled behind them and physically pushed them into the living room. The girls sat down at one end of the couch, their shoulders touching, hands folded in their laps. Kieu and Anh held hands.

"They are adorable," Apple's mother said, and then went to the kitchen to make the Kool-Aid.

The priest introduced the girls again to Apple's brothers and sisters, which meant that Apple had an opportunity to look at their faces without fear of them looking back at him. He guessed that Nhung was closest to him in age, but something about Diep took root in Apple. Her eyes had a sadness-almost like they yearned for a time in the past that hadn't ever really even happened. Just the sensory memory of a warm, defensible outpost somewhere out on the fringes of her experience.

The priest and Sister Dorothy followed Apple's mother into the kitchen.

"Do you play Careers?" Jean said. 
Nhung nodded, and Kieu and Anh nodded after her. But the three of them stopped when they noticed that Diep had not joined in.

"We have other games," Apple said, motioning to the coat closet where the battered, timeworn board games were slotted. He opened the door and drew back his father's many identical trench coats to give the girls a better view.

"Do you want to play any of these?"

Apple's brothers and sisters sat motionless around the coffee table while the girls conferred quietly among themselves. Nhung prodded Diep's forearm with her index finger. Diep stood, smoothing out a pair of baggy maroon sweatpants, and crossed the family room to the coat closet. She stood in the doorway, touching the casing lightly with her fingertips. This was the closest Apple had come to her and she smelled like a dusty mint. Something rough and knotted that stayed fresh against a host of adversities.

Apple ran his hand up and down the columns of boxed games. "Anything. Any of these."

Diep took a step forward and pointed at a faded, chewed-up chess set that sagged under the weight of the other games. Apple nodded and pulled it out. One of the edges got caught on Dark Tower and the whole top tore off as he removed it.

"Oh, sorry," Diep whispered. It was the first time Apple had heard anything come out of her mouth.

"It's nothing. It's old. Stuff happens to stuff that's old."

He pulled the shredded top of the chess box from where it was wedged into the shelf and wrapped it around the game like a taco shell. Diep backed out of the closet in front of him, holding out her hands to take the box, but Apple held onto it. He didn't know why he didn't just give it to her. Maybe if he handed it over he would no longer have this kind of power. He wasn't sure. All he knew was the harrowing tightrope walk from one moment into the next, his heart spazzing out, thrumming his ribs.

He put the box down on the floor next to the coffee table and, on his knees, unfolded the chessboard. Diep knelt on the opposite side of the game board and removed a white rook from the felt-lined cavity where it was stored.

"You want to be that?" Apple said.

Diep examined the rook, rotating it with her thumb. She shrugged and smiled, placing the rook on the game board. Her fingers were long and thin, like reeds.

Apple set up the black pieces, which were made of marble, maybe, or some kind of stone because they were heavy and satisfying to hold. Diep's sisters 
gathered around behind her in a tight semicircle. Apple's siblings went back to Careers. The whole world, for Apple, in that moment, was the whisper of Diep's breath and the tinking of the pawns as she placed them in a row.

Something moved in the background and Apple looked up past Diep's head to see Fingers standing on the porch outside the window, his face blank and open, absorbing the scene in Apple's living room.

"I'll be right back," Apple said to Diep, who crossed her hands in her lap and nodded.

"Who are those people?" Fingers said as Apple opened the screen door and stepped out onto the porch in his brown socks.

"What are you-it's Easter. And my parents." Fingers was not allowed on Apple's property, per Apple's parents, but Fingers would not honor the agreement unless Apple's parents produced a legal restraining order, and even then, he told Apple. Even then. On top of that, Easter was a day for families, so Fingers, who had no God to pray to, was doubly unwelcome on their porch. There was more, though, on top of that, Apple realized as he maneuvered between Fingers and the window. There were the girls themselves.

"Well, you know how much of my left nut I give about your parents, first. Second, who are those kids in there because I don't recall you saying anything about having Chinese relatives or friends or anything even close to that."

"They're not Chinese."

Fingers was on tiptoe, squinting through the window's reflection at the girls. "They're something, though. Something crazy-Japanese?"

"From Vietnam." Apple did not want to tell Fingers where they were from. But he wanted to tell him more than he wanted to hear Fingers guess incorrectly again and again.

"Hmm," Fingers said. He leaned in toward the window. It was too bright to see anything inside the house.

"What are you here for?" Apple said.

"Oh, yeah. I forgot. Hah." He returned his attention to Apple. "I just came up with a solution to our problem. Just this morning. Incredible. It's so easy."

"Yeah?"

"Here's the new title. Full Metal Jhacket."

"What's it?"

"Full Metal Jhacket."

Apple looked hard at Fingers, trying to figure out whether it was a joke. "Yeah but what's."

"See? You couldn't even tell." 
"It's the same."

"It sounds the same, but I added a silent $h$ in 'jacket.' 'Jhacket.' If you listen closely you can just barely hear it. 'Jhacket."

Apple looked around. Across the street, a green station wagon pulled in to the Hamiltons' driveway. A stout man emerged with a pink ham. "I don't know."

"What do you mean?"

"I mean," Apple said. "It's just. People will be confused."

"I don't understand how that could be, since they're two totally different movies with totally different names."

"But what's a jhacket?"

"It doesn't make any difference. Ever seen a clockwork orange? What does that mean?"

"I guess I don't know."

"Ever seen a Krull? Ever seen a Zardoz?"

"But," Apple said, backing up, "those are."

"Answer me. Have you ever seen a Zardoz?"

Apple didn't respond.

Fingers turned around and wiped his chin with his palm. "I wish you would be a little more supportive of my idea, man. All day, when you're at school, or whatever, I'm working hard to come up with killer ideas for this film, and it's not an easy job. Being the idea man. So the least you could do, and I'm talking absolute least, because it hardly takes any effort at all, is to just once in a while say, 'Hey, Fingers, great idea."

The screen door opened and Apple's dad came out, walking fast. He came right up to Fingers until their noses almost touched.

"Out of here. Now."

Fingers grimaced at Apple's father, then broke into a lazy smile. "I was just."

"I don't care what you were just. Get off my property," Apple's father barked as he leaned in to Fingers. His body quaked with each syllable.

Fingers casually turned and walked away. When he reached the edge of the porch he took a sweeping kick at a clutch of yellow tulips in a ceramic planter that Apple's mother had put there before mass. The planter hurtled over the hedge and sailed out into the street, where it shattered.

Apple's father sprinted off the porch and leapt over the hedge but quickly lost sight of Fingers, who knew all the secret back paths through everyone's yards. 
"Get inside," Apple’s father hissed, swatting Apple's shoulder. "We'll talk about this later."

Apple went inside and started walking up the stairs, wanting less than anything to go back into the room with the girls.

"Get in there and entertain," his father whispered, his teeth clenched so firmly that Apple could hear them grinding. Apple slunk down and shuffled around his father into the living room. His brothers and sisters were still playing Careers on the coffee table while the Truong girls watched from the floor where they huddled around the chessboard. Apple could see his father through the window, crouching in the street to pick up the shards of the exploded planter. He turned to look at Diep, who nodded in a way that asked him both if he was okay and if he wanted to keep playing. Her face came to a perfect point like an acorn and her eyes were open and infinite. Apple knelt at the chess board and rested his finger tentatively on a pawn while all the moving parts of the day ground at his guts, mashing him up from the inside like a pestle at a mortar. Diep leaned forward and her hair fell over her shoulder, and it smelled fresh and sharp like crushed camphor. He changed his mind and took a risk with his knight that made Diep smile a little. She tried to conceal it by biting down on her fingertip but Apple saw it and as she took his knight with her queen he felt a surging force inside him, crackling as it ascended through his system, charging him like an incandescent bulb.

"I made this poster." Fingers held an open sketchpad out to Apple, who was sitting on the pile of mattresses as usual. The poster was drawn with colored pencil, and it showed a man's face divided in half. The left half showed the man as a farmer with a straw hat and a red kerchief around his neck. In the background, in partial perspective, were a barn and a sort of cow. The right side of the man was on a battlefield. He wore a helmet and an ammunition bandolier across his shoulder. He was bleeding from the neck. The left half of the man was smiling contentedly and the right half was making a kill face. "Full Metal Jhacket" appeared above in carefully rendered stencil letters, except for the last $t$, which was two bullets crossed.

"What do you think?"

"I like the bullets," Apple said, pointing them out.

"That was a last-minute touch. Sometimes the best ideas come like that," Fingers said, rapping his fist against the length of plywood he'd nailed over the window that had gotten smashed the week before. "You know, on the spur of the moment." 
"Yeah."

"Speaking of which." Fingers pushed at a loose board and peered through the slim crack. "I had this thought."

Something sharp and hot stung Apple's palms, like someone had slapped him there with a ruler.

"I think the movie needs something. I think it needs to be a live action film."

Apple knew what was coming. He knew it. "But we spent so much time making those models."

"I know, I know. We built a lot of stuff for the stop-motion sequences. Do you know how much time Kubrick spent making the sets for 2001? A lot of time. Some of the sets and models he had to throw out. And you know what? He just did it. He just tossed them. Didn't care. You can't hold on to ideas that don't work anymore."

"But we talked about this. How it's not going to look good if we can't get-older people. To act." Apple had just opened himself up for the response he didn't want to hear.

"I'm old enough."

"Yeah right."

"I am."

"Okay, that's one person."

"And those girls, those Vietnamese girls you had at your house."

"They're kids."

"I saw one of them that looked old enough. Besides, the VC conscripted young kids all the time. They had hordes of girls fighting for them. A whole, like, army of them."

Apple struggled to think of a way to change the course of events, but it was like Fingers was pinning him down at the bottom of a murky lake. "The plot," he said, the words cracking and whistling in his throat.

"I did a little rewrite," Fingers said, crossing the floor to the chewed-up card table he used as a desk. He pressed his hand to the cover of a Mead notebook. "Basically, my character gets separated from his platoon, which happens before the actual action begins, so we don't even have to worry about any of that. Anyway, I am out in the jungle, all alone, and I am being pursued by this sniper. A girl sniper. She's like this super sniper, just a machine. A killing machine. And I have to get back to my platoon before she blows my face off." "I don't know."

"What do you mean you don't know? It's perfect. It writes itself." 
"I don't think. I don't think you're going to be able to get that girl in the film," Apple said. He felt light and weak.

"Well," Fingers said, "that would be where you come in."

"No way."

"What?" Fingers turned around fast.

"No way am I going to ask. I'm not-she doesn't even know English, first of all."

"All she has to do is hold an AK-47." He shrugged. "People all over the world know how to do that."

"I would have to ask the priest. I would have to tell him what we're doing. I can't just. And there's no way."

"Come on."

"No, absolutely not." Apple was sure he'd found the silver bullet that would put an end to Fingers' plan. His tonsils bobbed. It felt like they were tapping the base of his skull.

Fingers looked at him with concern. "You're serious about this."

"Yes."

"You're going to let your flimsy religious beliefs, which are founded on a totally gay and ridiculous fantasy, prevent us from making a groundbreaking film that will be remembered forever."

"I just don't want to lie."

"You lie every day, man. Just to live, you lie. And anyway, I'm not asking you to lie. I'm just asking you to ask."

Apple felt a sickness boring into him through his pores. "No," he said, and then breathed a little. "I won't do it. I won't ask."

"And that's it, then?" Fingers crossed his arms and leaned on the desk.

Apple nodded.

"Cool, okay. Cool. Well, I guess we're, hah, back to the drawing board." Fingers pulled the folding chair out from the desk and sat down, exhaling noisily. He opened the Mead notebook and flipped absently through the pages. Apple watched him from his perch atop the mattresses. Fingers pretended to read a passage from the notebook, and then took a Bic from the Gremlins mug where all his pens and pencils were kept and crossed something out.

"You need any help?" Apple said.

"Nah," Fingers said, crossing out another word on the open page. "I'm going to go through this and see if there's anything good we can salvage." $\mathrm{He}$ went back to his fake reading.

"You're not. You're not really reading that, are you?" 
"I'm going to need some time alone to finish this," Fingers said firmly into the notebook.

Apple climbed down from the mattresses and swung down through the trap door to the first floor of the barn. Fingers' dad was down there, removing a tarp from a small fishing boat.

"You," he said. Apple went rigid, assuming he was about to get yelled at, but Fingers' father waved him over with a gloved hand. "I need you to hold this rope for me."

Apple held the rope while Fingers' father climbed up on the boat and worked out a snag. "What's he doing up there?" he asked.

"He's still just. Making the movie," Apple said, looking away at a pile of smashed TVs that he and Fingers had found at the dump. There were a lot of things from the dump in Fingers' barn-an old-time popcorn cart with no wheels, a broken surfboard, half a motorcycle, and a huge picture of the Mona Lisa only Mona Lisa was a Bassett hound smoking a cigar. In anticipation of the coming nuclear apocalypse he and Fingers had been assembling a confusing and comprehensively misleading archaeological discovery for future scientists out of stuff they found at the dump, in the dumpsters behind the convenience store, and sometimes out by the quarry where the high school kids messed around and did it in the slate cave. It started as a joke, but the artifacts came to form a sort of cosmos that told absolutely everything about Apple and Fingers and the precipitous afternoons they'd spent assembling the collection.

Fingers' dad looked up at the ceiling, which was just a bunch of boards and a dangling light fixture. He nodded, bunching his lips into a sort of sucking frown. "You can let go now," he said, and Apple let go of the rope and it went singing over the tarp and into Fingers' dad's hands.

He had the chess game under his arm, and he was wearing an Ocean Pacific button-down that had a picture of a surf van on the back, and he had flecked bleach on the shirt the night before to give it a unique look, but the bleach just turned the shirt pink in places and made it look like a mistake, like something from the irregulars bin or worse, but it was still easily a million times betterlooking than anything else Apple had to wear, even if it smelled a little bit like bleach and even if his shoulder itched where there was still an eggplant-shaped spot of damp bleach and he was so deeply thirsty because it was hot out, and he was on his way to the Parish Center to play chess with Diep.

He slowed as he got close to the building, which was an old Victorian mansion that someone his parents knew in their youth had bequeathed to the 
church long ago. Apple went to Sunday school there every Sunday after mass and also Bible camp in the summers. He knew its columns and eaves like the panels of X-Men issue 94. He had run the lengths of its hallways and hidden in its closets. He'd dozed on its floor in a sleeping bag while Sister Dorothy projected The Lion, the Witch, and the Wardrobe on a tacked-up sheet that covered the wall mural of Jesus riding a donkey into the desert. He had learned the catechism in the same room where the Truongs were situated. It was as familiar a place as anything he knew, its intricately carved balustrade accepting his palm as though he had built it himself. But it was also the line of demarcation between Apple and his friends, who were all something else instead of Catholic, or Fingers, who was resolutely Fingers and nothing else, no matter if he went to hell for it, which he was. Which meant that Apple walked slow as he approached the Parish Center, his gut buzzing like an awakened rattler, hands thrust in his pockets in an effort to radiate a blast ring of indifference out at any spectators, of whom he suspected there were many.

He went inside, slipping through the heavy front door after barely cracking it open. Sister Dorothy sat at the green reception desk in the front office. She was sorting through the mail and she looked up when she heard Apple come in.

"Franklin," she said, smiling broadly. She had a round, soft head that seemed at odds with the sharp, minute features that crowded the center of her face.

"I was just wondering if. I brought chess to play, in case the Truongs."

"Oh," Sister Dorothy said, her face falling abruptly into a vague confusion. "I thought they were at your house?"

"What?" His throat swelled like it was about to burst for real, like someone was stuffing an orange up through his system and out his mouth. His whole chest tingled darkly.

"Diep said they were going to your house to make a movie. Do you mean-are they not there?" Her face changed again, draining of color.

"Oh. Yeah," he said, struggling. "My house. I-I forgot that they were coming over." He backed away into the foyer, nearly knocking down a plaster bust of Mary holding the baby Jesus tight against her. "I'm going to go catch up with them."

"You're sure?" Sister Dorothy said. Her right hand hovered over the pea green phone she used to communicate directly with the priest.

"Definitely. I forgot that was today, is all," he said. He stepped out onto the marble stoop and tried to walk as casually as possible to the corner of Main and Oak. When he reached the corner he started to sprint to Highland Park, which 
was where he knew they were, with all the certainty inside him. He ran as fast as he could, pumping his free arm, slicing at the air like Jesse Owens. Chess pieces slipped out of the box and cracked against the sidewalk as he struggled up the gentle slope of Oak Street, all of his senses shutting down, merging into one primal stream of data that coursed through him like a javelin. A hard, painful nut of mucus formed at the back of his throat as he ran, but he was running too fast to hack it out.

Near the top of the hill his body seized. He doubled over, sucking in whistling slivers of air as though through a pinhole. He bear-hugged the chess set, spilling more pieces onto the sidewalk where they made a plinking sort of sound as they shattered. He couldn't hear anything but his own ragged lungs fighting to draw oxygen. He thought, against his own will because it reminded him of Fingers-rotten, dirty rotten-to-the-core Fingers, the swine-of David Bowman in 2001, bursting from the pod bay door into the vacuum of space. He thought about the gaping solitude of the universe, about what it would be like to suffocate and die out there, his lifeless body tumbling forever into the emptiness like Frank Poole, the other astronaut from the film who was murdered by HAL, his corpse lit from behind by the diminishing sunlight until it disappeared completely, nothing and no one to evidence its presence for billions of years. It must have been something like being on that boat out in the South China Sea, floating in the turbulent darkness, no way to tell up from down.

Apple shook out his legs and kept on up the crest of the hill toward Highland Park. His thighs trembled. It felt like pasty chunks of blood were clotting his veins. He limped under the iron gate that framed the entrance to the park and could already see Fingers out in the unkempt field by the pit that was filled with water and used as an ice rink in the winter. The camera was on the tripod and Fingers was peering through the viewfinder. The girls stood in the high grass several yards from the camera. They were all wearing black karate uniforms and red bandanas tied tightly around their foreheads. Fingers held the tripod in one hand, slowly panning from left to right, and with the other hand he made a patting gesture. Each time he patted the air one of the Truong girls fell, clutching her Gi as she writhed in the tall grass. He turned the camera at last to Diep, who instead of falling over grimaced and lifted an AK-47. She held her pose for a long time before Fingers called the shot. He clapped his hands and approached Diep while her sisters rose from the grass and brushed themselves off. Fingers touched Diep's shoulder and pointed out at the dark, swaying forest that stretched out behind them. He said something to Diep and 
she nodded, smiling briefly. And then he said something else and she nodded again and examined the rifle in her hand. Fingers was moving his arms around like a ridiculous jerk. As if he knew something about anything. Apple started to run again at a full clip. He felt no more pain. His legs did what legs do, without complaint. His lungs flapped like the wings of a swan struggling to lift off from a body of water. He was headed straight for them, like a bullet speeding toward a fleshy target. He gritted his teeth and groaned an ancient groan, and Diep saw him coming first and opened her mouth to say something, but he had already flung the chess board like a discus at Fingers's throat, and it bounced off Fingers' neck and flipped up and open and crashed into the tripod, which fell on the damp grass.

Fingers doubled over and yelped, clapping his palms over his neck. Apple kept coming at him. He thought he was going to run right up to Fingers and kick him in his rubbery, disgusting face, but as he approached he got another idea which was to grab Fingers' goddamned camera and throw it as hard as he could into the pit that was an ice rink in winter. Which he did.

The girls watched in mute terror as the camera sailed through the air, still docked in its tripod, spinning like an earthbound satellite or a bomb. Fingers didn't know what was happening because his eyes were shut tight as he curled up like a pill bug on the dirt patch. The camera went into the muck at the center of the pit and sort of slowly fell over on its side.

For a while the only sound that any of them heard was Fingers wheezing on the ground, broken occasionally by the cheering of a group of parents at a nearby little league game. The girls held hands and stood close.

Apple stepped back.

Fingers rose to his knees, still clutching his neck. Apple watched him slowly open his eyes, blinking against the impossibly bright afternoon sun. $\mathrm{He}$ squinted at the wreck Apple had made of the camera for a long time, massaging the part of his neck where the chessboard had nailed him.

"That was everything. Why did you do that, man? That was my everything. Why did you do that?” Fingers wheezed.

Apple didn't know. He watched the girls take off toward the entrance to the park, booking through the high grass, their red bandanas trailing behind them like streamers from a parade, and he just didn't know. 


\section{The Past, Uncorrected}

Because you seem to want a specific date when everything went down, I am going to go ahead and guess that it was August? It was hot in the cemetery. I had on a tank top. Bats flitted in the canopy, backlit by ruby clouds. That is all. I can't give you exact dates or times because I was not wearing a wristwatch in those days, nor was I paying attention to the news or looking at calendars or any of that. Those were the belongings of another world. I did not experience time. I moved through it without a hint of friction. We were speeding in the gathering dark, already slipping on the schedule we'd made because it had taken Scout extra time to get the shovels from her uncle's shed, because he had a broken collarbone and couldn't remember where he put the keys, and was already reluctant to give her the keys on account of she had lost his wheelbarrow and a chainsaw on previous occasions. The uncle eventually found the keys in a cop-shaped cookie jar on top of his mini-fridge, and, with the sun plummeting toward the horizon, he opened the garage doors to a sea of ruined tools and components. I was parked down the road in the 4Runner because I did not get on well with the uncle. I watched him slowly drag out the rusted carcasses of unnamable machines onto the cracked driveway pavement with his good arm while Scout looked on. She came back with one useable shovel, a hand-held rake-like thing, a pair of hedge trimmers, and a trowel, all bundled in her arms like a cord of firewood.

She already had a sort of rounded hump for a belly.

“There wasn't anything else?" I asked.

"I couldn't tell what the other stuff was," she said, chucking the tools in the back seat. The din upset a cluster of birds settled on the phone wires just beyond the car.

"We need something powered," I said. "We need something that will chew up earth and spit dirt clods."

"He had nothing like that. Now drive," she said, and buckled her seatbelt, which wasn't really attached to anything so I don't know why she buckled it, maybe because the act of doing something was as safe as the thing itself. 
"You have not dug before," I said, squinting to focus on the road in the dwindling light.

"I have dug, but I have not dug this far," she said. "It's true, what they say, right?"

"About the six feet?"

"Yes."

"I believe so. I have no reason to doubt that piece of information, or fact, or whatever that may be that makes people say a thing like that. Why lie about it?"

"I don't know," she said. "It doesn't seem far down enough."

"Lucky for us."

We crept in through the back entrance of the cemetery, the engine practically idling as we rolled slowly through the rows of tombstones, headlights turned off. The night was soaked through with a damp heat. I remember thinking that it had a weight, that place, no matter if you didn't believe in ghosts. The dead were there and they were watching you.

"How much further?" I asked, anxious to get to work.

"Row 7, marker 134," she said. She had done all of the research on account of she had access to a computer at the car rental establishment where she worked. She searched on the Internet and actually found out how to exhume a corpse and use it to stage a crime scene. If you got a corpse that was too old, it would not burn right. If you got a fresh corpse, the various parts would be too easily identified. You had to find one that was just right, and Scout had done this via the online obituaries.

"Did the computer say how many people in history have pulled this off?"

"The computer was all disclaimers-all, like, 'for novelty only,' that sort of thing."

"This is for novelty only? I thought this was real."

"No, they have to say that."

I worked at a factory that made components for shipping pallets that were used to import parts from China that were used to make the machines that made the components we manufactured. I was a floor manager. It was lean fussy work that made me irritable and tired, but I was given a great deal of responsibility over my team and that nearly always stirs up a kind of sideways pride in a person. Here's the thing. The job offered some nice life insurance benefits because at any time of day I could be crushed or split open by the looming machines. Very nice benefits. Then I made a baby inside of Scout. There was not going to be enough in terms of money between the two of us 
to take care of a new baby because Scout made crap and would have to lose her job anyway once that baby came out. So we decided to get at that life insurance money.

We rolled up to Row 7 and Scout turned the car off.

"What is this man's name?" I asked.

"Wayne something. Wayne Malafeew."

I got out and turned on the flashlight. The tombstones were polished and clean, with laser-etched text and symbols. When I go, I do not want one of those things, which come off cheap and forgettable. I'd rather have nothing.

"Oh, here it is." She stood over a small stone set in the ground at an angle. Wayne Malafeew held a small dog in a photograph that was adhered to the stone. He wore a red sweater and the dog seemed to want to be elsewhere.

"Would you want a picture of yourself on your grave? A like candid photograph?”

Scout didn't answer. I don't think she'd decided either way. "You're the professional digger," she said instead. "How do we start?" She got out and reached into the trunk for the tools, handing me the rake-like thing but keeping the shovel for herself. I hastily sunk the tool into the soil. It made a sharp shrill ding as it smashed a chunk of something.

She followed my lead, hitting something hard as well. Her shovel rang out like a church bell. The night creatures seethed.

"You're sure this is a newish grave," I said, whaling on the stubborn turf.

"This is not going to work," she said.

"Let's not start the negative talk," I said, holding my hand out as if I had a superpower. "The only thing negative talk will do is psych us out. It's just hard dirt or something. We can't let that stand in our way. Try setting your shovel down on another piece of ground."

She set the spade down in a different spot and it sunk in. I moved toward her and started tearing at the soil with the rake-like thing. We worked in fluid silence, ripping open a cone-shaped cavity. I watched her mousy outline as she dug. Her belly puffed, strands of her hair lighting up as they entered the shaft of light given off by the flashlight. The sweat that drenched my shirt was getting cold. I put my back into the chore. There was just a smudged swath of dark cloud covering the moon.

I didn't think I'd mind the graveyard, but I did. I didn't take that into account. I felt the stares of a million ghosts trained on my back as I dug. The rotten judging eyes of the dead, or whatever. 
I stopped digging. She looked at me. A clump of hair fell in her face and she didn't brush it away.

"I am just starting to doubt the value of this," I said.

"A hundred thousand dollars."

My jaw started to tremble. I realized I'd been clenching it ever since we left her uncle's place. "If anyone asks me to do this again, one hundred thousand dollars will not be enough."

She stuck her shovel in the hole. "You're delirious."

"There's no way this is worth it," I said, and started to sob.

"The fuck," she said, grunting.

"Look at this hole." I knelt at the cavity we'd made. "We've been digging forever, and my arms-I can barely move, but this hole is nothing. This hole, a baby wouldn't even fit in here."

She shifted in the dark and I realized I had said something wrong.

"Oh come on," I said. It wasn't even as if.

She dropped the shovel and put a hand over her face.

"Hey," I said. I knew I was standing too far away from her, but I was not inclined to draw any closer. I said 'hey' again and she hunched her shoulders. "We're not going to pull this off if."

"That's just what I'm talking about," she said even though she wasn't talking. "This plan is shitsville. I am so mad right now."

A light went on in the white house up on the hill. It could have been anything. But the light went on and Scout took a short sharp breath and froze, and I did more or less the same. The light stayed on. It was too far away to tell if there was anyone peering through the glass. It stayed on and I looked at Scout and mostly I just saw the twin tearstreaks lit by the weak moonlight. I could tell her chest was quaking. I looked at her frozen there by the headstone and I knew that there would be no more digging and so I dropped my tool and rushed over to her. She backed away but I got her over to the car and into the passenger seat.

"We go," I said. "We just go."

I popped the emergency brake and the car started rolling backwards down the path. I guided it down the grade away from the house with the light on, leaning out the door with my foot on the ground. When we got to the bottom of the hill I turned the key and the car started up, louder than I'd ever remembered.

"No no no," Scout said, shaking her head vigorously.

"We've got to get out of here now," I said. 
"The tools."

I started to say the thing I was going to say before she mentioned the tools but then she mentioned the tools and of course there they were still lying where we'd dropped them.

"I'm going up," I said, and I got out quick and started sprinting up the hill. Scout hissed something from where she sat and I was glad not to know what it was. My brain crackled with exhaustion, like fire burning away a cobweb. I thought my legs might stiffen or snap with each stride.

Halfway up the hill I saw a guy. An older gentleman in a terrycloth robe. He stood by the headstone training a flashlight on the hole we'd dug. Our flashlight, damnit. He had his back to me. I crouched and crept backwards down the path, hardly breathing, watching him carefully. The man stooped and, using his robe, lifted the handle of the shovel and examined the shaft with the light.

I put my foot down on a loose bed of pebbles and they went rolling down the hill. The man swung his flashlight around, carving an erratic ribbon through the blue night. I pressed my body to the ground and buried my face in the dirt path. My eyes were clamped shut but I sensed the dazzling flash of the light as the man zeroed in on me. I heard him whisper something under his breath. He came slowly toward me, his slippers crushing the carefully groomed turf. Every part of me was rigid. My dick was contracted way up inside me. If I had to run, I wouldn't be able. I was all locked up. The guy had me. I thought about Scout waiting in the 4Runner and I started to shiver like an epileptic.

"Well," he said, standing over me, "The cops are on their way. You can shake out here or you can come inside."

I didn't understand what he was offering so I hugged the ground to try to forestall the spasms. The more I strained, the more violently my body reacted.

"Listen," he said. "I can't stand to see this. It's awful. Come inside and wait for the cops there."

"I-there's," I said, and then I stopped.

The man bent and hooked his arms around my shoulders. He snorted and sucked in his breath as he struggled to lift and drag me. He had the flashlight in his teeth and its beam danced crazily over the dirt. He lugged me up the path toward the house with the light.

"I'm sorry," I said.

"You can save that for the cops," the man said. I was only apologizing for the fact that I couldn't move, but I guess I was sorry for ruining the guy's graveyard as well, so I let the remark recede into the past, uncorrected. 
The man dragged me to the back stoop and propped me up on the cold paved steps. "You telling me you won't go in," he said, squatting in front of me, his whitened face right in front of me. He was an older gentleman with a creased, stubbled neck and flat lips and he stared at me with a sort of milky dispassion.

"I'm all," I said. My jaw stung-why? "I'm all. I can't move." I took a breath and it came out as a laugh.

The man stood. "I'm done carrying you. You go inside there, I'll make up a pot of coffee. Or we stay out here."

I nodded and tried to get up. It didn't work, but I managed to get myself on all fours. I scuttled up the steps and in through the door, which let in on a sort of anteroom with a washer-dryer combo and a cheap wooden drying rack. I sat on the cracked linoleum floor and looked out into the darkness while the man shut the screen door. I was hoping I would see the taillights of the 4Runner dive down the hill and away toward the state line like we had planned. But there was just the dull, pulsating night.

The man stepped around me and went into the kitchen. He opened a cabinet and took down a brown paper bag filled with coffee grounds. I watched him rinse the clouded carafe and place it on the hot plate. He scooped the grounds into the filter with great concentration.

"So you're the one who takes care of the-"

"Groundskeeper. Yes," he said.

"I didn't know they had those anymore."

"Someone's got to. Not my first career choice, but my grandfather started the business." He spoke with his back to me, taking down a pair of scrappy souvenir mugs from a high shelf.

"A family thing," I said.

He nodded, opening the refrigerator. He drew out a slim carton of creamer and swung the door shut with his foot.

He put the mugs and the creamer on a table in the center of the kitchen. A single lamp with a brown stained-glass shade hovered over the table and I could see only the man's robed chest in its light.

"Sit," he said.

I struggled up from the floor and shuffled across the kitchen to one of two metal chairs set there. The man sat across from me and adjusted his blackframed glasses. His mouth was distracting in its size and lack of dimensionality, looking like two stacked dinner plates. He had a sharp little reflection of the brown lamp in his eyes and he looked at me a long time. 
"What did you think you were going to find down there?" he asked. He sounded genuinely curious.

"I don't know what you mean," I said.

"Sure you don't."

I didn't say anything. I hooked my index finger through the handle of one of the mugs and dragged it toward me. It had an image of the pope rising behind a mountain range. His hand was raised in a gesture of benediction and rays of light emanated from his palm, setting the landscape aglow.

"It's just professional curiosity," he said. The coffee maker made a sound and he pushed back his chair to reach the carafe behind him. "A lot of people trying to dig up bodies, and everyone has their own reason."

I looked at him and he just had those eyes. Sparking little black eyes and an open-mouthed half smile.

"What's the reason you get most often?" I said.

He reached across the table to fill my pope mug. "Oh, I suppose it would be people wanting to put their dicks inside a corpse." He pursed his lips and nodded in anticipation of my reaction.

"You're putting me on," I said.

"You'd be surprised."

I looked out the window. I couldn't see anything out there.

"They'll be here soon, don't worry," he said, and then he huffed a little. I turned back and he was smiling broadly, filling his own mug. "You haven't answered my question.”

"Huh."

"My question. What were you after?"

"Who says I dug anything up?"

He laughed. "I see that ring on your finger."

"What of it?" I said. I didn't look at or touch my ring because there was no reason to do so.

"Gaming the system, huh." He was grinning, really enjoying the company. "You didn't get very far, did you?"

I didn't say anything.

"Most people do get a bit a bit further down than you, but almost no one can dig all the way down. They don't get that it's an awful lot of work. Brutal, thankless work. The kind of labor that makes you question why you do anything at all. Puts you into a kind of existential paralysis, I guess you could say."

I shifted in my chair. I thought about agreeing with him but stopped myself.

"I sometimes think about those Jews who had to dig their own graves, you 
know, in World War Two? By the time they finished they must have been looking forward to getting shot. It must have been such a relief. I put myself in their shoes and think."

Where was Scout? Driving, I hoped. Getting far, far away, across the state line and farther, erasing everything in her wake, never turning back, buffing away the trashy year and a half we took a stab at.

"You're not going to tell me, are you," the man said.

I looked at his rough bluish hands, which he had cupped around his mug.

"Not even if I swear on my mother's grave?" he said and I looked up at him then and he grinned. I about wanted to smash him.

"Sorry," he said, chuckling. "Had to go there. You won't tell me? Fine. It doesn't matter. It's done." He sighed a little and took a long sip. "I know you're unhappy. About this. But I did save you from something worse. Mark me. If you love your wife, it's better this way than the other way. Do you love your wife? If you went through with it, and got the money, it would sear you."

There was a fluttering sound outside, like someone swatting at a window screen with a broom. The man stood and peered out into the darkness. "Bat season," he said, adjusting his glasses. "They're always getting in here. Appropriate, I guess, right?" He approached the window and pressed his face to the glass, creating a visor with his hands to block out the brown kitchen light. Something shifted outside, a foot churning gravel. He stepped back, startled, and ducked down. He slowly placed his palm down on the kitchen counter where a dirty steak knife lay and gripped it without making a sound. There was a muffled swishing out by the stoop. The man crept toward the rear door, holding the knife out at his side like he was in a switchblade duel. I craned my neck and I saw a shape brush through the swath of light that let out onto the stoop. There was a person out there and it was Scout.

The man stopped. Scout's face became visible through the screen and instead of returning his terrified gaze she was looking over his shoulder at me as I reached across the table for the carafe. The man turned back toward me as I swung it, full force, at his head. The glass shattered over his temple with a dull pop like a lightbulb smashing. I held the plastic handle and watched the man fall to his knees. Steaming coffee was everywhere, its stink on everything in the room. The man covered his face with his hands and darkened blood streamed down his naked forearms. I stepped around him and reached for the screen door but I slipped on the linoleum and fell backwards onto his chest. He started shouting, slapping his palm on the floor. I got up and saw that one of his legs was way out of place. Scout opened the door and I came tear-assing out. We 
scrambled down the hill in the unintelligible night, panting like wild creatures. My lungs itched. I was still holding the plastic carafe handle, which I whipped high into the trees for nobody, hopefully, to find.

We charged through the night in the 4Runner. The stars were fixed to the domed sky, lurid and unblinking. It was still hot out.

"So now I'm just driving," I said. I pointed at the road as if the statement needed clarification, which it did, because I was into something clouded and burning, a ruined, ravaged landscape inside of me. My left arm tingled with the sensory memory of the carafe bursting across the man's face. A face that had peered at me with a detached, clinical curiosity just minutes before. It felt awful, but I was unsettled to find that it didn't all feel bad. The taut sensation of the impact was sweet and pungent, the real-world fulfillment of a dream event that I'd failed at since childhood.

"Did he get your name?" Scout asked. She sounded tired and deflated.

"I am pretty sure not," I said.

"Why did you do it?"

I looked at her. "Man had a knife in his hand."

"We could have reasoned with him. We could have talked. I could see right off that he wasn't the. He wasn't going to hurt us."

"You don't know. What you're talking about. He was. There was something wrong with the guy."

"You hit him in the face. You burned him."

Talking to Scout in this way was like playing chess blindfolded. I was just dragging pawns haphazardly across the board for her to swipe in a single, confident move that always put me in check. Anything I thought of, any defense I could mount, she had a neutralizing response.

"I don't know. I don't think he was a real cemetery man."

"David, there was a hearse in the driveway."

I surrendered the conversation by dragging a palm over my face, which was slick with cold sweat. "Thing is, we're now in this deeper than we ever thought," I said. "I know, I know. I shouldn't have done that thing. I shouldn't have hit that man. But that's done. I can't go back and change it. And now we're driving and what are we supposed to do?"

"You're the brilliant criminal mind."

I slapped the wheel. "You're the one who came up with this plan. That was you with your Internet gravedigging stupidity."

"You're crap." 
There was no more talk between us as we plowed through the cake-like night. Scout put the seat down and tried to curl into a sleeping posture. I put my right hand on her calf and she did not move her leg away. I ran my fingers from her knee to her ankle while she drifted into a sort of bunny sleep. Everything in the car was relatively safe, and would continue to be safe as long as I kept us in motion. When she was out I reached up to feel her abdomen. I slipped my hand under her tank top and felt the curve of her belly where the baby was forming. Close to her hip I felt a pulse. I had no way of knowing whose pulse that was. I withdrew my hand and shuddered.

I drove the 4Runner until the tank was nearly out. We weren't anywhere. I had seen no gas stations that I could remember. I tugged at Scout's ankle to wake her. She lifted her head and peered around through barely opened eyes.

"We're almost out of gas."

She put the seat back up. "Okay. Why didn't you stop?"

"You were asleep. And I wasn't out of gas when we passed the last station." "Ugh," she said, rubbing her eyes with her palms.

"As I see it, we could stop the car and I could go get gas on foot."

"I don't like that plan."

"We could just keep driving and hope that we find a station."

"What's that?" she said. There was a square of light in the distance, hovering above the road.

"Let's find out."

As we approached we saw that the square was a motel sign. It said "Plantation Inn" and the reversible placard underneath read "Vacancy."

"Let's pull in here," I said. "I have some cash. We sign in as the Smiths and get some sleep. Tomorrow I'll go find gas."

Scout nodded and I swung the car into the lot. I parked in back of the motel, which was an angular, pinkish assemblage of rooms that let out on a common balcony.

"I'm staying in here," Scout said, folding her arms.

"Yeah," I said. I took a look at my face in the rear view. It looked bad. I wet my thumb and tried with partial success to scrub out the tiny flecks of blood that peppered my cheek. I faced Scout to get her take but she was looking away out into the empty lot, choked at its perimeter with low-hanging trees and unkempt brush.

I got out of the car and started walking across the lot, which was doused in a gross orange light. Huge bugs rammed their bodies into the gooseneck lamps, 
spinning and careering into the night on impact. I turned the corner. To my left the lobby of the motel glowed amber through the floor-length windows. A dark-skinned woman with a shawl sat perched on a vinyl stool behind a woodpaneled reception desk. She read a foreign newspaper with text that looked like ribbons of spilled, splattered ink. There was the glass door of the motel, framing the case of tri-fold pamphlets that hawked area attractions and the candy dispenser half full of dime-sized sours, and just beyond, the woman reading the paper, and then there was the road leading away into the shaded distance. I did think, then, about what the man in the graveyard had said, about how he had saved my relationship, but the thing I decided to do next would seem to contradict him. 


\section{Thirty Years of Prosperity for Every Fifteen Years of Hard Work}

Pebbled strokes of black ash crowded the sills of the tenement where the cosmonauts lived. Bitter upcroppings of air from the south sailed mournfully through the cracked eaves of a building that was new just ten years before, but which was already indistinguishable from the bombed ruins at the border of Elevengrad on the Eastern Front. A clutch of boys in blue coveralls cleared away the dust from the courtyard with tiny whisks, moving slowly backward on their haunches, dark blue bandanas tied tight against their mouths. A bulb went on in a room on the second floor, throwing a messy block of light across the boys' path. There was a head silhouetted in the window, which the boys dutifully ignored.

Rozhko watched them work from his window, their hunched backs swaying slowly in the ruined dusk. He'd just woken from another spacewalk dream. He'd stripped out of his pressure suit as he floated away from the capsule, his limbs petrifying as he leapt into the unfathomable darkness. But like the drowning man who flails toward the dwindling marbled light of the sun as he's dragged down into the abyss, the urge to look back at the Earth overtook him. He turned awkwardly in the void to face the luminous globe. On its surface he could see his tenement with alarming clarity, its frame listing, crumbling like a soiled fruit. Somehow he could even make out his son, who determinedly kicked a rust-colored ball around on the worried plot of dirt along the side of the building. He watched his son until the tenement took up his whole field of vision and he realized he was tumbling through the atmosphere. He smacked the empty basin of the Fountain of the Four Virtues of His Almighty Excellence and the shock woke him. He rolled over on his other side, having heard that a person could empty his head of a bad dream that way. When that failed to calm him he slipped out of bed in an effort not to wake Vera and went to the window where he cranked his hand lamp until it went on. He watched the boys clean the walkway, going over in his mind all the details of the dream, 
sorting out what was real from what was impossible. He knew that he would not be able to see his tenement from outer space, but he also knew that his weekly trips to and from the Tiomkin IV were staged for the Glory of the People, that he only sat inside a simulated nosecone in front of a battery of primitive television cameras, eating yogurt from a tube until he was told it was time to leave.

He heard the grating shuffle of his son moving down the hallway in a poly nightsuit. He stared at the curved orifice of the door where Yegor's shape crystallized in vague, gray stages. The boy stood at the threshold, his shape rustling in and out of focus like a curtain agitated by a hot wind.

"What is the problem?" Rozhko offered in a windy, breathless burst, training the hand lamp on the boy. The words softened in the darkness-the end of the sentence went cottony and dim.

Yegor stopped shifting his weight in the sudden light and began to cry silently.

"You can't come in here," Rozhko said.

"I know."

"We talked about this."

"I know," the boy said, raising a shaky hand, palm out, to show that he knew and that he didn't want to talk about it again.

"If you come in here now you will never learn to be alone. And if you never learn to be alone, your life will be very difficult."

"I know," Yegor said with the hollow wheeze of a boy who's had the wind knocked out of him. He continued to stand at the threshold, gripping the molding for balance.

"You can find your way back to your room, I suspect." Rozhko felt the springs on the bed shift slightly.

Yegor rested his head against the doorjamb. "What if I pick the wrong room?"

"You're seriously worried about that?" Rozhko said, but before he could finish the sentence Vera rose from the bed and took Yegor's hand. The two of them disappeared in the garbled dark, nothing left in the spotlight of Rozhko's lamp but a griddled square of carpet. The cosmonaut felt a familiar dread metastasize coolly throughout his chest. Vera stayed in the boy's room for the remainder of the night. Outside, two warships circled the central tower. Rozhko watched their lights blink in spastic unison until they merged with the purple sky, and then it was morning. 
Rozhko took the tube out to the training facility where he was scheduled to meet his replacement, a putty-faced boy from the Fourteenth Honorable League of Defense. Morse had whistled when he handed over the charts on the boy in a way that meant Rozhko was in trouble. "This young man can barely cut wood, let alone buckle a seatbelt," Morse had said, backing away from the counter.

It was an outrage that Rozhko was being replaced. The dailies had him at third place in the popular vote. He lagged behind Kravchik, sure, but no one could beat Kravchik. The way he handled the controls, the seamlessness with which he simulated the experience of real spaceflight, approached the unreal. He did delicate little things with his hands that no one had ever thought of. He literally advanced the form. His dexterity and grace were unmatched. Paraskova was in second place. She was the daughter of a pinch-faced barrel merchant, which got everyone worked up for all the obvious reasons, but she managed to exude a cool and even temperament that showed she'd risen above her station. She didn't make anyone feel guilty, even with her overly stocky torso and trademark sallow complexion. But her work in space was nothing extraordinary. She had method but no passion. Her range of motion was weak. There were six cosmonauts below him in the charts, including Karpov, but still he was the one being mothballed.

The tube hit something, probably a body, which sent everybody tumbling violently into the aisle. Once or twice a week the train would hit a floater. All of the papers in Rozhko's pockets spilled out on the corrugated floor in a ragged fan pattern.

He scooped the documents up to his chest, cradling them like a newborn animal as he returned to his seat, readjusting the stiff brim of his top hat with his free hand. Once the train started moving again, he carefully unfolded the latest letter.

"Dear Father, I'm almost done with training. Can you believe it? Yesterday they took me up into the ionosphere for an anti-gravity simulation. It wasn't what I expected. I thought it would be easier to tell which way was up, but I lost that sense right away, as soon as we hit the crest of the arc. Is that how you feel when you go up? I am dying to know if it is something I inherited from you. My father here has never been in space. He makes those murder kits for girls. I don't know if you have them over there. I think I heard that murder is still outlawed where you live. Anyway, next month we graduate, and then we have a vacation week, and then I am going to Calisco station. Will you still be in orbit then? I know we wouldn't be able to meet in person, with all the laws 
against it, but it would be the closest we'd ever been to each other. My parents here don't like it that we're both astronauts, but I do. Yours, Galina."

Galina was Yegor's twin. When the two were born, Rozhko and Vera were forced to choose only one to keep, and he thought the boy would be more useful, so they sold the girl and used the money to put Rozhko through cosmonaut training. It became more and more clear he'd made a poor decision. Galina sent letters regularly, detailing her space training in a country that could actually afford space travel, while Yegor stunted and gnashed in Rozhko's living room, growing solidly into his form and aspiring to little else. Galina's letters came every month in an exotic, long envelope made of fine red paper, marked with erratic, faded stamp work. Opened, of course, by the Ministry of Correspondence, and censored wherever necessary. Rozhko would take them into the washroom, slide the footstool in front of the door, and read them by candlelight. Vera was not interested in the letters, and she hated that Rozhko read and answered them. The memory of Galina was like a meal she wished she could swallow and expel. It wasn't her choice to keep Yegor.

Rozhko folded the letter hastily and slipped it in his breast pocket with the others.

The auditorium went dark. On the screen a single white dot appeared. A confident voice issued from a threadbare speaker cone somewhere in the back of the auditorium. "Space," it said, "they can do it-why can't we?" The dot became larger on the screen until it became clear that it was the exhaust from a rocket. The ship came closer and closer, revealing three figures in the cockpit-three serious men with close-cropped hair. "Seems like an unattainable goal, doesn't it? Yet here at the Yuri Yushkakov Center for Agriculture, Public Welfare, and Interplanetary Exploration, we're setting the pace for space travel across the globe. Within the past five years, we've conducted successful missions to the nearest three heavenly objects, without sacrificing our dedication to the thriving community of agronomists working day and night for the glory of the people and His Almighty Excellence."

Rozhko stood at the back of the auditorium, waiting for his eyes to adjust to the impenetrable darkness.

The film ended and the lights went up. He found Ekar by the water trough.

"Rozhko, I don't need to tell you how sorry I am," he said, smiling bitterly, grasping Rozhko's shoulder with an intimate aggression. It was an excessive but heartfelt gesture, which was why Rozhko couldn't help but admire Ekar, even as he was likely the one in charge of phasing Rozhko out of the program. 
"It's not-it's nothing. We all have our day."

"According to His Almighty Excellence, yes, I suppose so," Ekar said, his face frozen taxidermically in the smile.

"Where is he?"

"Oh," Ekar said, stroking his chin. "Your replacement. Follow me."

Ekar led Rozhko down a narrow, unlit hallway that led to the first-year center.

"He's not a first-year, is he?"

"First-year? Well-"

They approached the nosecone simulator. Inside, they could hear a young man's voice. "This is the cockpit," the voice called. "Wow. I can't believe this is really the real cockpit."

"Aksak," Ekar called abruptly, "you've a visitor."

Rozhko's replacement emerged from the nosecone. His face was flimsy and boyish, only barely featureful. The head was a hastily rolled fleshball in which two glaring eyeholes had been poked. The mouth, too, seemed gored by a small child's hand.

"I've seen this stuff, right?" he said, as though introductions had already been made. "On television-a hundred times. A thousand hundred. Everything's so different in color, though. I never knew these buttons were colored."

Rozhko flinched. "Don't touch those, please-"

"I mean, and these switches-they're red. I always imagined them like I saw them-just like, a medium grayish tone, sort of. But they're red!"

Aksak continued to circle the nosecone, handling every surface that would accept touch. Rozhko trailed close behind, righting all the controls, returning the valves to zero, shocked at his own attentiveness. The cockpit had been the subject of derision for so many years-on off hours, during His Almighty Excellence's fireside primers, Rozhko and the other cosmonauts would moon the camera crew from the thick blast windows, their asses white and hairless against the tiny portholes. As soon as the station went off the air for Unity Hour, they'd unzip their coveralls and play speed rounds of euchre, just because they could. Just because they knew that, inside the safety of the capsule, they were the only people in the entire nation who were naked. He found himself suddenly possessed of a crippling reverence for the space.

They crawled inside the cockpit. "There are the breathing tubes," Aksak said, pointing at the breathing tubes. "Those are the breathing tubes that you had to use on mission sixteen. That's incredible. What was mission sixteen like? Did you really almost choke?" 
"No."

"Didn't you-I thought you threw up at one point, and everyone was worried that the gravity simulator would go off so that your barf would go flying around the room in little particles."

"I performed an expectorant simulation, if that's what you're asking about. Please, don't put your hands on those-people have to mouth them."

"Were you scared you would die?"

Rozhko looked closely at Aksak, searching for a cue that would let him know the boy was tugging his chain. But he saw only earnestness and wonder.

"What do you mean when you say 'scared'?"

"I mean, I was totally scared for you guys. Especially you, on account of your vomit. Being out there in the blackness, sick, losing air, not sure whether you were going to be able to reenter the atmosphere. I was up all night watching that with my dad."

"But you know it was a simulation. You know that all of this is predetermined."

"Like, you knew that you guys should instantly open up the red book and go to plan 11A?"

"No, I mean-"

The boy actually believed. The spectacle was complete-the illusion had been transmitted seamlessly from the actors to the audience, and now the reality he'd created was stronger than the reality in which they were living.

He stood at the threshold of their flat, the open door flooding the narrow corridor with dusty afternoon light. The only sound was the riffling of fabric against fabric punctuated by the occasional grunt. The air had a thickness that said to him that something was not right. He entered the living area. Vera was on her hands and knees in yellow coveralls.

"Yegor is stuck behind the reception screen again," she said between labored tugs. She had hold of Yegor's sock foot, and he was vigorously kicking against her grasp.

Rozhko knelt at her side.

"I can do this," Vera said.

"I'll get the other leg."

"If you would just let me take care of this," she said, but Rozhko ignored her, taking Yegor's other foot. Yegor increased the ferocity of his thrashing. He kicked out like a mule, which dislodged him from the reception screen. The three of them crashed backwards onto the floor. Yegor stood up first, a ragged 
swatch of blood marking his forehead. He gave his parents an accusatory stare before retreating to his personal living area, where he crawled inside a packing box he'd decorated with the insignia of the People's First Tank Brigade.

"What is his interest back there?" Rozhko said, forcing the reception screen back into position with the furnishing winch.

"He thinks the people on the screen are actually standing behind the set. $\mathrm{He}$ thinks he'll find a tiny version of you back there," Vera said, struggling up from the floor. Rozhko knew he should feel ashamed that his own son would entertain such ludicrous theories just to make a connection with him, but instead he felt only pity for a boy who clearly was not cut out for the world, not like his sister, who was preparing to make the flight Rozhko himself had been making in pantomime for the past thirteen years.

"My Dearest Galina," he wrote, and then struck a line through the salutation. He started again-"Greetings, Galina," he wrote. He tapped the tip of his pen across each of the letters of her name. Then he crumpled the sheet, tearing it from the notebook in the process, and started on a second, clean sheet.

"Dear Galina," he wrote. "What I have to tell you is not easy. Hard as it is to believe, what I have to tell you is more difficult than the decision to give you up to the Traffic Ministry so that you would have a better chance in another country. When I think of it, I didn't feel so bad, bringing you there. I really thought it would be better for you. I just didn't anticipate the sucking circumference of the hole it would leave in my life. Now I know, and this letter, this confession, is-"

Rozhko stopped and put down his pen. He found that he was breathing rapidly, and his throat had swelled so that he could barely take in air. His face made a whistling sound in the empty room.

"So, you're telling me I should not pull the lever all the way back?"

Rozhko and Aksak were in the cockpit again, going over the launch sequence.

"You did hear me when I said 'ease the lever back to the midpoint,' right?"

"Okay," Aksak said, looking sternly at his own hand, gripping an imaginary lever. "Can you tell me, will I get to do anything dramatic on this mission?"

"It's your first mission."

"So?"

"So, nothing happens on the first mission." 
"Okay, but how do you explain Geicho?"

"Geicho was inevitable. Geicho's situation-he had to be jettisoned."

Aksak hunched in his seat. His eyes, half-hidden by black tufts of eyebrow hair, seemed too small for his head. "It's just-what am I doing, you know? If I'm not even doing anything-if I'm just a guy going up and down in a fancy tube?"

An unexpected rage spiked in Rozhko's brain. He felt a strange urge to protect the discipline he'd held in disgust for so long. "Who are you, saying these things, baldly, right inside the cockpit? You've never been on a mission before, Private. You're not Geicho. You're not even Kirnov."

"Whoa-hold on. Stand down. What are you suggesting?"

"You're a nobody calling into question the methods of the greats."

"Choice words, coming from an expired-" but Aksak stopped, focusing on a point just beyond Rozhko's head. He slowly rolled his tiny eyes back toward the display screens and coughed. "Sorry," he said to his fingers, which nervously caressed the launch sequence indicator buttons. "Sorry about that."

"I hope so," Rozhko answered.

The story he gave Vera was that he was taking Yegor for a walk by the old park. Vera did not like this idea, being that it was so close to curfew, and that so many boys in the neighborhood had been raped or abducted and sold overseas. Rozhko worried about these things, too, he reminded himself as he walked hand in hand with the boy, steeling himself against the frigid wind, but he needed to see Zadora.

There was little to see in the park since play had been abolished during the last Great Push. The elaborate concrete climbing structures, each modeled after animals at the nearby zoo, had been razed when viewing creatures for pleasure had been outlawed. The structures were sawn into boulder-sized chunks and buried, leaving only a series of crumbling oblong bases and, occasionally, the tragic carved concrete head of a shattered Bengal tiger rising through the leathergrass.

"What are they teaching you?" Rozhko asked as they stepped over a giraffe's snapped neck.

"Sums," Yegor responded distractedly, dragging one foot theatrically behind.

"Really? You're on sums now? Give me a sum."

"Sums aren't something you give. They're something you take."

"Okay, add five and five." 
"Why?"

"Just because. Otherwise we're just walking."

"Five plus five. Eight."

Rozhko looked away, grimacing.

"I can do sums, Father," Yegor said sharply, withdrawing his moistened palm from Rozhko's grip. "I do them my way, but I can do them."

They arrived at Zadora's flat. Zadora had told Rozhko to knock four times when he arrived, and then to go immediately over to the hole where the fountain had been and wait. When he saw a light flicker in Zadora's right window, he should approach the door again.

"You'll need to wait here," he said, pulling the drawstrings tight on Yegor's snow suit. "When the light goes on. You'll stay here and wait until I come out."

"What if I get stolen?"

"You won't get stolen, but if anyone approaches, just start yelling and I'll come running out of that house."

They stood by the hole for a good twenty minutes. Rozhko hopped from foot to foot. Yegor balanced on a toppled pillar. The sky was heavy with stars. The light went on and then off again.

"Is that yours?" Zadora said, peering out at the boy's silhouette when Rozhko arrived at the door.

"He'll be fine. He's big."

Zadora had told Rozhko not to say anything as they made their way into the clay pit. At the other end, in a tiny receptacle chamber that accommodated two kneeling men, there was a single television monitor draped in cheesecloth.

Zadora removed the cheesecloth like a bridal veil and pressed a button on the face of the television. An image slowly emerged from the lazy cathode array-a stretch of luminescent tundra, clutches of snow whisked up in conical eddies at unpredictable intervals. It looked like late afternoon. A group of vehicles appeared over the horizon-three or four compact vehicles with riders. Behind the first group, a second, larger group emerged. It became clear that the vehicles were a sort of four-wheeled motorbike, and that the drivers were all women, completely naked except for athletic sneakers, red knee-length socks, and red batting helmets. The camera receded as the motorcade drew closer, revealing a cove packed with seals, all struggling to move out of the way. The riders reared up on the vehicles as they approached the cove. With expressionless precision they jumped the lip, landing in the seal pile in a vicious, well-orchestrated convoy. Wild jets of blood doused the drivers. Rozhko had 
trouble processing what he saw. He took in the images, could understand what he was looking at on a basic level, but couldn't link any of the elements together in any meaningful way.

"This is a program?" Rozhko asked.

"Yes, this is prime-time. A very successful program over there."

"Any idea what it's about?"

"None. I can't always get the soundtrack. I feel I'm missing some crucial information. These women were apparently imprisoned earlier in the show. I don't want to speculate."

Rozhko looked at his hands to reorient himself. "How are you able to do this?"

"Everything is happening at once in the sky," Zadora whispered.

"And the launch, my daughter's launch-I will be able to see it?"

"If all goes as planned. The governmental programming there is often preempted. The other day, a presidential speech was canceled to make way for the premiere of a program about sport exhumation."

"You could be so easily killed for this. Not just killed-I can't even imagine."

"Eh. Talk to me about something interesting." Zadora had spent twelve years at a camp in the north where he was regularly put in a small concrete box for days on end.

"What will I owe you?"

Zadora shut off the television as one of the women held a seal carcass up above her head with dramatic fury. "You would never pay back what you owe, so I'm giving it to you for free. Be here on Workday Four evening. That's when your daughter's launch is scheduled."

"Yegor, please get down from there-chairs aren't meant to do that."

They were sitting in the commissary at the Table for the Glorification of His Almighty Excellence's Twelve Resplendent Theses. The cosmonauts were allowed to sit at the table with their families on the night before each mission as long as they left an empty seat for His Almighty Excellence. Rozhko forked down his meal with deliberate precision. They'd rescheduled the mission for Workday Four, so that, while he sat in the Styrofoam cockpit of the Tiomkin IV, shaking in his chair on the makeshift set, his daughter would actually be launched into space, the details of her face remaining a mystery to him. Vera sat across the table tinkering with her utensils. Yegor slumped at Rozhko's side, stroking the outline of a lion into the shallow pool of gravy on his plate. 
Down at the other end of the table Aksak sat alone, contentedly forcing down spoonfuls of hardened rice.

"This is the last time we're eating on wood," Vera said, looking down at her food, largely untouched.

"Don't say that. You don't know that. We're nearly halfway to the years of prosperity."

"Rozhko, you know nothing will come of it. What did we get out of the last age of prosperity? Ergonomic broom handles. An extra soy cake a month."

"I suppose it all depends how you measure prosperity," he said. He found her distress repugnant and childish.

"You're being put away. How soon do you think you'll be forgotten?"

"Forgotten? I believe I appear in my son's own history textbook."

"You'll fade," she said resignedly. "You'll fade. You're fading already."

There was a dull, rubbery crash. Yegor had overturned his tumbler onto himself. Rozhko and Vera turned in unison to see the boy frozen in place, his back arched against the seat, left hand gripping the tumbler's handle. He looked dazed, as though he'd been tasered.

Rozhko stared at the boy evenly. He had no intention of acting on his son's behalf, even though he was sitting close enough to blot the spill with a canvas napkin.

"Clean it up-do something," Vera said urgently, rising up from her chair.

"Do something? It's just water. When I was a child, my mother spilled maple syrup on my lap, and it was winter, and the syrup froze, so that my pants were stuck to my thighs. I wore the pants until spring thaw, so tell me why I should worry about this?"

Vera stood quickly and crossed to Yegor's side of the table. "I can't even begin to imagine what's made you into such a monster." She picked the boy up by his shoulders and set him on his feet and then moved with efficiency toward the latrine, training her eyes on Rozhko. It was a look that expressed the general closing down of possibilities.

A group of shirtless men worked the riser that lifted Rozhko and Aksak to the elevated grid that circled the nosecone of the Tiomkin IV. The cosmonauts turned toward the camera crew below in the manner they'd been taught in the training sessions and walkthrough exercises, waving to the imaginary crowd, their backs to the sweeping blue skyscape that would be keyed in behind them by the men at the machines. 
"It's a beautiful day, isn't it?" one of the squarish, severe anchormen said to the other in another part of the soundstage.

“Amazing. I wouldn't be surprised if somewhere, somehow, our leader hasn't built us some sort of weather machine-type device, something that fires up a column of sunlight whenever we need it most."

"I don't mean to interrupt-they're just getting into the capsule," the first anchorman said, tapping the other's forearm.

"The capsule that will take them to the stars."

"And beyond."

"Let's watch."

Rozhko stepped aside to let Aksak into the capsule first. He watched his replacement fit himself through the crimped aperture of the portal. Every moment he allowed to advance before him was a moment in which the possibility of watching Galina pierce the atmosphere diminished. The worst of it-the part that made him choke with rage and embarrassment-was that she'd see him in this footage, waving solemnly just before he entered the cockpit, and she'd believe that he was headed to the same place. Maybe she imagined they'd pass by each other when in orbit-two people who couldn't possibly be further apart grazing momentarily by each other, waving through thick, misted portal glass, nothing-literally nothing-between them, for a full forty seconds, a minute maybe.

He entered the cockpit and took his seat. A team of men in orange cloaks followed, buckling him in and hooking up the pressure valves to his suit. He looked over at Aksak, who was gazing up through the blast glass at the tungsten light array that made daylight. Aksak was trying with great difficulty to stifle a wide, boyish grin.

"This is it," Aksak said, fiddling with the arm of his chair. "This is what we've been training for. Were you this excited when you first went up?" He turned to Rozhko, who returned his glance with a hollow, vacant face.

"I don't remember," he said after a long pause.

The technician radioed in to let them know that the launch was beginning. Aksak started to cry silently.

Rozhko put his head back in the seat. The voice on the radio was aggressive and tinny, shouting down the seconds. The tungsten bulbs bore a cloverleaf pattern into the center of his vision. Galina, somewhere, was zipping herself into a pressure suit. The thought flushed Rozhko with a darkness. He took a single, world-inhaling breath, and began methodically removing the seat buckles. 
Aksak looked over, snapping instantly from his reverie. "Whoa, whoa-what are you-we're about to launch, you can't ... we'll crash-you ..."

Rozhko was out of the chair, tearing off the pressure valves, which flailed like angry, weightless cobras in the tiny cockpit. The portal door only opened from the outside, so he knelt by a flimsy control bank and began tearing at the cheap fiberboard and vinyl.

"Holy-you don't-" Aksak was halfway through unbuckling his buckles when Rozhko had made a hole big enough to fit through.

"Enjoy space," he said, lowering himself hastily into the crevice. "You've never experienced anything like it." He slid himself down into the hole until all Aksak could see was the top of his head. Then he lost his grip and fell straight into the hollow cavity of the rocket. On his way down he glimpsed Aksak's head peering through the broken hole.

He landed in a cloud of musty batting. His legs were immobilized by an unseen beam. He thrashed in the blackness, dinging his forearm on a corrugated aluminum pipe. He was stuck. They'd have to tear open a wall to get him out. He would not see his daughter. The program was likely already over. In the darkness, he could no longer tell which way was up. He let out a desultory hiss-in all his years of space travel, this was the closest he'd come to experiencing weightlessness. He knew it with a tactile precision, the way the blind knew Braille. He'd first felt it long before the space program. Back in the hazy, solitary years before the children, back when he worked on the lava barge in Tronsk. He was gone three weeks out of four and when he returned he would sit quietly with Vera in the dim kitchen at night, drinking cadmium tapwater while the tube light flickered angrily, Or maybe they'd go following stray cats in the park during free hour, her arm docked in his. Everything was ahead of them then. The future was an untamed thing, theirs if they wanted it. $\mathrm{He}$ remembered coming back after a particularly grueling extraction in Barkabos. The apartment they shared was soft and still and filled with dying light. He removed his groin parka in the hallway, bracing himself with one hand against the white wall. He ached to see Vera. His hands, in those days, were like divining rods, always trained on her, no matter how far away he traveled. But there would be time, he thought. There was all this time to hold his Vera. He unthreaded the nylon cord from his coccyx ring and removed his elephant boots, and when he looked up again, he saw her, framed in the doorway to the common room, her gown illuminated faintly by the light through the windows. She offered a nervous smile. He found a streak of fear in her face and he knew immediately that she was carrying. 
"How long have you been wait-" he said, holding a single boot with both hands, like an offering.

"Waiting to tell you? For three days now."

"But that's-that's-"

"Oh Rozhko," she said, as if she were coming toward him for an embrace. But she stood in the door frame. "Please be as excited as I am. Please be even half as excited. I'm already imagining all the little uniforms the ministry will be sending us-those little red books," she said.

Rozhko dropped the boot and came toward her. He threw himself into her, burying his face in the crook of her neck. His eyes stung and he started losing air.

"Why are you doing that?" she whispered, running her hands down his back.

"Can we really be expected to take care of a child?"

"What?" She pulled back to try to get a look at him.

"Think of all the things that could happen to a child, even before it's born. There is almost no way it could work. The odds are against us."

"Why do you say that? How can you say that? We've talked about this-we've gone over it so many times."

"I know," he said. He shuddered, weeping heavily. He clawed at her shoulder as if holding on for dear life.

"Aren't you even a little happy?"

"I don't want to be happy."

Her face went small.

“Look. I don't mean-it's just that, this happiness, such as it is-what if it is the arrow that pierces the future, ruining everything? I need to hold it off until we are safe."

She struggled to pull away from him, put a hand to the side of his face in what might have been the last real point of contact between them. "It's true-terrible things could happen. But even if they do, you won't have wasted your happiness now. Happiness is not a resource-you don't understand this?" The logic of this statement worked its way into him virally. He wanted to believe what Vera said, and for that moment in the hallway, he could see his happiness as something timeless and immortal, not the scraps of something cached in a dark hole. And in spite of the arrow he feared would soon puncture the fabric of his life with Vera, he allowed himself to brim with happiness. He felt breathless and light, like a large man was standing behind him, lifting him up by the lungs.

It was, he realized as he lay in the cavity of the model rocket, staring up at Aksak, the sense of weightlessness he'd been miming ever since. 


\section{Yeti}

"It's hot," Dombal said, and it was the truth, but Murph just kept looking at the yellow dumpsters and ate his sandwich, which was lettuce and pickles folded into a single slice of bread because that was all Murph had left in his apartment. Murph was a person who didn't answer your questions; he didn't respond to your requests. He did what he did and sometimes it coincided with the thing you wanted him to do and those were the lucky days. Like, Murph's job was to remove the grilles from the heating units that ran along the back wall in each dorm room, and Dombal would follow behind with the vacuum, clear out the decades of balled hair, dander, condom rot, and animal bones from between the blades, and replace the grille. Some days Dombal would enter a dorm room to find the grilles removed with precision, carefully laid out on the floor next to the heating unit, screws collected in a paper cup on the windowsill. Other days, the grilles would be buckled, wrecked, twisted in an upward arc from the heating unit as if yanked by a powerful monster. There were days when Murph slept all day in the top bunk of one of the dorm rooms and left the grilles untouched, and Dombal would have to remove them himself, which was bull because he was the cleanup guy and Murph was the takedown guy, but Dombal didn't want to have to explain to Bill, the Physical Plant shift manager, why there were so many dorm rooms with untouched heating units. It was a summer thing and Bill never checked on their progress so none of it mattered but the job weighed on Dombal anyway. So, by mid-July, he was doing all the takedown and the cleanup while Murph slept.

But even on the level of a simple conversation, Murph would not just do the conversation. Dombal would say something, ask a question or make an observation or just anything, and Murph might respond, but what he said so rarely corresponded with the initial remark that Dombal often settled for silence. "What is that song?" Dombal had asked that morning when Murph put a tape in the tape deck of the Physical Plant van they used to haul the shop vac from dorm to dorm. "You don't get to know," Murph said and that was it, just a hot, whistling silence for the rest of the trip across campus. But it was hot by the 
dumpsters and Dombal couldn't resist saying, "It's hot," and Murph just looked on at the trash, eating his sandwich, the same way he would if there was no Dombal there at all.

"Look at that yeti," Murph said instead, gesturing with his sandwich at the Yeti, who was assembling a window-washing nozzle on the soccer field at the bottom of the hill. The Yeti's real name was Laura, but on the first day, when all the summer workers got put into teams, Murph had called her the Yeti and that was the end of the name Laura for her. She was the Yeti because she was an enormous person, just truly a walking marvel. Not in a fat way, though she was thick. It was more of a freakish dialing up of the proportions-hands larger than hands should be, a face broader and squarer than a face should rightfully be. Only her feet were sized for a normal person, and she wore white canvas slippers that brought her body to a sharp, precarious point.

"Yeah, heh," Dombal said, looking at the Yeti.

"I'm going to do something to that yeti," Murph said.

"Yeah?" The Yeti made Dombal sick in his gut. He watched her massive red hands assembling the window-washing apparatus and something low and spastic foamed in his heart, like his blood was ice-cold cola. There were people Dombal didn't like because of what they'd done to him and then there were people he didn't like just because of the postures they struck in the world, and the Yeti was in the latter group. Her very presence in a room stirred up a crazy rage.

"That yeti has something coming to it," Murph said.

"Yeah. Like what are you thinking?"

Murph forced the last of the sandwich into his mouth, making a sick hump of his cheek, and chewed.

Oki, the janitor at Massassoit House, let Dombal into the building at the start of his shift. She was an ancient, stooped woman with a silver bowl cut who seemed always to be knitting in front of a small black and white television while water slowly boiled on a hot plate in the Janitors' Lounge. Dombal liked Oki because she smiled at him and didn't ask him questions and didn't in her countenance make him feel guilty that his life still lay before him like bare parchment before the map is drawn while hers was, in almost every way, already done.

"You on third floor today?" she said.

"I think so."

Dombal shouldered his vacuum and his tool bag and took the elevator to 
the third floor. He found Murph in the first dorm room, already asleep. Dombal took the elevator to the fourth floor because removing the grilles from the heating units was a loud and messy process and he didn't want to wake Murph. He entered the room that faced the elevator. The walls were yellowed and smudged, lit by the twin slim windows that let out onto the empty quad. Squares of tape and corkboard riddled the surface of the walls, furred with loose drafts of carpet pile, human hair, stray ash. Dombal put his tool kit on the bare mattress and removed a screwdriver and a rubber mallet. The grille had been painted over several times-he could barely make out where the screws were. He centered the tool over the area where he guessed the center of the first screw head was and pounded with the mallet until he broke through and gained purchase. Sometimes this process damaged the grille, sometimes irreparably. But he was already doing another person's job and he wasn't happy about it, so if the grille broke it was not his fault.

Dombal drove out the screws one by one, leaning into the handle of the screwdriver with all his strength as he twisted. When he finished, his hands tingled as if being pelted with sparks. The blades of the heating unit were draped with a mat of gray dust. He sucked this away with the vacuum, exposing the delicate copper apparatus which was like the spine of a prehistoric snake. Something went into the vacuum that was not dust and the vacuum clogged. He looked into the nozzle of the vacuum and saw a lump of red fabric. He used the screwdriver to tease it back out. It was a woman's silk panty, red with orange stripes. He unfolded the underwear on the floor. It was still relatively clean. It must have fallen behind the heating unit only recently. Dombal picked the underwear up and held it in his palms. It seemed impossibly small. He thought about the person who wore the garment, and how she might have inhabited it, how much space she took up in the world. There was a dimensionality to bodies that didn't translate well from the photographs and illustrations he used for masturbation. He saw something move out of the corner of his eye and turned. It was his reflection in the floor-length mirror that was bolted to the dorm room's door. He saw himself kneeling on the floor, holding the underwear. He stuffed it underneath the mattress and continued to the next room.

At lunch Dombal went to the vending machine to get Million Dollar Bash, which was a plastic bag filled with nuts and dried fruit and chocolate drops. It was the only thing left in the vending machine, but this was no big deal because Dombal happened to like Million Dollar Bash. He usually found 
enough loose change in the heating units to buy one bag a day, which he ate silently on the bottom bunk in one of the empty dorm rooms, handful by handful. He put the change in the machine and pressed the buttons and the corkscrew that held the bags of Million Dollar Bash turned, moving them forward in graceful orchestration. As the corkscrew turned, Dombal saw Murph reflected in the vending machine's glass surface. He was sitting on a table in the lobby, talking to the Yeti. The frontmost bag of Million Dollar Bash dropped into the receptacle and Dombal reached through the spring-loaded door to retrieve it.

"This is just what Bill told me. All the mattresses, down to the lobby," the Yeti said as Dombal approached the table. She gave off a dense, yeasty smell.

"Down here, in the lobby." Dombal said.

"All of them."

Dombal looked at Murph, who just stared out the window at the abstract steel sculpture in the quad, baseball cap pulled down over his brow.

"Why?"

"They're getting replaced." The Yeti whipped a sash of her straight colorless hair over her shoulder and then stroked it as if to apologize. "We bring them down to the lobby and next week they bring dumpsters. Then later, the new ones come."

"What about the vents?"

"They said the vents can wait," the Yeti said. "The mattresses need to be down."

"Who said this? About the mattresses."

"I told you. This was Bill. Speaking directly to me."

"Bill? He came here?" Dombal had not seen Bill since the start of summer session, when he gave a brusque demo of the shop vac in a full universitythemed track suit. Dombal had stopped thinking about the Physical Plant staff altogether except as a sort of ghostly cabal, hovering invisibly and shapelessly above the dormitories.

"Let's get this over with," the Yeti said, clapping her hands together and rubbing them. Dombal and the Yeti started across the lobby but Murph continued to sit on the table.

"Come on," the Yeti said. Murph did not respond. "Are you seriously not going to help?" she said with a sense of naïve wonderment that seemed momentarily to shake Murph. He pulled at the brim of his cap and slid down off the table, deliberately looking away from Dombal and the Yeti as he approached. 
The mattresses were gray and slick, threadbare ellipses worried into their midsections, the mark of semester after semester of muted couplings and studied, repetitive groinwork. Faint impressions of menstrual spotting, Rorschach pissmarks. Dombal and the Yeti worked as a team, each taking hold of one end and scuttling down the halls like crabs. When they reached the stairwell they would hoist the mattresses over the guardrail and let them fall. Murph worked alone on the first floor, thrashing and pounding the mattresses down the hall.

After two hours they'd only managed to move nine out of two hundred and forty mattresses into the lobby. Murph spread out on one and shut his eyes.

"Lazy," the Yeti said. Murph opened one eye and then shut it again.

"Let's get the rest," Dombal said, heading toward the stairwell.

"Are you always this lazy?" the Yeti called out to Murph. He smacked his lips and rolled over onto his stomach. His basketball shorts came down a little when he moved so that his crack was showing, but it somehow looked okay.

The Yeti stood at the threshold of the foyer, waiting for Murph to respond. Dombal started to climb the stairs.

When Dombal got to Massassoit House the next morning the mattresses were rearranged. They had been stacked into a kind of fort. Six mattresses on their side and three draped on top. Dombal walked around the perimeter of the structure. It looked sturdy. It looked like someone had put some amount of time and effort into its construction. The mattresses were slightly parted on one side and Dombal leaned in to have a look but as he crouched at the opening he heard a sound. A rough, scattered breath, issued from high in the throat, choked off in mid-exhalation. Dombal rocked forward slowly, pressing his knuckles into the stiff carpet pile for balance. The breathing stopped. Dombal went rigid. He could actually feel the blood rushing through his ears, sloshing like a riptide. The breath was gone for a long time, and then it erupted again in earnest, rhythmic and fierce. He crawled silently toward the aperture, which glowed faintly from the inside. The breathing took on a raw whistling overtone. Dombal put his cheek against the wall of the cavity and peered in. He saw the thickset curve of the Yeti's right buttock, clutched in a percussive spasm against Murph's prone leg. Dombal knew it was Murph because of his green-striped athletic socks and blown-out Keds. Stretched impossibly across the Yeti's pinched behind, strapped there like a tourniquet, was the pair of red and orange underpants that Dombal had found behind the heating unit. The pair that he'd held in his hands. 
Dombal pivoted slowly and sat on his haunches to wait it out. There was nobody in the hall and nobody in the quad.

"Hey." It was Murph, calling from inside the hut when they were finally done with the thing. Dombal turned and saw Murph's naked arm extended through the opening. He held a five-dollar bill between his index and middle fingers. "Go get two Cokes and a Million Dollar Bash."

Dombal took the bill and walked down the hallway to the recessed vending area. He made change for the five. Coins spilled into the tarnished metal dish. Dombal scooped up the coins and approached the machine that had Million Dollar Bash. He saw his reflection in the glass. There was more flesh on his head than he remembered or wished to remember. He put the coins in the machine and pressed the keys and the corkscrew turned, moving the cellophane bags along the track.

"You made a nice house," Oki said, looking away from Dombal so that he knew she did not think it was a nice house at all. She was frying something on the hot plate, a sort of egg with red sauce.

Dombal took his tool bag from the utility closet. "I didn't have anything to do with it."

"Bill came here. He didn't like it."

"Bill?"

"Bill. The manager."

"What did he say?"

"He say he didn't like it. You need to take it down."

Oki looked up at Dombal. Her face was old and theatrical. She went back to her task, batting the pale mashed egg around in the saucepan. Dombal looked in his tool bag to make sure everything was there. He closed the bag and took the elevator up to the first-floor lobby.

There were more mattresses, maybe seventy-five of them, piled high in the space in an intricate pattern. The structure had the feel of a Sumerian ziggurat, its peak grazing the acoustic tile of the drop ceiling. It seemed to have at least two levels, the higher of which could be accessed by a graded staircase made from mattresses that were stacked and staggered with an architect's precision. The structure had a look of real permanence, as though it had been built thousands of years in the past.

Dombal just stood and looked at the structure for a long time. His heart was beating so fast that he almost fainted. He wanted to jump up and give a flying roundhouse kick to one of the towers. He waited to hear a sound but there 
was nothing. He moved closer to the staircase. There wasn't any person or any sound. He put his foot on the first step.

"Hey." It was Murph's voice. Dombal looked down the hall. Murph was struggling with a mattress that had doubled over on the landing of the central stairs. "A little help?"

Dombal put down the tool bag and walked over to Murph.

"Fuckwad."

"What?"

"Fuckwad. What I said."

Dombal grasped the white twine handles sewn to the sides of the mattress and the two of them lifted it just high enough so that it grazed the surface of the rug.

"Where's that Yeti?" Dombal said as they scuttled down the hallway toward the temple.

Murph looked up and nodded toward the entrance.

"I didn't hear anything," Dombal said.

"I'll show you." They got to the temple and Murph dropped his end. He climbed the stairs and, halfway up, made a little sweeping gesture with his hand that meant Dombal was to follow him. They went in and padded down a dark corridor. At the end of the corridor there was a small open space. The Yeti lay inside, on her side, unconscious, wearing only an enormous pair of emerald, silken underpants and a white cotton bra. Her feet were bound at the ankle. In the opposite corner of the room there was a heap of empty candy wrappers, crushed Million Dollar Bash bags, Coke bottles, a half-eaten bag of carrots, a jar of mayonnaise, and a shallow bowl of water.

"What is this?" Dombal wanted to back out of the room but the moment to do so came and went and he was still standing there, looking down at the Yeti sleeping on the stained mattress, all tied up.

"You asked where she was." Murph knelt behind the Yeti and put his hand on her thigh.

"Is she okay?"

"She sleeps in."

"You-you sleep here?"

"I've been. Yeah."

The Yeti breathed evenly in her sleep. There was no other sound in the small room.

"I don't-what's happening?"

Murph stood up. "Just help me carry some more mattresses." 
"She's okay, though."

"Yes, fuckwad. This is what she wanted. She asked for this." He slid past Dombal and disappeared down the corridor. "Come the fuck on, twat," he called out over his shoulder.

Dombal looked at the Yeti. Her breasts pooled unevenly in the massive brassiere. Her mouth was slightly open. He wanted to kick her in the gut.

They went up the stairs to the top floor. Murph had yanked all of the remaining mattresses out into the hallway, where they lay slumped like victims of a gas attack. Without speaking they lifted the mattresses by their handles and hauled them to the stairwell.

"Why are you doing this?" Dombal asked.

"I'm bored."

"You spend all day with that Yeti."

"I guess I'm really giving it to her," he said, and it was the first time he had ever agreed with something Dombal had said. He grinned in the dry aftermath of the sentence like a fox with a quail in its mouth.

"It doesn't seem like you are," Dombal said in a wispy voice.

"Huh."

"You're just spending all your time with the Yeti. Like, sleeping with the Yeti, the whole day."

"What's your point, twatstick?" Murph dropped his end of the mattress. It sagged on the landing.

Dombal's every muscle was taut. He wasn't able to say anything. Time slipped by like the particles of dust briefly illuminated by the tall windows flanking the stairwell.

"What is your point?"

Dombal dropped his end of the mattress and walked down the corridor. Halfway down, he realized that the only other way off the top floor was the fire exit, so he turned into one of the empty dorm rooms and sat on the steel frame of one of the beds. The springs grated and snapped under his weight. Someone had scratched an impossibly long penis into the brown paint along the length of the frame. Dombal stared at the illustration and waited for Murph to come in and start whaling on him, but he couldn't hear anything but the sprinklers jetting rhythmically over the lacrosse field. He waited for what seemed like a really long time for Murph's fist to find his head or his chest or wherever Murph saw fit to whack him but Murph did not appear. Dombal's face tingled with the anticipation of the blow. He lay back on the frame and the springs 
dug into the base of his skull, trapping tufts of his hair in their tight coils, and he stiffened out and waited in the room for as long as he could stand to.

The next morning Dombal went to the Physical Plant building. Bill's office assistant let him in and told him to sit in the narrow, walled-in waiting area. She took a phone call while he paged through a weekly magazine, reading nothing of its contents, his tacky fingers warping the paper.

The assistant placed the receiver in its cradle and called Dombal into Bill's office, which was an arid, cream-colored room without windows. Vendor calendars hung on the far wall, grimly designed documents top-heavy with photographs of women in puffed hair breaking up concrete with slick jackhammers. Bill sat behind a steel desk and listened without blinking as Dombal told him about the mattresses and what went on inside. Bill's face lacked dimensionality. It was as if all of his features were spread out on a single plane like a Mercator map. He sat in his chair and took in Dombal's report with the focused earnestness of a deacon.

"Is that all you can think of?" Bill asked when Dombal stopped talking. "Anything else you want to tell me?"

"I want a cordless screwdriver," Dombal said in a thin, crackling voice.

"Pardon?"

"My hands hurt from taking apart all those heating units. I am awake half the night in pain. I want a cordless screwdriver."

"Why don't you take the rest of the day off?"

Dombal got up and walked out of the Physical Plant building. He flinched in the sunlight, expecting to see Murph in the quad, running swiftly toward him with a bat. But there was just the piping heat radiating from the blacktop. He took the long way around campus but even so he saw the ambulance careen through the narrow paths that led to the dormitory block, escorted by two squad cars. His gut steamed, so he took the dirt path up the hill to the convenience store and bought a large ice beverage and sat at the lone table by the window to drink it. The spoon for the beverage doubled as a straw. He pressed his left fist into his right palm to stanch the dull roaring ache. He had the striped underpants balled up in his pants pocket but he didn't know yet what he would do with them. A customer entered the convenience store and bought a snack stick. Dombal spooned up a heap of the ice beverage and held it against the roof of his mouth until the customer left. The day would be stupid and hard, and would take the endurance of a mountain climber just to endure. 


\section{How the Rebels Took Port Harcourt}

I do not remember when or how I ended up traveling on all fours. I was wandering through the delta in tattered fatigues, far from my battalion, which was not so much of a battalion since it had been torn apart by mortar fire outside Warri. I had no more water in my canteen and only a half-eaten meal bar (fruit medley) in my shirt pocket. My son, an electronic surrogate for the real one that died in its mother's womb, was shattered in pieces inside a blue gym bag strapped to my back. I had been awake for something close to seventy hours. My headspace churned, fluid with hallucination. I suffered visions of colossal snakes descending upon me from the dense canopy, their jaws distended, absorbing my head down their throats like a hand into a black leather glove. I am certain I was bitten by a fat violet spider at one point, whose venom worked on me like a whole bottleful of the malaria medication I had not taken for days, the kind that made you paranoid. I saw dead rebels in rotting black flak jackets rise up from the swampy bogs, their greenish flesh flaking loose from the skull. They shadowed me in the dappled half-light, slinking effortlessly through the peat. These visions gave way to a period of darkness in my mind, and after that I was crawling on a dirt road-nothing more, really, than two soft tracks worried into the trashed, primal wilderness. I crept along the roadside for as long as I could stand it before collapsing in a shallow, grassy ditch.

I blacked out and when I came back the sun was different. Higher, with a greenish halo. I heard a churning sound, like wood in a chipper. I arched back and saw a beaten blue taxi coming straight for me. I was convinced it was part of the rebel faction that had shredded my comrades at the derricks. I rolled out into the middle of the road and waited for the taxi to run me down. But instead it slowed and stopped, and the cab driver-a spindly man with a white scouring pad for a beard-emerged from behind the wheel, hefted me by the underarms, and tossed me in the back seat. I'd slept on my arm and it fizzed with a dull, tender chill as it came back to life. I sat up straight. It was noonish. The sun moved along in the sky at high bake. We were speeding through a lush 
nowherescape, gnarled trees sprouting lonesome amidst stiff yellow grasses. The driver had the radio up unseasonably loud. Some young tough grousing in staccato pidgin.

"What is this?" I called up to the front, startling the driver.

"Why should it matter?" he called back without a pause.

"Can't argue with that," I said, and leaned back against the window, making the most of a lukewarm breeze that was threatening to cool my neck. I stretched my legs out across the seat and rolled up the pant legs. My calves were gouged and dented in places I wasn't aware I'd damaged. I thought about the men in my battalion. I wondered how many were left.

The song faded in an extended chorus, replaced by an angry man's voice, calling out to the people of the delta to rise up, rise up against. Then another song, not entirely distinguishable from the last.

"Where we headed?" I asked.

"Away from Port Harcourt."

I nodded. I had, in the past twenty-four hours, seen two good friends roasted alive by a jury-rigged flame thrower. A third got flipped in the air by a roadside bomb, which carved out half his face. I was not anxious for more of it. The rebels could take the whole country for all I cared. I wanted only to get back to cool, cavernous America where my son could be reassembled.

He drove for a while, running his tongue across his taut, purplish lips. As if he might be daring himself to ask me something. "What is your story?" he said finally, gesturing at my outfit. "You military man."

"Oh, this," I said. "It's not-I'm not with the army."

The driver raised his eyebrows.

"I'm a contractor. For Shelton."

"Oil man."

"I actually couldn't give one what Shelton makes. I'm pulling down sixty an hour with O.T. Or I was."

"You are from America, though."

I nodded. I did not even want to be talking! I was in Nigeria on a security contract-it was cheaper and easier for the oil companies to hire American paramilitary outfits for security detail on their facilities than to try to get people in-country, on account of no one wanted to be a target for the rebels or betray their nation, whereas we were sharp and hungry to take on all comers. Until the rebels came in the night and routed us without hardly breaking a sweat. I told the driver none of this.

We continued on in silence for a long stretch, moving very slowly through 
a rained-out gully choked with reeds. In the distance a gas flare sent stippled gray plumes into the air.

"I thought America would have fixed this by now," the driver said.

"Excuse?"

"This, what is happening here. The rebels and the government. The insurgency. I thought of Americans coming here to end the fighting."

"I'm not a politician, so I don't know thing one about what's happening," I said, hoping that would suffice. I could guess why America wasn't coming to Nigeria's aid (mainly that it was a shit country), but I was not inclined to engage the man. I just wanted to gain purchase on a tract of land with usable buildings and roads. A place that looked remotely like it might have an Internet connection. Or at least Skittles.

"Where are we headed, anyway, if not Port Harcourt?"

"I am going to my brother's house."

"Your brother."

"He has a farm. I am going to stay with him." The driver paused, glancing at the digital clock on the dashboard. "You can stay with us if you like."

I muttered something.

He kept driving for a long time, not saying or doing much of anything. I watched his eyes through the rear view mirror. They never left the road. A rebel's eyes would have drifted. His lids were puffed, as if brimming with tears, although his face was calm and elastic.

The gully gave way to a sort of low, dusty land broken up by low-growing trees and brush the likes of which I'd never seen before. I untied the gym bag containing my son and unzipped it in my lap. The speaker had come loose from its binding in travel, and a rat's nest of wires hung from the casing. I gently forced the wires back into his frame and tried to tighten the fabric. Jerome-that's the name of the boy-was a peanut-shaped thing, approximately the size of a loaf of bread, "designed to forestall grief in mothers who have miscarried." That was the description of the boy in the brochure given to Mandy and me by our health care professional in our absolute darkest writhing hour. The peanut had a voicebox, and the longer you held it, the more things it said. The doctors gave Jerome to Mandy just hours after the miscarriage, within the bonding window, as they referred to it. We sat in the recovery room and looked at the thing sitting there in its bassinet. Then it made a tiny whirring sound, a sad sort of digital sigh, and I went and picked it up and the whirring stopped. I held it for a while and then Mandy asked for it. She took it in her arms and she grimaced and held it tightly and before long it was no 
longer an "it" but Jerome, and we took him home with us. Then things started to heat up in the delta and I was called into duty, and not six weeks later I got a big Jerome-shaped box in the mail along with a scented letter from Mandy explaining that she couldn't take care of him properly while also attending nursing school and maintaining her spot in the leaderboards on Dance Dance Execution, which was in the high tens, which meant that she was competing with actual Koreans who ruled that game. I saw this as a real sign, that the boy was being sent down a vast river to me by his mother, just like Moses down the Nile if Moses' mother was a wicked, selfish philanderer (I only half-remember the tale). It was the one real sign I have ever gotten, and I have contracted in most of the holy lands and elsewhere in many sacred and mystic places where you would expect to receive signs. I resolved to give Jerome my all, but I fumbled. One night the rebels made it through the concrete barriers and torched us with Molotovs. I was only half-awake when a guy came at me with a two-byfour wrapped in concertina and smashed me in the lower back, which is where I kept Jerome. Because of me, because of my ineptitude and torpor, Jerome was junk. He was just a heap of parts in a bag.

"Son," I whispered. I looked up to see whether the driver was looking back, but his watery, placid eyes remained focused on the road. "Son, I just want to know-are you still in there? Is there some compartment in there, something built in, an escape hatch of some kind into which you could leap in case of a rocket attack or something? Did your builders build that?"

His pieces sat silently in my lap, his speaker cone trembling with the pits in the road.

The radio cut out in a sharp blister of static. The dashboard lights went brown. "I wish that this wasn't happening," the driver said. He pointed to the gas meter, the needle of which dipped at irregular intervals below the "empty" hashmark.

"No gas," I said.

"No gas," he said. "When things go bad, my brother says, 'No gas in the oil fields.' And now we have no gas in the oil fields. So you know how bad things get when things go bad." He pulled over to the side of the road.

"What are you doing?" I asked.

"We need to wait here. Someone will come by."

"They'll just give us gas?"

"Most likely we will have to take it from them," he said, and reached under the passenger seat to retrieve an AK-47.

"Whoa," I said, ducking involuntarily. "Where do you get a thing like that?" 
It was in beautiful shape, its rosewood butt warm and polished like the skin of a Christmas chestnut.

"The Russians were not stingy when it came to spreading the word of communism," he said, his mouth for the first time sporting a sort of diluted grin, chased with self-satisfaction. "Anyone with a cause, they provided the weapons."

"All due respect, your people are communists?"

"No, not here. But during the civil war they gave out guns to anyone who might have a reason to overthrow the government."

"That's slick," I said, shaking my head. "All that stuff you hear about conspiracies, secret documents, things getting shipped here and there. Very slick."

"Not very slick," the driver said, running an oily hand towel slowly over the barrel of the rifle. "The Soviets are gone. They went the way of the dinosaurs, nothing left but the fossils rusting away in their missile silos. The Americans, that is what is slick. You see an opportunity to bring hamburgers and soft drinks to a country, you do it out in the open, shaking hands with everybody, smiling. Whenever you open a new restaurant chain, a local band plays and the children are given small toys in vacuum-sealed bags. It has become a cause for celebration."

"You're talking about Arby's, now."

"The Soviets failed to change the world because they misunderstood how it worked. The Americans understand, and that is how you will spread your arms so wide. When you shake hands, your hands shake the world."

"What side are you on?"

"What?"

"Is this," I said, and then stopped to clear a gob of something in my throat. "Are you going to shoot me, or."

The driver released the trunk and got out of the cab. I sat with Jerome in my lap while he rummaged around with one arm, the other arm cradling the rifle. There was the sound of him unzipping a suitcase, and then a more muted rustling. He closed the trunk with the careful, assured motion of a man who had cared for his vehicle for decades. He came up to the rear passenger side door and peered in, handing me a kind of dried meat wrapped in cellophane and a handgun.

"That's more like it," I said.

"What is that?" he asked, pointing the AK barrel at Jerome's body.

"That's my son," I said, and I could not entirely disguise the bitter defiance that accompanied my response. 
The driver made a sort of shrugging gesture and placed his free hand on the door. "Get out. You will get in the driver's seat. Do you understand? You will sit there and wait for someone to come by. I will be up in the trees-"

"Up in the trees?"

"Yes," he said, somewhat irritated, "up there, in those trees, with the rifle. I will be watching from there. You will wave down the passing vehicle. You will beg them for gas. If they give it to you, you thank them and give them the meat. If they do not give it to you, you tell them there is a man in the trees with a rifle. They will give you some gas."

"What if they don't?"

"Most people, when they hear there is a man in the trees with a gun, will give you the gas without an argument."

"What if they don't?"

"That is why you have the gun."

"You want me to hold them up?"

"Very few people would put up a struggle at that point, just over gas."

"I don't even get to eat the meat?"

"If you don't have dash, people will be very upset. It's better to give them the meat."

He walked slowly toward the tree line, the brush engulfing him by degrees until it swallowed him altogether. I reluctantly got out of the car and walked around to the driver's seat.

"Man," I said to Jerome. "This is rich. I wish you could see this, son. Your father has gotten himself into one hell of a situation here. I never would have thought of this as the ending of my life, son. Not in a million years. I always thought of myself dying at home, in a recliner, fading out to the voice of a well-groomed game show announcer, just gently croaking in an air-conditioned room. I never would have guessed I'd be here, sitting in a foreign taxi cab, misty with sweat, a hunk of meat in my lap, just waiting to get gunned down."

The afternoon crawled. I fought off all manner of wispy, needle-nosed bugs that swarmed my personal space. I held in my lap my broken son and a loaf of aromatic meat wrapped in plastic. The shadows of the trees crept along the road, engulfing it. In the distance, the sound of a motor heaved forward through the brush. A reflective shaft of silver light pierced the horizon where the road rose up and disappeared. I put Jerome on the floor of the passenger side and lay the meat out in the bucket seat so that whoever was coming would have a clear view. The vehicle was a burgundy station wagon with the back 
windows obscured by sheets of corrugated steel. I counted three men in the car. As it came closer, I saw that the men were wearing the signature black kerchiefs over their mouths and noses. They pulled up alongside the cab.

"Soldier man. You are broken down?" the driver asked, the kerchief puffing out from his face like a tiny lung.

"I need gas. I just need gas. You have gas?"

"No," the driver said in a low voice. "I don't have gas. Do you have gas?"

I did not know what to say to that. I felt that I had already answered that question. A tear of sweat ran in a ragged swath down along the crease of my eyelid, its salt burning my eyes, but I willed myself into stillness.

"I don't have gas," I said, in the end. "That's why I was asking. Do you have gas?"

The driver looked back at one of the passengers, who began to work at something I could not see in the back seat.

"Maybe you don't understand," I said. "I'm not trying to do anything here. Just get some gas, get to the next gas station. Maybe some-"

I let the phrase trail off into the hazy distance between us. The man in the driver's seat regarded me with furious restraint. His eyeballs were a capillary relief map, practically furry with raised, reddened blood vessels.

"We can get you gas," he said. "But we need some things too. Maybe you have some of the things we need."

"Okay," I said, patting the loaf in the passenger seat. "You want this."

The driver, without glancing at the loaf, said, "We would like you to exit the cab."

I had a gun hidden at the small of my back. I had years of military training. I had seen people die. I had killed the people I saw die. There was a lady in the United States whose unscrupulous body knew mine. These were the things I thought then, clearly ordered and prioritized in my mind.

"Okay. I'll get out. I should just tell you guys, though, that there is a guy in the trees with a gun."

The driver's eyes briefly fluttered, scanning the canopy. The passenger shouldered an automatic rifle and aimed at me. I dove for the floor as a bouquet of glass shards bloomed in the cab's airspace. I heard the men shouting as the $\mathrm{cab}$ driver returned fire. The station wagon peeled out, fishtailing into the cab, which sent me ass over end into the passenger seat, a shower of glass cascading over me in a great wave. I heard one of the station wagon's wheels rupture, sending the hubcap spinning off into the brush. There followed a round of 
spastic shouting, and then a short burst of rifle fire, and then there was just the sound of the station wagon idling and a weird insect buzzing in the trees.

"It's okay," I heard the cab driver shout from high up. "It's okay. They're gone."

I righted myself, shaking the glass shards from my clothes. In the rear view mirror I could see a column of smoke rising from the shoulder of the road. I turned to see the station wagon sloped into a ditch, a burled cloud streaming from the hood. An inverted body dangled from the passenger side window, the arm chewed up and gristly.

The door to the cab was not working, so I climbed out through the open window. My calves pulsed, my whole lower half a complex lacework of gashes.

The driver scurried down the tree trunk. "Quickly," he shouted breathlessly, "the siphon, the siphon."

He pointed dramatically at the trunk of the cab as he descended.

"No, no way," I shouted. "That wagon's about to blow. Neither of us are going near that thing."

"The siphon," he said with greater intensity, as if to drown out my response.

"Man, I am not getting the siphon. That's outrageous."

"Get the siphon. The siphon," he kept repeating. He was almost at ground level, breathless, so that the shout was more like a hollow whistle. I just heard the whiny upper registers. It was sort of musical.

I figured the old man was going to end up getting the siphon himself anyway, and to stand there motionless while he fished around in the trunk would only humiliate him. He had, too, just skillfully taken out three marauders from a treetop. So I reached down for the trunk release and popped the lever as he rushed over, tossing the rifle over his shoulder.

"You are an American pussy," he said, pushing past me to retrieve the siphon. I could have come up with some sound arguments against the claim, but this was, I knew, not the time for it.

He rushed over to the station wagon with a length of greasy plastic tubing and a five-gallon metal tank and set to work. He swiftly unscrewed the gas cap and threaded the pipe into the hole. In one fluid motion he sucked the gas up through the tube, drew it from his lips, capped it with a thumb, and forced it down the narrow throat of the gas can. The car was smoking like a tycoon, big black roiling smoke pouring from the hood, but the cab driver leaned back casually, hands thrust in his pockets, rocking back on his heels, as though he were waiting for an ice cream sundae.

When the tank was full he withdrew the siphon and jogged over to the cab 
where he began the process in reverse, again with the assured motion of a professional. While the tank was filling, he bent to glance inside the cab.

"This shouldn't have happened," he said, gesturing hastily at the shattered windshield. "Who will pick this up, this mess you've made?"

I set my jaw and returned to the cab, where I began picking out the glass shards and tossing them into the high grass. "Diamonds of Sierra Leone," I said under my breath. The driver did not respond, only tightened the gas cap, closed the hatch, and started up the cab.

"Get in," he said. "We go to my brother's now."

I sat down and went to buckle myself in, but there was no belt, so I shifted around in the seat, the remaining shards grinding against my boots.

We drove for a long time on the siphoned gas. I had to allow a grudging respect for the man, who was nothing if not resourceful. We drove through a dull, shiftless landscape until the sky turned a heinous orange, the undersides of the pulled-apart clouds going deep and bloody.

"Man, I am sorry about your cab."

"It's not mine."

"It must be like pulverized."

"It's a company car. I can't even put a bumper sticker on it."

"Just shot through and through. A total disaster."

The driver waved off my comments, hissing through pursed lips.

It got dark, and we had no working headlights, so we slowed down to a crawl. The road was caked in litter. The wheels of the cab crushed each soda can, plastic chips wrapper, and desiccated meal with protracted relish. I leaned forward, my elbows resting on the dash, staring through the gaping hole where the windshield had once been to check the road for any beasts that may have wandered into our path.

"You mentioned a civil war?" I asked. I had not slept a real sleep in days (days!), and the dearth of sensory stimuli was wearing on my level of alertness. I felt like I was speaking through a tank of heavy water-each word floated up in a private orb, undulating independently of its peers. I just watched them rise, praying that they'd make sense when they reached the winged men and women who populated the heavens.

"Biafra."

Before they shipped us over, our employer, Evergreen Security Solutions, put us through a rather thorough training course. I remembered a PowerPoint presentation on Biafra. I remembered how the rebels in that war had made their own tanks from sheet metal and old cars. Badass. "You were part of that?" 
"I was a teacher."

"No shit."

"Many years ago, things were better here. I was a teacher. I had a wife and two boys."

"And then the, what, the military, or-"

"We had, in Nigeria, a very stable government when I was growing up. Each year, it seemed that things were getting better. We were on the elevator to the first world. And then suddenly the oil companies came and everything just went sideways. A long time, the country went sideways. Biafra was an attempt to stand straight again, but it failed. We failed. And so things continued to slip down. And now this."

"I do not know how a thing like that happens," I said. "I just don't."

The driver made a little brushing motion with his hand, and I had a hard time understanding it for what it was. But I figured, any way you cut it, he was not up for an extended conversation about his ruined past. So I put my head back against the headrest and watched the cool gray procession of midnight forest unfolding before us.

"That bag," the driver said, tilting his head toward my lap.

"My son?"

He raised his hands over the steering wheel to emphasize his lack of comprehension.

"Well," I said, sucking my teeth, "he started out as just a tool. My Mandy, she had a miscarriage? And the doctors gave her Jerome-my son-as a way to sort of get over it or live through it or what have you? And I just, I have to get him back to the US and get him put together again. Or something."

The driver nodded and we drove on. I assumed he regarded me as the supreme jackass, a living incarnation of all he'd secretly assumed about the rolling American nightmare. A grown man playing soldier, carrying around a trussed-up radio and calling it a boy. I suppose he had a sort of point. But something happens to a person when a small and needy object is placed in his arms. Something slips away from you, a taut and slithery thing that might be reason, and once it's gone, you have only the foaming, bared teeth of parenthood, a wild, insensate desire to wall up your private airspace and gun down all foes.

The driver smacked his lips.

"You thirsty?"

"I have lost my children," the driver said. His nostrils were quivering faintly, 
but otherwise he was still as a piece of museum statuary. "There is no bringing them back."

"Yeah," I said. "I think I have some water here. Or maybe it's bourbon." I started to rummage for the bourbon. My hands trembled, I wanted to get it out so fast.

"I was not at home when they were killed. I was at the school. They came into the school first and told us to get down. We all got down. I thought about it for a long time. Could I have just refused to get down? Could I have made it out through the window? It was something I thought about a lot, maybe too much. At any rate, while we were on the floor, they were burning the houses. And my wife and my children were in the houses, burning, while I lay on the floor. And I remember that my face was pressed to the floor and it was concrete and I thought about how cool it was, and I think it was in that moment of relief, in that moment when I thanked the floor for being nice and cool, that is the very same moment that my wife and my children left the earth. I wanted so much to go back, to try the window, to try to run for the door, to fight the soldiers, to run back to the house and warn my family, but in my mind I could never make it back in time. So I have given it up. Now I carry it around with me. I balance it on my head like a woman carrying water."

The man's eyes were glazed and slick. His speech was slurred, almost as if he were drunk with the remembered pain.

"I think that I don't actually have the bourbon," I said. "I think I may have just been hoping for the bourbon."

He looked at me, puzzled, as though I'd shaken him from a fitful sleep.

"I offered you bourbon," I said. "Never mind. I don't have it. I don't have anything in this bag, just nothing."

"Mm-hm," he said, returning his gaze to the road.

I was at the base conducting a session on the M60 when the call came through. Mandy sounded rough, like she had inhaled paint fumes or something. Her voice was syrupy and slurred. She told me the baby was having problems. She was calling from an ambulance. It was hard for her to talk, she said, because they had an oxygen mask over her face. I said okay and I told her to just keep the phone by her ear. I told her not to think about the baby. She said "How" and I said I would talk to her about when we met. She said that sounded good so I told her everything I remembered. I was on a detail in Honduras and she was working as a missionary. I described to her the ruins we discovered on our walks together, those mighty caved-in pyramids that were just there in the 
middle of the jungle, no velvet ropes around them or anything. I told her about the time we climbed the ancient stairwell that wound around the side of the mountain, and when we got to the top the trees fell away and we were above a cloud of mist, and we were the only people there. I told her about the ex-pat bar in the middle of town, the Thursday-night karaoke with DJ Big Bill, how we sang a duet of "Magic Man" by Heart even though it was not a duet. I told her about the plantains, the salted, fried plantains, nothing like them anywhere ever in the entirety of the universe.

I got in the Impala and drove. When I got to the hospital they told me that the ambulance had arrived with the baby dead already. Dead inside her. Mandy said they made her go through labor anyway. They made her push that dead baby out. She said they set the lights low, and that it hurt worse than anything, because there was not a single fabric of hope to pull her through the pain, and I told her I was not prepared to hear the rest. She got upset, because she had no choice in the matter so why should I, and she tried to shout some more of the details to me while I begged her to stop. I think I heard that they cleaned the dead baby up and took a picture of him, and that this picture is still on file at the hospital, or something.

The dark was really starting to penetrate the landscape, its black cloak unraveling over the horizon. I stuck my head out the window to get a better look at the sky. The clouds were thick and variegated, black with smog. Portions of them lit up at spastic intervals. White streaks plowed through the sky around them like falling stars in reverse. Closer to the horizon, I could see a point where the clouds met the ground. Something was burning up ahead.

"Those clouds are not clouds."

"I know," he said, nodding evenly. "That is Port Harcourt."

"I thought we were heading away from Port Harcourt."

"I told you we had to take a detour."

"No, you did not."

"Oh," the driver said. "Maybe that was just a thing in my head.

"Why are we going back?"

"To get more gas. We are almost out again. I know a place, but we will skirt the city's edge."

The plan was sketchy, but I had seen the man conduct a treetop assassination. I was relatively sure he had my back. I settled into my seat, reaching for the AK. "I don't think this has many more rounds left in it," I said, thumbing the magazine. 
"The glove box," he said, gesturing at the smeary leatherette contour of the compartment. I turned the clasp and the whole door came away in my hand, allowing a half-dozen full magazines to slide out and tumble to the floor.

"You are not a man of chance," I said, stuffing two in my hip pockets.

"I'm not understanding," he said.

"You like to drive prepared."

He looked at me with that same expression of total puzzlement. I took it to mean that preparedness was a reflex in this place-that there was no state of unpreparedness, there were only degrees to which one was prepared for absolutely anything.

We kept driving along the single, weatherworn dirt road, never getting any closer to the source of the smoke. We started passing houses, the windows of which were mostly dark.

"They are trying not to be seen," the driver said, pointing at the squat gray structures, their facades blank and blurred with night air.

The back of my neck started to chill, and I felt a certain action in my bowels, a new level of engagement. We moved forward even more slowly than before. I placed the weapon crosswise on my lap and hugged the bag containing Jerome between my feet. We were night men, prowling silently through the living graveyard of houses and shabby storefronts festooned with banners of the new republic. A single boy wandered aimlessly in a field. There were no other signs of life.

"Where is everybody?" I asked.

The driver shrugged.

We were starting to see better in the dark. The landscape came up in sharp relief, everything clean and well-defined in shades of gray-blue. This was true darkness we were cutting through, almost by intuition or by some kind of oddball faith, just pulling ourselves along by an invisible thread. We were edging closer to the death zone-our ears rang with the surging chemical ductwork that accompanied the end time. I felt like I could split a man's teeth from five hundred yards with a single shot, blindfolded.

We entered a space that was more clearly identifiable as urban. The houses were coming together, rising into complexes, the stores becoming markets and other places of business. Lights out, everywhere. Some of these, we could see, had smashed windows. Whether or not this was evidence of the current aggression, we couldn't know. Everything was dead in the windless land.

"Damn, how far do we have to go into this?" I asked in a hushed, drymouthed whisper. 
"To the connector. Just a few miles," he said, wheezing, the first betrayal that he was not entirely confident about his plan.

"We don't have to," I said. "There's no law."

"Can't go back, can't stop," he said. I turned to look at where we'd been-a dark blue field framed by a dark blue sky, bands of deep purple fading at the horizon line, periodically ruptured by luminous tracer fire.

We turned onto a paved road and a new quiet blossomed over us in a meditative dome.

"We must be close," I said.

"This is a new road."

"The connector. We just pick up the connector. Get the hell out of here."

"I think we are not that close."

The road was marked with faint lane indicators, snaking, ghostly lines that undulated gently as they passed underneath the cab.

I turned, peeling my shirt from the seatback, where it had been adhered by a perspirative gel. "Do you think I'm crazy for carrying around this bag?"

The driver glanced furtively at the bag between my feet.

"I mean, does that make you lose a form of respect for me?"

"I don't know much about respect," he said, wiping a constellate of sweat from his forehead. "There are just actions. There is nothing else."

"But here I am, traipsing around your country with this bag of parts that I call 'Son."”

The driver squinted at something far away, his glistening eyes narrowing to slits. "What you carry, and what you call it, has no bearing for me."

As he said this, the driver sucked in his cheeks and lunged forward, slamming his foot on the brakes. I hurtled into the glove box, smashing my face on the dash.

"Jesus." My teeth were bleeding.

"This is bad," the driver said in a measured hush. In front of us, blocking a good portion of the road, was an overturned personnel carrier, just an enormous gray hulking thing, wrecked parts strewn everywhere.

"Whose is it?"

"Hard to tell these things anymore," he said. He took the AK and slipped out silently, crouching by the door. The world was dead quiet.

"Can't we just go around?"

"This is a trap," he whispered, waving bitterly in the air to silence me. "An old trick."

The driver pivoted expertly on the balls of his feet, his whole body a well- 
orchestrated mechanism for stealth. I could barely see him against the night as he silently maneuvered toward the front of the upended vehicle and ducked around the other side.

The night sounds howled in my ears as I tried to locate the driver's footfalls. Some kind of beast, something with long, sawing lungs, keened in the trees. I stared hard at the outline of the vehicle, which trembled and flagged in the near-total darkness.

I thought to call out to the driver, but I did not know his name. I realized I knew nothing about where I was or how I might get somewhere else. I knew not how to reassemble my son from the bag of parts at my feet. Nothing of the facts and figures I had stored up in my head over the years was applicable or transferable to this place. Like a campsite after a boy scout jamboree, Nigeria would be cleaner when I left than when I arrived.

A crispy insect spazzed in the crook of my neck. Twigs snapped. I slowly took the handgun from the small of my back, where it had made a deep and intricate impression. I cocked it in my lap with a long, deliberate stroke. 


\section{Heightmap of Her Countenance}

"Taff, check this out, doll." Breach was back from a scavenge run with a new piz inhaler. It was in the shape of a JK46 assault rifle. Burled wood butt, laser sight, platinum inlay. Everything to scale. Laid out on a bath towel on the couch. "Someone threw this in the trash. Looks brand-new!"

"You what-put that in your mouth?"

"What I heard is it gets you crazy ballistic."

He held it up and pointed it at me. "Go on. You get the first trace." I appreciated the generosity, but it was harder than I thought to put the business end of the thing in my mouth. Breach held it real still and gave me a hopeful look that put me at ease a little.

"Okay, you ready?"

"I suppose," even though I didn't suppose because I feared what this device was going to do to me.

"When I pull this trigger you're going to get pretty much knocked the fuck out."

"Okay."

"That's why the couch."

"Don't let me fall into the coffee table."

"I won't, Taff."

"Because the glass."

"Yup yup. You're a hundred percent."

I looked at Breach and tried hard to remember him as the young man I'd first met at the crash rally all those years ago, back when cars were still a thing people drove around in and crashed. I had this shady little memory of him offering me a spot in the slush line. He had wild eyes and just a confidence that made you want to curl yourself up inside him and be safe. You could hardly see any of that man anymore. That man I knew. He was just bits of flesh stretched over a polybase framework. A real brain bobbing inside a fake saline slurry. One leg still intact. A few original teeth. It wasn't him, but it was. But it also wasn't. I couldn't tell where he ended and where my vision of him began, and because 
of that I wanted only to be high, all the time, until we both died, whenever these bods would finally give out.

I am reasonably certain he felt the same about me.

He pulled the trigger and I fell backwards into a cosmic trench, tumbling through the gritty haze for what felt like scores of lifetimes all strung together with light and needles. My spine pulsed like a rabbit heart. I was one hundred and fifty-two years old, but I felt much older, like a wise alien with mantis eyes. I felt I could predict the weather by palming the textured air. I opened my mouth and there was a symphony spraying in red jets from my gums. I was a close-up of a popsicle melting over a sleeping mink. I bit down on time's rubbered teat and dangled there until everything went cool gray and fizzed.

I woke up on the floor underneath the coffee table in a warm pool of my own fluids. Breach was making fake waffles in the petakiln. I groaned and he looked over.

"Wicking pad's on the couch," he said. I draped the pad over my body and let it do its thing. It felt like a thousand octopi were crawling all over me.

"How long was I out for?"

"About twelve hours," he said. The waffles shot out of the petakiln onto a ceramic shingle. They were syrup-infused and ready to hand-eat.

The pad evaporated and I sat up to look myself over. I still had a good deal of my original body left. Almost nothing on the inside but my brain, about half my spinal column, and a length of small intestine, but my face, back, and all of one arm still had the original skin, and it still looked okay. I was considered lucky in that way, but what was luck to people like us? We got some sweet new organs and limbs, which allowed us to witness fifty percent more tragedy than our parents, who hardly even seemed like real things to us.

"I can smell those," I said, looking at Breach in prism mode.

"Knew you'd be hungry."

"Votes are in, B."

"What, I'm the best ever?"

I lay on the floor for a while, just zoning in the post-piz glow where you can still love things with all of your heart and you forget that you're just a scorched scrap of nothing blowing on the winds of time, etc.

"Oh damn," Breach said, and got down low with his hands over his head. Through the window over the sink I saw a drone swoop and hover among the gold-tipped sequoia. Those things had super-accurate heat indexers, and while we were mostly made of machine parts with the serial tones chipped off we could still be flagged and tagged. 
"It must have followed me back from my run."

"Goddamn, Breach. I told you not to go out in the damn day."

"Get the eff behind the couch," Breach hissed. I was still coming down off the piz high, and the moves my brain was sending to my bod were being pretty much completely ignored.

"Aw, damn." I looked over at Breach and he was crying through his one real eye and pointing at my chest. I looked down and saw a little pink dot of light which was the drone doing a sig test on me.

At this point I should, I guess, let you know that we had been trying to steer as clear as possible from anyone in an authority-type position since we bucked the new retirement mandate about seventy years ago. Which made the appearance of the drone and the sig test very not good. Back when we signed up for the life-enhancement program we were within five years of retirement, give or take. But when the government saw how well we did-how able-bodied and whatever we were with the new parts and syrups-they upped the retirement age to one hundred and twenty, which we were then not even close to. Most of us in the first gen of upgrades took off into the woods, because no way were we working for what amounted to a whole 'nother lifetime. We thought we were doing the sensible thing, but it turned out that the whole nation was against us. They didn't take well to the idea that we'd be living sweetly on their dime for a good seventy-five years at least, like this life is some sort of all-day amusement park pass, like we don't spend every shit-cutting moment regarding the ragged frailty of this final handful of years. As if that isn't punishment enough. Now we scuttle from squat to dim, minty squat, crushing deer droppings for seeds and watching for drones.

"Oh damn," I said. Breach put his arm up behind the sink and grabbed the bazoler that we hid there for emergencies. He went up into a combat pose and fired the bazoler at the drone. It fizzed and spit in the air and then nosedived into the Russian River. There was just a pinkish heart-shaped cloud where it had been hovering.

"That was extreme."

"We've got to go get it," Breach whispered, peering out the window.

"Get that thing and grind it to dust."

"And then eat the dust."

I hadn't expected that, necessarily. "Or just bury it?"

"No, we have to eat it."

I didn't think we should eat the drone, but we had to go find it before the detainer unit showed up. Breach put a couple guns into the holsters he'd cher- 
ried onto his bod and filled a thigh with inhalers. I looked around for the sack of memories but I couldn't find it.

"What are you doing?"

"Got to find that sack, B."

"You know what they will do to us."

"The only thing I ever take with me."

"I don't even have to tell you the heap of beeswax we're in."

"Never made any demands but for the sack."

"Okay," Breach said. "You look for the sack. I got to find that drone and bust it up. Don't be an idiot about this, okay?" And then he was out the door and down the rope to the river's edge.

I stood in the cabin alone for a minute. We'd lived there for eighteen years but you wouldn't know it. We'd given up on the idea of cleaning about fifty years ago, so the place, like all of the other squats we'd squatted in, was like a nest for rats, all chewed-up afghans and empty Puff bags and inhalers. The sack of memories was a sack full of memories-the last things I cared about in the world. They were obvious things. The kinds of objects you'd expect an old lady to wrap in a silk scarf and tie to her waist as she moves from place to place trying to stay ahead of the cops. Pictures of the kids crude-cut and pressed into a hinged locket, a vial of baby teeth. A wafershot of vids and pics and some old unreadable data. The wedding ring that won't fit on my finger now that my whole hand is made of flex pistons and nanoservos and gunk. A photo of me and Breach at Jade Cove, together and whole, before the Pookie Wars and Baseltech. Before the Seismic Event. Before Crooch. When we were a family, when our children were children. When we knew where they were, what they were doing.

Breach was hissing from the bottom of the ravine. I stuck my head out the window so I could see him.

"You gotta get out of there, Taffy." He wasn't even angry anymore, which was how I knew it was serious. He was standing in the water looking up at me and I could see the smashed drone between his legs, its wing bent and whipping in the current.

"I'm not leaving without the sack," I said only in my mind, I think, as I went on looking for it, tossing the couch cushions onto the floor like a person looking for something hidden inside a couch, which was the unlikeliest place for a memory sack but I was not doing my best thinking at the time.

I could hear Breach hissing at me, and then I didn't hear him, and then the silence got displaced by a raw and wicked rumbling. The roof of the cabin 
came off with a single snap and all of the loose papers on the sitting room table were swept up in the current of hard air kicked up by the rotors of the detainer unit, which was hovering right over my head. The unit tossed the roof down into the ravine like it was a potato chip. Right down where Breach had been. I looked over the edge but couldn't see him anywhere.

"Karen," someone said, which "Karen" was my name from a hundred years ago. I looked up through the open cargo hold and saw my father pointing the business end of a pulser at me.

"This isn't my fault," I said to him. He looked at me without expression. I tried another approach, but before I could finish my sentence he said, "It's time to come home, Karen," and a long segmented arm emerged from the hold and took me by the waist, and the guy projecting a hologram of my father turned back into an asshole cop, and pretty soon, you can probably guess, I was in a glass holding pen while a bunch of cops filled out forms at a narrow table that hung from the wall of the detainer unit.

"You had a good run, there." This was Pitsch, the officer who was saying stupid things to me from the other side of the glass while we traveled to wherever they were taking me. "What's it been? Sixty years? That's my entire life-and more! You've been in hiding for longer than I've even been alive. Think of it. Neat."

"If you think I'm saying a damn thing before you tell me where Breach is." "Breach?" He said, grinning. "You know Breach? Because we're looking for him, too. Can't find him right now but maybe you can help?”

"You're being a dick."

He looked at his hands, as though to doublecheck that he hadn't briefly turned into an actual dick. "Mr. Breachwood is still at large."

"Yeah, okay."

"Why did you stay in the cabin?"

"What?"

"You stayed in the cabin. Breach was not there when we arrived, but you were. Therefore, you stayed and he did not. And the question is."

"The question."

"Why did you stay?"

"Why did I stay."

"What was in that cabin?"

"I'm just slow," I said. "And when do we get to the jail?"

"Interesting," he said. 
"What."

"Interesting that you would say that, is all."

"So you're not taking me to jail?"

Pitsch looked at his hands again and I saw that he was communicating with another officer through some kind of ambient client. "There's no record of me saying that," he said. "And so but, yes, technically, we're not taking you to jail right now. We're going to CHET. Won't that be exciting for you to see where you were built?"

"I wasn't built there. My mama built me from all-natural stuff back in the buried age."

"Sure," Pitsch said. "Absolutely!"

"Will I see Breach there?"

Pitsch snorted. "You really think we've got him, don't you? You probably think he's right in the next room, huh?”

"I do," I said, because I did. I could sense him in the vehicle somewhere, in a room close by, even.

"Sure," he said, winking hard like a real douche. "You'll see him."

We docked on the roof of CHET and they wheeled me in a bubbled carrier into a dim, shabby-looking lab-type area that was mostly overstuffed couches and aerosol screens. A couple tiny interns poked at the air in a corner, presencing with a shadowy avatar from Kirkuk.

A woman with sideways hair and an ocular glided toward me on a standing stool. She looked at me for a while with that middle-distance detachment that meant she was really looking at some glossy HUD inside her brain, checking out my stats. Breach and I had disabled our HUDs a couple decades back just because, and I'd forgotten they were a thing. You really get to see the worst of a person when they're caught in the datastream. Their faces go slack and paunchy and they take on a smugness that's pretty hard to look at.

"And I see you are still in remarkably good health for a woman your age," she said, as though we'd already been engaged in some kind of deep convo.

"You tell me," I said.

"And you've managed to eke out an existence for all these years on this first-gen tech, which is-you are a testament to-this is, what I meant to say, impressive to say the least. Impressive, unforeseen."

I didn't say anything, even though she clearly wanted me to.

"And so. But we don't have-the one thing we can't get a clear picture of, at least remotely-is that wonderful and active mind of yours." 
"How do you know it's either of those?" I said, while a supercut of all the times I'd zonked myself throughout the years ran inside my head.

She smiled. She thought we were engaged in some sort of playful tête-àtête. And she was really digging it.

"I suppose we'll find out soon enough."

"So when do you take me to my cell and all that?"

The woman seemed to be completely thrown off by this question, as though it was crazy of me to think such a thing.

"I just want to go to my cell and sleep."

"I'm not sure I-do you think you're in prison?"

I told her she knew what they were after me for. I said things like, "retirement truancy" and "drones" and "manhunt." I told her to give me a goddamned break.

She stared at me with a slightly crestfallen-type expression, like she was watching a rabbit getting eaten by a dog or something. "My dear friend," she said. "Whatever it is you have thought we were up to all this time, it is not true. Your mind is far more valuable than any law you think you may have broken. We wanted only to observe you, to learn from you, to mine your experience for the benefit of future clients."

"You could have been a lot clearer on that," I said, not buying a word of her crystalline gibberish. She was just a woman in a white coat. She might as well have been a cloud of vaporized Oxycodone.

"Right now, you have the oldest brain on Earth," she said. "You weren't aware of this? You are the oldest person currently alive, at least as far as the DLIS8 defines 'life.' Because of this, you are an asset of inestimable value to our organization."

"Huh."

"So here we are," she said, not even trying to transition out of a response. "And with the aid of a Brocal Amp, we will create an indexable model of your entire neural architecture. Have you ever seen this before?"

I said I hadn't, because I liked the version of myself that this woman had conjured in her mind, of a wild scavenger streaking through the woods, stopping only to devour a possum raw or to force-poop into a hollow tree stump.

"And that will give us so much insight into who you are and how you got here and how we might better design the gear down the line. We will be able to see the world as no one alive-but you, of course-has seen it."

She turned and gently picked up a luminescent halo from the table. She held it gingerly with her fingertips and it shimmied there in the space between us 
like a coin tumbling into a wishing well. "When I put this on, you will feel a weight pressing down on you from above. You may feel dizzy, or nauseated, or both, but do not be afraid."

"Wait," I said. "What if I don't want this to happen?"

The woman paused for a second. "I'm sorry," she said, and then chuckled. "I just-do you know that it never even occurred to me that you wouldn't want this? I mean-why wouldn't you want to? You know, have all your thoughts and memories all gathered in one place, safe and secure-that's not, I don't know, desirable to you?"

"I didn't live thinking that anyone would be able to see the stuff I've done. Later, you know? On some screen, sitting back eating popcorn. I kind of just did whatever came to me at the moment. I don't think you're going to find any deep lessons."

"Oh, but we're not looking for lessons," she said, pretty serious. "We're looking for data."

I realized then that I didn't really know what she was talking about. I didn't understand what the stakes were. And if it really was just my thoughts she wanted, which hadn't risen above the level of finding piz and taking smooth dumps in decades, I guessed she could have them. It didn't matter. But I grabbed her wrist anyway and twisted it a little to throw her off guard.

"I want to see Breach when this is all done."

The look she gave me then was so shit-devouringly condescending that I nearly passed out. "Of course."

She reached out and put the thing on my head, and when she leaned in I saw the whitened ridge of a scar along her collarbone.

"How old are you?" I might have asked, because the halo thing was making me feel like a baby cat in a glass jar.

"Oh, we're probably closer in age than you think," she said in a cloyingly bashful tone that just underscored how close in age I already thought we were.

"Now," she said, looking not at me but at some streaming ribbon of data somewhere just behind the version of me she saw in her head, "here's where things become interesting." She went under the table and fished around in a cabinet, and I watched her and thought of Breach. I tried to imagine him sitting in the next room with a halo around his head, thinking of me at the very same time. We'd been together for a hundred and twenty years, and you'd think we could at least have gained the ability to sense each other's presence but I felt the same old doubt I always had. I was as certain he was there as I was that he was not. 
She sat up, holding something between her knees. "I want you to clear your mind as much as you can. I want you to imagine that you are a vessel. A transparent vessel, and a clear, warm liquid is pouring down into your core. You are both empty and full at the same time." As she said this she put the bag of memories on the table, carefully teasing open the throat and shaking everything loose, and as much as I tried to resist, to silence the riot in my brain, it surged like a tide and the whole room lit up. The woman closed her eyes and shuddered and the halo felt warm against my forehead. I remember that woman's hand clutching the vial of baby teeth, her seizures rattling the teeth in the vial. Bobby's warped molar. Josephine's eye teeth. A rust-tinged bicuspid that could have belonged to either. I had lost track of both of them. Or had they been the ones to turn from me? It was all so long ago and anyway, a century is too long a time to maintain the brittle rituals of a dynasty. The kids forgot about us and we lost track of them and I am pretty sure we were all better off. But Breach-I felt his presence clearly. I saw in my mind the way he looked when he came out of the OR with half a new body-that sense of relief mixed with fear, the fear of death that only accreted over time, leaving rings like a tree trunk. Every time they split him open to add a sim lung or kidney there'd be another set. I saw him with that tender expression and I ached for him the way, when you're sitting by a window and you see a dark cloud rolling in over the treeline, you sit there wishing for the first raindrops to pelt the glass.

I woke up with a fierce need to trace some piz. A big tank of it, one of those Russian deals with the condensation straws. The lining of my mouth was raw like coarse-grit sandpaper and I felt like I had a ghost testicle.

The woman appeared in the doorway of the room where they'd been keeping me. She had a little stick in her hand.

"God, what else do you want?" I asked.

"Oh, nothing at the moment." She seemed slightly hurt but took my response as an invitation to come in.

I sat up on the cot. "Guess I'll be on my way, then."

She smiled in a way that suggested I was being quaint for thinking I could ever leave. "I thought you might want to see the map we made of your brain." "Sure," I said. "Why the hell not."

She held the stick out for me. I took it from her and looked it up and down but could not make out what it was supposed to do.

"You just-breathe ... to unlock ..."

I took a breath. 
"No," she said, sitting down swiftly next to me, folding her crisp jazznet skirt beneath her. "First, just breathe out naturally. Don't think about it. The stick is designed to be used casually."

I tried to do what the woman said.

"Oh," she said, a red splash forming across her cheeks betraying a trace of embarrassment for me. "You really just-hmmm. This is hard for me to explain. You really have never used one of these before?"

I said I had used a stick like the one I was holding to diddle myself back in the time when I still had the necessary body stuff to mess with. She didn't seem to get what I was saying.

"Let me show you." She took the stick in both hands and sort of rubbed at it a little with her right thumb and instantly a light spidered out from the center of the thing, and we were surrounded by a massive rainbow-colored heightmap. There were huge spiky peaks and rolling valleys, and other areas that seemed to jut out at odd angles or melt into tear-shaped globs. The thing undulated and rippled all around us. A billion silvery strands that seemed to be lit from the inside, quaking and pulsing like a ravenous school of fish descending on a krillpod.

"This is my brain?" I said, which was a super-dumb thing to say because I knew it was my brain but it didn't look like anything I could ever understand as a brain. I thought it might have little movies I could watch or at least pictures of loved ones I'd forgotten about or who had forgotten me. How was I supposed to pick that out of a tide of ribbony light?

"Isn't it fantastic?" The woman cupped her hand over one of the peaks as it spiked and receded, showing her something about me that I probably didn't know myself.

"Where's Breach?"

"What?"

"Where's Breach. You heard me. You told me I'd get to see him."

"Oh," she said, "but you are seeing him. He's right here." She pointed to an area of the map where it looked like tectonic plates throbbing and shuddering. "Coming in rather strong, in fact."

I stood up and waded through the projected image over to the place she was pointing to. I crouched down so I could get a closer look. I wanted to believe that what I was looking at was the man I'd spent most of my life with, but it was all math. Some new language of light and time that I had no access to, a set of values that I could not crunch. I put my hand out like the woman had done and cupped at the air, but there was nothing. Not even a tiny point of heat against my palm to suggest that he was alive anywhere. 


\section{KraftMark}

Burtson was wading calf-deep in a foresty bog, following close behind the guide, a small man in fussy khaki fatigues. The diffuse, lame half-light of dusk punched out the detail of trees in the canopy, making them look like massive, buoyant cartoon mascots, maybe a clutch of parade floats for the dead. The color had run out of the world, and they still had not found Alan.

Every time he found a capsized landmine, Burtson was sure it was the last thing he'd see. The mines in this area were different from what he'd come to know through television, word of mouth, knowledge wafers, and childhood memory. The mines he remembered were crisp and angular. They radiated a colorful sphere of dread, and the dread was what kept people from going where they weren't supposed to go. It was a perfect system. These, though, were barely visible at the surface of the swamp. They had an animal quality, like squat snapping turtles, except that, instead of chomping an assworth of flesh from you, they would pound you with a bucket of bent nails going a thousand miles per.

"This looks the same as the last stretch," he huffed to the guide, light on breath from the struggle to drag his desk and accessories through the dense, sluggish undergrowth that pulled at his delicate loafers with each step.

Toshikazu did not turn, just shook his head, holding up one hand to beg for silence.

"Okay, okay. No talking. I get your drift. I can appreciate that. Meanwhile, we're walking around in circles, my slacks are, well, I couldn't even give them away at this point. I mean, they're toast."

Burtson had hired Toshikazu from an ad in the back pages of a monthly magazine for harpooning enthusiasts. Burtson was not interested in harpoons or the people who built and serviced them, but he liked the idea that he could be a collector of things. He liked the thought that he could be master of some great weapon-that he could lean toward a tablemate at dinner and explain how sailors hundreds of years ago managed to pierce the tough armor of a whale's hide without batteries or sonar or rocket fuel. Toshikazu's ad took up 
a quarter of the page-a crudely designed block of text accompanied by a lowresolution photo of a man hanging upside-down from a palm tree, aiming a blowgun at an off-camera target. The text read, "Taking care of loved ones can be a difficult and painful process. Kitano Toshikazu has trained in academies in Europe and Paraguay. He will treat your loved ones with grace and respect in their final moments, ensuring that they leave this world in peace and with dignity." Burtson did not want his son to feel pain when the time came to take care of him. He didn't want to be here at all, frankly, but he couldn't leave the task to the Kraftmark special ops team. They were brutal and immoral, especially Douglas Kincaid, the man Burtson had hired specifically for his ruthlessness. Rand had once shown Burtson a snapshot of his son's corpse. The kid had taken a bunch of half-naked friends for a joyride in one of the branded delivery trucks and crashed the thing into a transmission tower. It made the evening news statewide, which was as good as a death sentence. Rand and Burtson were standing side by side in the corporate restroom at KraftMark Headquarters in Delphine. Rand held up a blunt, smudgy polaroid in the blank wallspace at which Burtson was staring absently. "They gave me this instead of my son," he said. The boy's naked body was covered in cigarette burns. A pair of pantyhose yanked over his head made his face distorted and fat, as if he'd been stung by bees. There were a couple finishing nails buried in his chest, right through the nipples. Burtson didn't want that for Alan. It wasn't necessary.

They trudged for hours, nothing visible ahead or behind them but a massive, shapeless wall of treetoppish gray. Toshikazu surged forward deliberately, silently, through the thick water, waltzing through the spidered vines. Alan was out here, somewhere, broadcasting via shortwave radio the ingredients to the Whatever!?! Round, a new snack cake developed for KraftMark by Rand and his team for the fall "Fuck You, School!" lunch series. It had already outsold Molt.com's Wearables Serious Action Fruit Fudge in three of the test markets. The leaked ingredient list could sink KraftMark, though-everyone was nervous. One of the PR advisors, someone high up-he didn't know half the PR staff-had picked up the signal after getting a tip from the foreign bureau. So far, they'd contained the spread of the broadcast, but it was only a matter of time before it spread.

Something fell out of a tree. Something hard wrapped in something soft. It collided sloppily with a brittle tin roof from the burned-out settlement on the bank, voiding the night of birdsong with its clamor. Burtson crouched reflexively, breathlessly, hugging the rifle to his chest as he hunched in the muck. Toshikazu went on cutting through the water like nothing had hap- 
pened. This was pretty much the way Toshikazu operated. One morning, Burtson had awoken to the sight of a translucent orange scorpion perched on Toshikazu's face. "Hey man," Burtson had whispered, lightly gripping Toshikazu's shoulder. "Hey man, I don't mean to alarm you? But there's something on your face." Toshikazu opened his eyes, trained them on the insect, and quickly stuffed it into his mouth, chewing fast. All the while, his features were as calm and composed as when he was asleep. When he'd finished chewing he rolled over and his face went slack almost immediately, deep into another dream.

Scorpion on his face.

The swamp deepened without fanfare. The water rushed up to Burtson's chest, roiling up into the trough of his armpits, suddenly and outrageously cold. He smallened.

"What's this? How much deeper will this go?"

Toshikazu did not respond.

"So that's it? Once we're in the thick of it, you ignore me? You certainly had a lot to say back at base camp. You certainly had a lot to say during that impromptu session of baccarat. Remember the fleecing you gave me? Remember the noogie? I do. It's still right here, pulsing at the back of my head. Just like you were giving it to me still."

Toshikazu turned around abruptly. "Simmer down."

"What? What was that? Could you repeat yourself? I could hardly understand what you were saying-you know why? Maybe because you were actually using language."

Toshikazu launched a stare, something hard and remote, so that Burtson wished he hadn't said anything. "You want to know why I don't talk to you out here? You're an embarrassment."

"No disrespect? I know a certain ball team, a well-known team of young black men, a team of men that I own, all of whom would disagree with you."

Toshikazu paused by a felled, half-submerged tree and climbed silently onto the warped trunk. "Look there."

Up ahead they saw a tiny square of light flickering in the dark humidity.

"That's it? That's the stronghold?"

"No. That's a trap."

"How can you tell?"

Toshikazu hefted a small rocket launcher to his shoulder, aimed, and fired a purplish, whiffled sphere, which made a bright howling noise as it tore through the black shrubs. The house from which the light emanated lit up for 
a moment from the incandescent spray of the rocket-it was a boxy, pitchedbeam hut, nailed in with tin sheets and old traffic signs. Then it exploded in a wild, thudding ring of gas and wood chips.

Burtson fell back without realizing and got a mouthful of swamp. The inside of his skull went green and bright.

He floated in place on his back, his jacket snagged on a broken branch. Toshikazu crouched at a distance, poking carefully at the rubble with a twig. Burtson struggled briefly to uncouple himself from the branch but he couldn't reach far enough behind him to unhook his collar.

"Please don't do that again," he said when Toshikazu finally waded back to release him. "Please don't blow anything up. That's not necessary."

"There were bodies in the rubble."

"Come again?"

"Neither of them was your son. Let's keep going."

Burtson crawled up the outcropping and poked at the charred hunks of wood with a long branch. "Hey could you-I mean, I'm just wondering-you said there were bodies? In that rubble? The rubble that you, essentially, well, caused?"

Toshikazu was off already, his arms lifted above his chest as he sank deeper into the swamp. Burtson tugged at the cord-his desk was wedged between two half-submerged root balls. He quietly conjured a plume of regret for having overpacked.

It was dark, so dark that even the still things seemed to heave and quake, their outlines no longer registering-the border between the objects and the indefinable world beyond hopelessly blurred and blackened. The night always made him think of Alan, of the terror the moon brought. Marion insisted Alan sleep in their bed as a baby instead of in a crib, so that when he grew too big to fit, he was incapable of sleeping on his own. In order to wean Alan from the master bedroom, Burtson stayed awake night after night, accompanying the boy through the nameless hours as they advanced and ebbed with monolithic fury. He read the boy to sleep, literally bludgeoning Alan with language until the words took him out of commission. He burned through all of the books on the boy's shelf, and when he'd read them again, and through a third time, he began to read from his own collection, books about power and influence, how to broker a deal, books on military strategy, books on the construction of factories, of networked enterprise systems, of team leadership and supply chain management, of ancient battleships and the grayed, stoic men at their helm. He read until his voice went flat and wisped, until the thought of words 
was so unbearable he couldn't read any more-like there was a man standing behind him, stuffing his mouth with dry paper towels each time he flexed his jaw. He'd gag and spit, unable, suddenly, to concentrate on anything else. By the time dawn flickered, he felt nearly drowned. He longed for the moment when the light through the window finally overpowered the light from the boy's nightstand, but when it came, he couldn't help feeling that something was being taken from him as well. Those hours he shared with Alan were his-those interminable vigils during which he could truly believe that he was keeping the boy from something.

Now the boy was reading on his own-material he was never meant to read. Now, in this part of life, Alan was doing all the talking. What had happened? How had the boy taken Burtson down like this? He couldn't remember when Alan lost his terror of night. It must have been slow, gradual, imperceptible as evolution itself. But suddenly the boy was out there, acting on his own recognizance. Burtson had expected rebellion, sure. But this betrayal-he could very well have handed the company over to Alan at one point. All the kid had to do was hang in there. Now he was blowing the secret to the world's most successful branded snack cake?

Toshikazu set up a tent on the bank of the swamp, next to a hideous decaying trunk. The tent was low to the ground, so you had to get on all fours to enter. It was barely big enough for the two of them.

"This is how they do it these days?" Burtson said, running his finger along the tent fabric, which was gauzy and light, right up against his face.

"Keeps in the heat. Keeps a low profile."

"Last time I camped, the tents were canvas."

Toshikazu turned over.

"You have anyone?"

Toshikazu opened one opalescent eye. "Once."

"Really? A wife?"

"Yes."

"Tell me about it." Burtson turned, propped himself up on an elbow. His head made a zipping sound against the tent fabric.

"It's not something you want to hear."

"Sure I do."

"No."

"Come on-we're out here-might as well burn off the night."

"You asked me, and you are only American," Toshikazu said, breathing lightly, "so I will tell you what happened. It's an interesting story. My wife and 
I moved to America shortly after we married. We didn't know much about the country. We just flew to America. It was something we both felt we needed. We didn't have a plan-we just rented a car at the airport and started driving. We drove until it started to snow, and when it snowed so hard we couldn't see, we turned off the highway into the parking lot of a family-style restaurant. The restaurant was in a shopping mall, which was surrounded by deep, manmade moats. It was difficult to navigate through the parking lot of this mall, because of all of the lakes and moats, the man-made waterways, what have you. The whole parking lot was blanketed in snow. We drove very slowly, hoping to navigate by feel. I thought about our old house, how I had rigged up all of the lights inside to turn on automatically whenever we were away, to give the impression that we were still home. I thought about those lights, coming on at dusk in the empty house. It occurred to me then, and never before, who was I creating this display for? Who were we trying to fool? I thought too hard about this, because I drove us into one of the man-made lakes. There was a horrible grating noise as the car plowed through the ice ringing the lake's perimeter. The car floated out into the middle of the lake, sinking slowly as it did. I managed to get out of the car through the driver's side window. I climbed on top of the car. It was so quiet out. I could hear only the snow falling on the parking lot. It was loud, like the cheer of a thousand fans at a soccer match. But there was no other sound. The city was choked off."

"Your wife-"

"She was caught inside. I was on top."

"But couldn't you-I mean could you not help her?" Burtson conjured the words as a scold, but they emerged more plea-like.

Toshikazu blinked twice. It was the first time Burtson had seen him do this. "I don't know. I felt like only one of us was going to make it. I might have let her die there."

"That's nonsense. You wouldn't be able to-to do that. No one could let someone die like that."

"Now that you know what I am capable of, I would like to get some sleep." Toshikazu drew a section of sleeping bag up over his head and turned over, facing away from Burtson.

The next day they had to climb a sheer cliff, which took longer than it might have if Burtson had not taken along his desk, which was heavy, even though it was only imitation mahogany. The rolltop kept opening up, jettisoning a cloud of yellow legal paper, which tumbled wildly, scatteringly down the face 
of the rock. Every time this happened, they had to secure the desk to the cliff face using spikes and rope, and Burtson had to climb down and retrieve each piece of paper.

In the afternoon, Toshikazu grew tired of waiting and picked up a healthy pace. He set up camp along the ridge, sautéing mushrooms while attempting to zero in on Alan's transmissions using a squat red crank radio. Burtson threw a leg over the edge for balance and asked Toshikazu, "A little help?"

His face was purpled and splotched, spattered with dirt and mucus. His hands were trembling so that he could barely grasp the nylon cord. Toshikazu yanked the desk up over the ridge while Burtson collapsed next to the fire. His eyes stung with hot sweat. He could barely open them-he had to struggle, like at the end of a dream when suddenly things go dark, and it takes all of one's strength to move inches.

"Just set it up over there," he said, motioning lamely to a dirty clear spot by a stand of trees.

Toshikazu put the desk down and returned to the fire. "You made me burn the mushrooms," he said, staring evenly into the smoldering pan.

"Good," Burtson said. "I don't go for mushrooms. Humans weren't meant to eat dirt."

"I'm afraid that's your only choice tonight."

Burtson palmed the dry soil before him. He bunched it up, cupping the mound in his hand, as if it were a breast.

"I still don't understand why you would let her die like that."

"I don't know that I let her. It's just that I didn't let her live."

Burtson turned over. At the horizon, the sky was a raging, red cloudmass, like the throat of an old desert lizard. But up above, he could see stars punching through the navy impossibility of outer space. "I want to offer him a chance. Just one."

"Your staff will kill him if we don't."

"I know, I know. I'm just thinking that I could ship him off somewhere. Put a sombrero on him, a false mustache, send him down to Argentina. Isn't that where all the Nazis went after the war?"

"They'll find him. There is no Argentina."

Toshikazu scrolled through the stations on the shortwave. There was a popping noise, and then a sort of phased, intermittent tone, and then a voice. At first it seemed to be running backward, generating a childlike nonsense language. But Toshikazu homed in on the voice, setting the dial so that it was 
crystal clear. It was Alan, listing with a patient and even tone the ingredients of the Whatever!?! Round.

"Dextrose-okay, listen carefully to this one. I'm going to try to pronounce it and then I'm going to spell it out, because I don't really know how to pronounce this one. 'Maleodexetrine sulfate'? Does that sound right? M-A-L . . . Apparently, you inject 200 ccs of this substance into the slurry-E-O-D ..."

Burtson crawled over to the speaker of the shortwave and held his ear very close. It was a telling posture he assumed Toshikazu would find pathetic. Burtson would have to agree, if he were watching from anywhere outside his own body. Unduly and egregiously sentimental. But the voice was arresting, dark and melodic, possessed of an assuredness he hadn't imagined Alan capable of. He could hear, in the brief intervals between breaths, or in the throat clearing, or during the pauses to keep the microphone from falling over in the wind, a tuneful, barely perceptible cough, one Burtson knew from those early years, the pre-KraftMark years, in which he was working late into the nights, high up on the twenty-third floor of an office building that might as well have been the bridge of an enormous spacecraft adrift in deep space, all the city's lights like distant stars, his son the inhabitant of a planet he could barely remember. He'd come home and kneel at Alan's bedside to watch him sleep. The boy would twitch occasionally, shifting in the sheets, making that coughing sound, like the cough of a vole or some other burrowing rodent, an animal that wanted nothing more than to go unnoticed.

"He's transmitting from a mountain top," Toshikazu said, rising to scan the horizon.

"Know what?" Burtson said. "I'm fine with this. I'm good. He's not doing anyone any harm. He's just crazy. Let him stay here, that's what I say. Let the crazy kook live up here on the mountain. He's not hurting anybody. Let's head back to base camp."

Toshikazu looked back sharply. "Don't do this. Allow your son the dignity of dying by your own hand. Don't let them do it. They'll tear open his nutsack and scrub out his genes with a wire brush. They'll staple his hands to his buttocks and throw him out of a helicopter into the main square of some remote village. You want that for your son?"

"Nobody wants that."

"Pick up your things and let's go."

Burtson heaved himself up, scraping open a kneecap on a toothsome mound of jagged black rock. He wished for an aerosol can of Secret Skin, the kind he used to spray over Alan's playground injuries. He attached the nylon cords 
from the desk to his harness and lurched forward, following Toshikazu at a lame, distant pace.

As the night overtook the sky behind them, pressing at their backs like a suffocating tarp, Toshikazu spotted a silhouetted figure seated on a ridge. $\mathrm{He}$ crouched behind a stand of weeds, pointing the figure out to Burtson, who couldn't make anything out. It was all just jaggedness and splinters against the red flush of the dying sun.

"This is the end of my job," he said, squinting at the distant point.

"How do I do this?" Burtson's shoulders started to gyrate uncontrollably. He crossed his arms, pressing his palms against his ribcage, but he couldn't hold back the twitching muscles that hijacked his torso.

"Just like we did in the training sessions." Toshikazu slipped the rifle from its polyester case.

"Those were dummies. Those were stuffed dummies."

"The human body is really just a moist, complex version of those dummies." He loaded the magazine and powered on the infra-red sight before handing it to Burtson, who held it like a candy bar.

"I think you're a little out of line."

"Nobody on this mountain is anything more than a brilliantly designed sack. The only distinguishing feature is what others have crammed inside us over time."

"An interesting take. I wonder what your wife would have thought about that."

Toshikazu put his hands in his pockets and stepped away.

Burtson held the rifle in front of him, as far from his chest as he could reach. "If you don't mind, please remind me how to aim this thing. I'd like to get this over with."

"Figure it out. Figure it out your goddamned motherfucking self." Toshikazu turned away and dropped down from the cliff edge in a swift, deliberate arc.

Burtson hefted the rifle. It was all trigger, all form factor; it fit into the crook of his arm like a newborn. There was a scope, larger in diameter than a baseball bat, and it looked like it needed to be turned on. He turned it over in his hands again and again, but it never made any more sense. He decided to give it a shot anyway. There was a sort of raised fin on the nozzle, so he used this for aim. He heard Toshikazu behind him. "That's not-look, you're going to hurt yourself." 
He felt something surge up in him, something heavy and luminescent. It rose up in his chest cage, topping off at the back of his throat. It was a feeling he remembered not in his conscious memory, but in the larger memory everybody shared, the memory of the flattened, husky humanoids who knocked around in squat forests in the years before time mattered, making a dim impression in their respective tribes by killing up whole herds with insensate panache. The feeling made sense-he was aware, fully, maybe for the first time, of the extent of his body's capabilities. There were no more illusions-he knew he was not a superhero-he knew he could not burst through a brick wall or kick a man's balls up through his chest. It was a sober, rational summary of what he could do with his body.

Burtson lined up the fin with Alan's figure and squeezed the trigger impulsively. The rifle was surprisingly quiet. Alan turned, startled, as a congregate of broad leaves exploded in the air over his head. "They're here," his son shouted into the microphone. "This is it. I'm not going to make it out of here. They won't leave until I'm taken out. Don't let the recipe die-keep it going. Keep it-"

Burtson fired again, and a third time. Alan jerked backward. "Holy crap," he said. "Holy crap." He took three stumbling steps and then crumpled. Burtson wished Toshikazu had stayed; he felt a queer pride click into place somewhere inside, but quickly he thought better of it. Shooting your son, it was a private thing, composed of a sweet, crushing sense of impossibility. You didn't want to share it, in the end.

Burtson dropped the rifle and sat at his desk, where Toshikazu had left a Post-it note with his billing address. He took his cell phone from the top drawer and tried his wife. Somehow, he got a ringtone. A woman answered the phone in another language. "Hello? Marion?" he said, and the voice replied in a fluttery, unrecognizable tongue. Realizing it was a stranger, he whispered, "I just shot my son," feeling each word turn in his dry, dirty mouth like rocks in a tumbler. "I took aim and I shot him. Has that ever happened to you?" The voice erupted again, and then died off sharply. He thought the woman might have hung up. "It's a thing you remember," he said. "It might be the only thing you really remember. You take back what you've given. It goes against-it's a powerful thing, what you've done when you do that." He stopped when he heard the dead tone of the disconnected call. He wasn't sure if the woman hanging up had hurt him more than the sight of his son slowly folding up into a compact hump on the horizon. He was sure he'd know later, on the plane, speeding ridiculously over a charcoal-dark, midsize, failing industrial 
hub. When he got farther away from the jungle, he thought, he'd be able to measure the two events, hold them, one in each palm, and divine to himself the thing he felt worst about. 


\section{Walden Galleria Prayer}

Our Father, who aren't in Heaven. Hallowed be thy name. Our kingdom come. Our will be done. On Earth as it is in heaven.

Give us our daily bread, and forgive us our trespasses, as we forgive others, for the kingdom, the power, and the glory are yours $\mathrm{O}$ mighty Father, forever and ever.

Actually, I don't think that's quite how it goes. The sequence may be slightly out of order. In fact I am pretty sure I got certain parts very out of order and certain other parts I took from other prayers possibly. But the feeling was there. I felt, more or less, the same upward surge, that overwhelming sense of hope that you muster when you recite a prayer you know by heart. This prayer that I am reciting now at least hovers in the vicinity of a true prayerfulness, am I right? And I am assuming that is what matters to you, O Lord, correct? The feeling more than the words? Because a man can go through his whole life knowing all the right words-the right name for every last thing in this world-and still be a very corrupt man. Isn't that right? I'll take someone who knows the feeling of things. A person who appreciates the $w h y$. That's what's truly important. Unless it's not, O Lord, in which case I am assuming that at this point it is too late for me to go back and re-learn everything I know or once knew about you. But let me say that, in my humble opinion, I prefer the version of you that goes with the feeling rather than the accuracy. That's just who I am. A fallible man, infinitely small in the great scheme of things, bleeding from the face in a mall parking garage, hoping the men don't come back, praising your name and trying very hard to bliss myself out on your glory in the midst of these crackling seizures of pain.

Lord, please don't let the men come back. Holy Father, please let them be done with what they came here to do. Let them have found whatever they were looking for-the cash and whatever else-and let them be on their way to their cursed homes. Holy Mary, mother of God, your grace is sufficient for thee. I am not worthy to receive you, but only say the word and I shall be healed. 
I know, Lord, that I have not prayed to you in many years. I know that it is not fair of me to suddenly begin praying to you right now, only after the two men have done their work on me and left me on this blacktop by the vending machines. If I'd prayed to you regularly, every day, spreading my devotion out evenly through normal time, I imagine you'd be slightly more inclined to help me out here. In fact, if I had been the kind of person who prayed I imagine you would probably not have let me get anywhere near this mall right now. You'd have made sure I was home with my family, asleep and dreaming. I am pretty sure that I can't just spontaneously well up with devotion and spend it all in a single white-hot burst immediately after two men held me down and sprayed me in the face with a high-pressure hose and then the one of them whipped me with the side view mirror he busted off my Kia Cadenza while the other one took everything out of my pockets and then stomped on my Achilles' tendons until both my ankles broke or at least they now feel really quite broken. That would be like only buying one lottery ticket ever and having it be the winning ticket. I know. I have no right to be asking for your help right now and yet here I am, unable to really feel my face or lift my left arm and certainly not able to walk, not after the one man and his stomping again and again on my Achilles' tendons until I could no longer tell where the pain ended and the rest of me began, praying with all that is left in me for you to reach down and scoop me up in your big radiant hand and fill me with life, just this once, through Christ, our Lord, amen.

Was that the sound of the men coming back? I heard a sound like the squealing of new sneakers on wet pavement. Please, O Lord, just this once, reach down. Reach down and restore me with the cool blue light of life. As a boy I took religious education on Sunday mornings, and we were instructed on the first day to draw what we thought God looked like, and all of the children in the class drew pictures of bearded men seated on clouds, but my picture showed a fist made of pure light punching through time. The chaplain called my parents into his office at the end of class and showed them the picture as evidence that I was not ready to learn about God. But was that true, O Lord? Because how can we know what you look like, and how else could one portray your power except as the punching of time itself? In my head this was the ultimate expression of your glory and might-it still is!- -and I was confused when my parents sent me to my room for the rest of that Sunday. But my father left my mother just a few years later, proving my point.

That sound just now? That was not the men returning. I do not know what it was but it was not the men returning and O Lord, almighty God, 
thank you for sparing me from a second punishing attack. I am not worthy to receive your grace, but I will gladly accept it now in my time of need and will, if I make it out of this parking garage, return this holy gift through good works. All kinds of good, durable works. The first one of which will be working things out with Eleanor. Clean-slating that whole mess. Apologizing for everything, even the things that do not technically require any kind of apology. Letting go of my resentments of her. I am not saying it is going to be easy. And also, not for nothing, just to be clear, but the making amends to Eleanor comes after the horse business is done, but I am assuming that you know that I will never again in my life, assuming you allow me to live, enter an Off-Track Betting facility or even look one up on the Internet, so I am not even considering that the first thing I will do. That is more like Thing Zero, already a done deal. But I see you in your position, deciding whether or not to save a man who has forsaken you with great gusto over the years. You have to decide whether to be merciful and to let me live another day. So many times, O Lord, you have let men go who did not have pure hearts. I am going on a hunch here but it is based on a great deal of real-life experience. These men have made you promises, and you have held up your end of the bargain, only to get burned. And what makes this particular situation any different except for the fact that you have line-of-sight directly into the center of my soul and you know that I am telling you straight-up that if you allow me to live and walk again I will adopt a special-needs child from Honduras and join the board of a non-profit organization that builds irrigation tools for Sudanese villagers. I will become a wild and passionate advocate for you. I will freak on the streets for you, and I am ready to be every bit as in-your-face about the good word as you want me to be. I will make people uncomfortable and they will despise me at first, but they will never be able to forget the things I will tell them. They will never forget the words on the posters I will hand-paint and carry with me on the subway. The words will get all stuck up inside them like a plume of tiny glass shards. I will jailbreak their hearts and do things to their insides that will change them forever. All of that energy I have expended on the horses these past five years, O Mighty Lord, I will redirect toward the spreading of your message to those who need it most, which is most of the people I know anyway. Which is not to say that I plan to spread the word only to people I know. That would be too easy. That would not be a fair trade for your saving of my life right now. I am just guessing about that, but I probably need an answer on it relatively quickly. I can no longer feel the left side of my body at all, and it is like wasps have hived in my ankles. When I open my eyes one eye sees 
the opposite wall of the parking garage and the other eye sees a sort of pulsing torrent of blood with little bubbles skimming across its surface as it soaks into the blacktop, black on black.

I am not trying to tell you what to do, Lord, but I have this idea. If you wanted to. If you were feeling generous and trusted me to do what I've promised. As this is a parking garage, you could simply have a car drive up the ramp right now and see me laid out by the vending machines, face down in a pool of blood. Whoever is in the car, assuming that they are reasonably good people, will surely take over from there and call for an ambulance. Does that seem fair? All you'd have to do, O Lord, would be to find some person out there on the highway at night and persuade them with your might to take Exit 52e off the Thruway and enter the parking garage. And then they could take over from there. I am pretty sure that the whole mall is closed, but perhaps you could make this person hungry enough for a plate of Jalapeño Crusters that they might pull off the highway just to see if Sam's Salt Bun is still open, because in my opinion they do make a very good cruster. I imagine that would hardly take any effort on your part at all. Just a little push. What's the cost of that to you? It must be like a millionaire buying a fifty-thousand-dollar car.

So that's just a thought. Just something I'm putting out there for your consideration. Humbly.

Our Father, who aren't in Heaven. That can't be right.

Our Father. Who. Art.

In heaven.

How is it that the two men had a power washer with them? And how did they operate it in a parking garage late at night? I am just asking that question to the cosmos, O Lord. I don't expect an answer. I just did not know that a person could carry around a device that shoots water out of a high-pressure nozzle. What's the practical application of a thing like that? Why would someone need such a thing, if not to tear away the flesh from another person's face? I speak from experience when I say that these devices, if they are legal, should be made illegal. I feel like my whole head is just like a platter of cold cuts. Any device that can do this to a person should be outlawed.

Is that it, O Lord? Is this a case of, "to everything there is a purpose," where you have disfigured me with this device-wisely employing the men as your proxy, of course-so that I would rise up and call for a ban on portable power washers? And that my face, which I am pretty convinced at this point is just a featureless gourd, will convince even the lobbyists to back down in their attempts to keep these portable power washers on the market? If this is your 
plan, then so be it. You are calling the shots here and I will follow through to the best of my ability. But I would not be completely honest with you if I didn't say I thought this plan was a little harsh, and I know that you value honesty above all else. This whole prayer, in fact, has been a straight shot of honesty so far, even when it has painted an at times somewhat unflattering picture of me. So I have to say that, if I were in your position, I would be pretty on-the-fence about putting me through something like this. Having no face. Maybe never walking again and maybe, probably, something even worse. Just to prove a point about faith.

Or something. I suppose I don't even really know what your point is, $\mathrm{O}$ Lord. Maybe it's something I don't even know about. If that's true-if this is all about something I've been doing wrong without actually knowing I've done the thing wrong - how is that fair? You never gave me a chance, Lord. You never did. You put that OTB station in when they closed down the Rite Aid and you made the boys take the Mixed Martial Arts class in the building across the street, and you positioned the windows so that I could watch the kids whale on each other while I pored over the charts. You got me in deep and held me there, Lord. You peppered my losses with those little spikes. Those little windfalls. You kept it going. I see now. I see your plan. You kept it going, O Lord. You tested me. You tested me, Lord. Christ. You tested me and I failed. Right?

I saw the men follow me out of the parking lot of the OTB on Bristol Ave. in a brown Lexus GS. I went to the mall because I'd overheard someone saying that, once. "You're always safe at the mall," they'd said. Was that you, O Lord, or one of your earthly angels putting that idea in my head all those years ago to effectively seal my fate?

Two men in white sneakers and baggy cargo pants. Older men with glazed orange skin and buzz cuts. Tiny golden hoop earrings. They wouldn't even speak. Wouldn't dignify the task with an epithet or two. They could have been Russians, for all I know. They just took out the power sprayer and steadily worked it back and forth, back and forth. Did the things that they did next, which I can only remember the sensation of them tugging at my clothes, but as if I was deep underwater. The two men breathing heavily, not saying anything, not to me. Not to each other.

And then they were gone.

Our Father, who art in heaven. Hallowed be thy name. Thy something something. Thy will be done.

The church my parents took me to was just a brick building with folding chairs and a portable altar. Previously a convenience store. Soon to be a differ- 
ent convenience store. Some rogue offshoot from the Catholic Church. They were burrowing hard into the final few years of their marriage in a furtive attempt to explain away what was wrong between them as a flagging of the spirit. Fishing for the tear in the fabric of their commitment when it was all tear.

There was a song they would sing, though. I can bring up the melody but not the words, but we would stand together and they would belt out the verses, tuneless and brash, struggling to hit the upper register, but struggling, going for it, shamelessly calling out for a higher power. And my mother would run her fingers through my hair, and her bracelets would delicately chime, and if that is the time when I felt closest to them, O Lord, why can't I remember the words to the song?

You can't break a person's Achilles' tendon. You can't break it.

And He will raise you up on eagles' wings

I think this is it. The song they would sing.

And He will raise you up on eagles' wings

Bear you on the ... hmmm ... of ... time

Make you to shine like the sun

And hold you in the palm of His hand

The names of the horses, also a kind of prayer. Diamond Dancer, Obsidian

Dream. Rhiannon, Graceland, Teardrops and Rose.

The Sky's the Limit

Violent Storm

Graceland

Graceland 



\section{Books in the Series}

\section{1st Century Prose}

Series editor: Matthew Vollmer, Virginia Tech

The 21st Century Prose series celebrates varieties of forms-of prose that breaks the rules, bends conventions, and reconfigures genre. The books in this series engage playfulness and experimentation without sacrificing accessibility and readability. The voices represented in the series come alive on the page through prose that is at once down-to-earth and also a reflection of an artist at home with his or her improvisations. Life-affirming but convention-defying, the language in these books strives to be both groundbreaking and readable. The 21st Century Prose series listens for and endorses voices that have been marginalized, reports from zones-physical and spiritual and emotional-from which we have yet to hear. Kind-hearted renegades. Things we can't describe but that leave us pleasantly puzzled, forcing us to say, "listen, just read it."

Books in the Series:

Full Metal Jhacket

Matthew Derby

\section{A Heart Beating Hard}

Lauren Foss Goodman

Settlers of Unassigned Lands

Charles McLeod

American Homes

Ryan Ridge 